\section{OAK RIDGE NATIONAL LABORATORY}

MARTIN MARIETRA
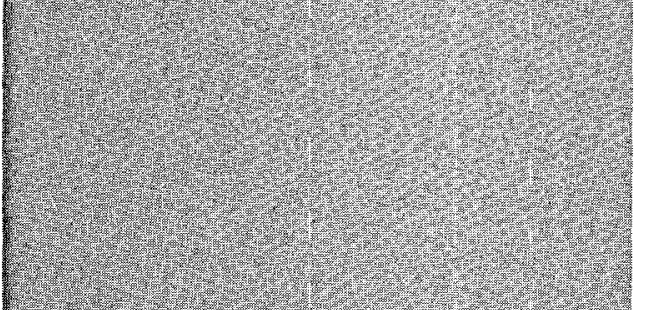

\title{
ENVIRONMENTAL RESOURCES OF SELECTED AREAS OF HAWAII:
}

\section{ECOLOGICAL RESOURCES}

\section{\%}

by

Carl C. Trettin, Virginia $R$. Tolbert, Anthony T. Jones, Craig R. Smith, and Adrianus J. KaImijn

Robert M. Reed, Project Manager

\section{MANAGED BY}

MARTIN MARIETTA ENERGY SYSTEMS, INC.

FOR THE UNITED STATES

DEPARTMENT OF ENERGY 


\section{DISCLAIMER}

This report was prepared as an account of work sponsored by an agency of the United States Government. Neither the United States Government nor any agency Thereof, nor any of their employees, makes any warranty, express or implied, or assumes any legal liability or responsibility for the accuracy, completeness, or usefulness of any information, apparatus, product, or process disclosed, or represents that its use would not infringe privately owned rights. Reference herein to any specific commercial product, process, or service by trade name, trademark, manufacturer, or otherwise does not necessarily constitute or imply its endorsement, recommendation, or favoring by the United States Government or any agency thereof. The views and opinions of authors expressed herein do not necessarily state or reflect those of the United States Government or any agency thereof. 


\section{DISCLAIMER}

Portions of this document may be illegible in electronic image products. Images are produced from the best available original document. 
This report has been reproduced directly from the best available copy.

Avallable to DOE and DOE contractors from the Office of Scientific and Technical Information, P.O. Box 62, Oak Ridge, TN 37831; prices avallable from (615) 576-8401, FTS 626-8401.

Avallable to the public from the National Technical Information Service, U.S. Department of Commerce, 5285 Port Royal Rd., Springfield, VA 22161.

This report was prepared as an account of work sponsored by an agency of the United States Government. Neither the United States Government nor any agency thereof, nor any of their employees, makes any warranty, express or implied, or assumes any legal liability or responsibility for the accuracy, completeness, or usefutness of any information, apparatus, product, or process disclosed, or represents that its use would not infringe privately owned rights. Reterence herein to any specific commercial product, process, or service by trade name, trademark, manufacturer, or otherwise, does not necessarlly constitute or imply its endorsement, recommendation, or favoring by the United States Government or any agency thereof. The vlews and opinions of authors expressed herein do not necessarily state or reflect those of the United States Government or any agency thereof. 


\title{
ENVIRONMENTAL RESOURCES OF SELECTED AREAS OF HAWAII: ECOLOGICAL RESOURCES
}

\author{
C. C. Trettin ${ }^{1}$ \\ V. R. Tolbert \\ Anthony T. Jones ${ }^{2}$ \\ Craig R. Smith ${ }^{3}$ \\ Adrianus J. Kalmijn ${ }^{4}$ \\ Robert M. Reed, Project Manager \\ Energy Division
}

March 1995

${ }^{1}$ Environmental Sciences Division

${ }^{2}$ Consultant, Vancover, British Columbia

${ }^{3}$ Consultant, Kailna, Hawaii

${ }^{4}$ Consultant, Encinitas, California

\section{DISCLAIMER}

This report was prepared as an account of work sponsored by an agency of the United States Government. Neither the United States Government nor any agency thereof, nor any of their employees, makes any warranty, express or implied, or assumes any legal liability or responsibility for the accuracy, completeness, or usefulness of any information, apparatus, product, or process disclosed, or represents that its use would not infringe privately owned rights. Reference herein to any specific commercial product, process, of service by trade name, trademark, manufacturer, or otherwise does not necessarily constitute or imply its endorsement, recommendation, or favoring by the United States Government or any agency thereof. The views and opinions of authors expressed berein do not necessarily state or reflect those of the United States Government or any agency thereof.

Prepared for

U.S. Department of Energy

Oak Ridge Operations Office

by

OAK RIDGE NATIONAL LABORATORY

Oak Ridge, Tennessee 37831

managed by

MARTIN MARIETTA ENERGY SYSTEMS, INC.

for the

U.S. DEPARTMENT OF ENERGY

under contract DE-ACO5-84OR21400 
[blank page]

b

and a and 
LIST OF FIGURES $\ldots \ldots \ldots \ldots \ldots \ldots \ldots \ldots \ldots \ldots \ldots \ldots \ldots \ldots \ldots \ldots \ldots \ldots \ldots$

LIST OF TABLES $\ldots \ldots \ldots \ldots \ldots \ldots \ldots \ldots \ldots \ldots \ldots \ldots \ldots \ldots \ldots \ldots$

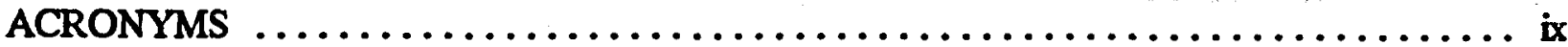

1. INTRODUCTION $\ldots \ldots \ldots \ldots \ldots \ldots \ldots \ldots \ldots \ldots \ldots \ldots \ldots \ldots \ldots \ldots$

2. TERRESTRIAL ECOLOGY $\ldots \ldots \ldots \ldots \ldots \ldots \ldots \ldots \ldots \ldots \ldots \ldots \ldots \ldots$

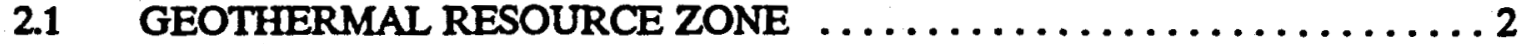

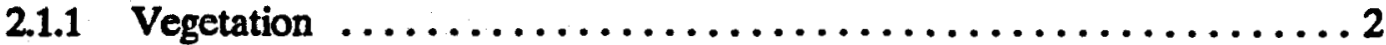

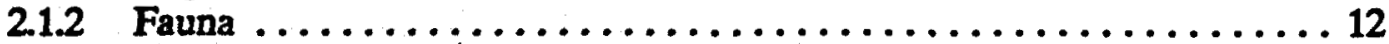

2.2 OTHER STUDY AREAS ON HAWAII $\ldots \ldots \ldots \ldots \ldots \ldots \ldots \ldots \ldots \ldots \ldots$

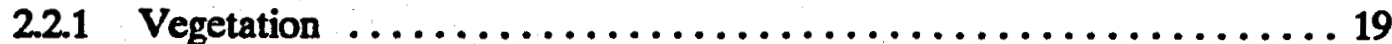

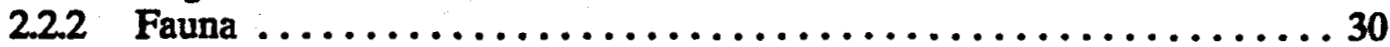

2.3 STUDY AREAS ON MAUI AND OAHU $\ldots \ldots \ldots \ldots \ldots \ldots \ldots \ldots \ldots \ldots$

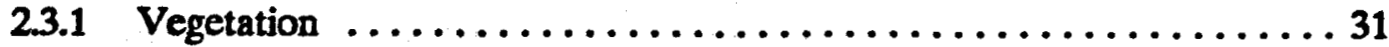

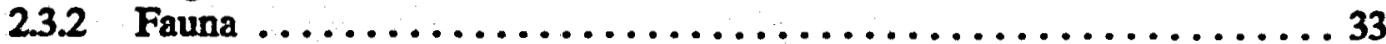

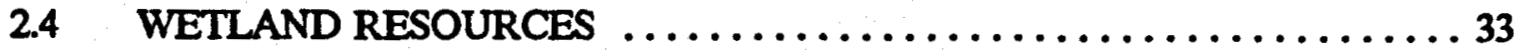

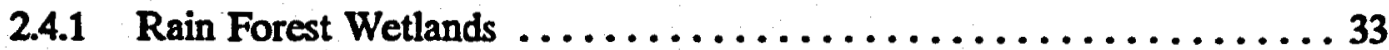

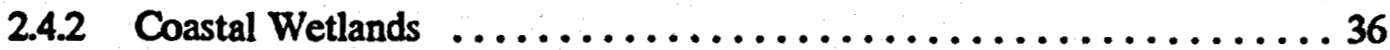

2.4.2.1 Wetlands in the vicinity of the Geothermal

Resource Zone, island of Hawaii ............... 37

2.4.2.2 Wetlands in the vicinity of the study area, Maui ........ 37

2.4.2.3 Wetlands in the vicinity of the study area, Oahu ........40

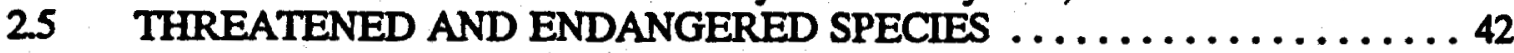

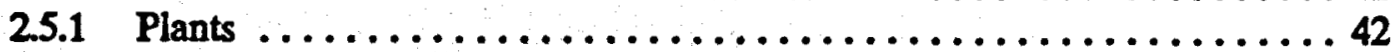

2.5.1.1 Geothermal Resource Zone and other study areas in Hawaii . . 42

25.1.2 Maui study area $\ldots \ldots \ldots \ldots \ldots \ldots \ldots \ldots \ldots \ldots \ldots \ldots 44$

25.2 Animals .............................. 44

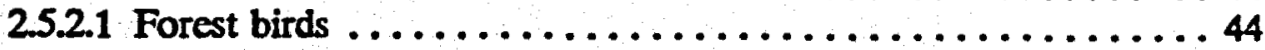

2.5 .2 .2 Waterbirds ......................... 48

25.3 Mammals ........................... 52

253 Protected Ecological Areas $\ldots \ldots \ldots \ldots \ldots \ldots \ldots \ldots \ldots \ldots \ldots \ldots \ldots$

2.5.3.1 Sensitive community types ................ 52

25.3.2 Protected ecological areas .................. 53

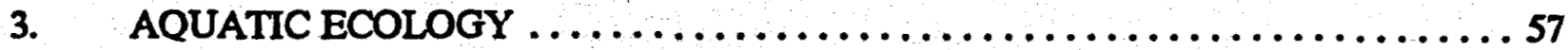

3.1 GEOTHERMAL RESOURCE ZONES $\ldots \ldots \ldots \ldots \ldots \ldots \ldots \ldots \ldots \ldots \ldots$

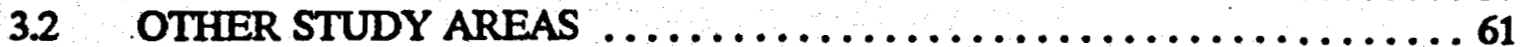

3.3 SOUTH MAUI AND OAHU STUDY AREAS $\ldots \ldots \ldots \ldots \ldots \ldots \ldots \ldots \ldots$

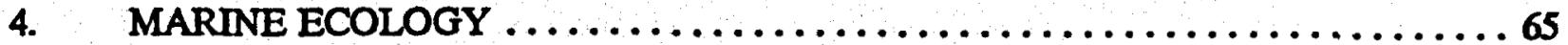

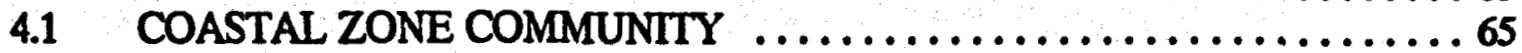

4.2 REEF COMMUNITY ............................... 67 
4.3 DEEP WATER COMMUNITY $\ldots \ldots \ldots \ldots \ldots \ldots \ldots \ldots \ldots \ldots \ldots$

4.4 THREATENED AND ENDANGERED MARINE SPECIES $\ldots \ldots \ldots \ldots \ldots 70$

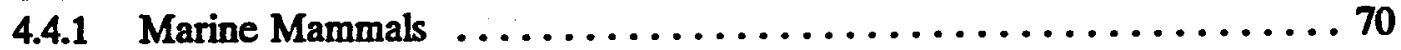

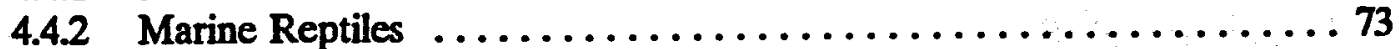

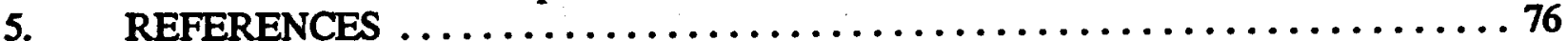

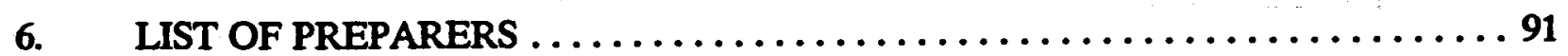




\section{IIST OF FIGURES}

Figure

Page

1 Vegetation types in the Kilauea geothermal resource zone $\ldots \ldots \ldots \ldots \ldots \ldots$

2 Vegetation types in the Kamaili and Kapoho geothermal resource subzones . . . . . . 10

3a Vegetation types in the vicinity of the study area, Hawaii $\ldots \ldots \ldots \ldots \ldots \ldots \ldots 21$

3b Vegetation types in the vicinity of the study area, Hawaii $\ldots \ldots \ldots \ldots \ldots \ldots \ldots$

3c Vegetation types in the vicinity of the study area, Hawaii $\ldots \ldots \ldots \ldots \ldots \ldots$

3d Vegetation types in the vicinity of the study area, Hawaii . . . . . . . . . . . . 24

3e Vegetation types in the vicinity of the study area, Hawaii $\ldots \ldots \ldots \ldots \ldots \ldots \ldots$

4 Coastal wetlands in the vicinity of the study area, Maui ................ 34

5 Coastal and inland wetlands in the vicinity of the study area, Oahu .......... 35

6 Coastal wetlands in the vicinity of the study area, Hawaii $\ldots \ldots \ldots \ldots \ldots \ldots$

7 Natural areas in the vicinity of the study area on Hawaii $\ldots \ldots \ldots \ldots \ldots \ldots \ldots$

8 Natural areas in the vicinity of the study area, Maui ................ 56

9 Perennial and ephemeral streams on the island of Hawaii $\ldots \ldots \ldots \ldots \ldots \ldots$

10 Location of anchialine pools near the Kilauea east rift subzone . . . . . . . . . . . . 59

11 Location of streams on the island of Maui with respect to the study area ........6 63

12 Map and topographic profile of Waimanalo Bay $\ldots \ldots \ldots \ldots \ldots \ldots \ldots \ldots \ldots$

13 Map of important foraging and basking areas for the Hawaiian green

sea turtle Chelonia mydas . . . . . . . . . . . . . . . . . . . . . 
[blank page] 


\section{LIST OF TABLES}

Table

1 Vegetation community types and acreage within the Kilauea, Kamaili, and Kapoho subzones

2 Plants common to the vegetation types found in the three Kilauea, Kamaili, and Kapoho geothermal resource subzones $\ldots \ldots \ldots \ldots \ldots \ldots \ldots \ldots$

3. Average and largest patch size of vegetation communities types within the Geothermal Resource Zone $\ldots \ldots \ldots \ldots \ldots \ldots \ldots \ldots \ldots \ldots$

4 Comparison of landscape patterns within the Kilauea and Kamaili geothermal resource subzones $\ldots \ldots \ldots \ldots \ldots \ldots \ldots \ldots \ldots \ldots \ldots \ldots \ldots \ldots \ldots$

5. Native and introduced birds recorded or likely to occur in the

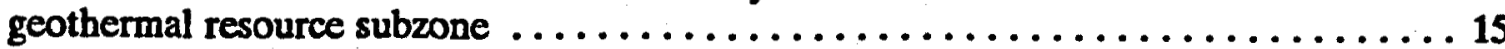

6 Invertebrates that have been identified in native vegetation communities in the vicinity of the Kilauea subzone $\ldots \ldots \ldots \ldots \ldots \ldots \ldots \ldots \ldots$

7 Native invertebrates occurring in lava tubes and crack habitats in the vicinity of the Geothermal Resource Zone

8 Code, map unit description, and area of vegetation community types delineated within the study area on the island of Hawaii .

9 Endemic forest birds, excluding federally listed endangered species, which may occur in the study area

10 Native invertebrates occurring in lava tubes and crack habitats along the study area in the vicinity of the Saddle Road

11 Threatened and endangered plant species within the study area on

Hawaii

12 Endangered and threatened plant taxa that might be found in the study area on Maui

13 Endangered or threatened animals in the study area on the islands

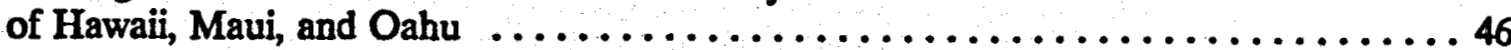

14 Species of marine mammals reported off Hawaii $\ldots \ldots \ldots \ldots \ldots \ldots \ldots \ldots$

15 Species endangered $(E)$ or threatened $(T)$ of marine reptiles reported off Hawaii 
[blank page] 


\section{ACRONYMS AND ABBREVIATIONS}

$\begin{array}{ll}\text { ASL } & \text { above sea level } \\ \text { COE } & \text { U.S. Army Corps of Engineers } \\ \text { DBED } & \text { Department of Business and Economic Development, State of Hawaii } \\ \text { DOE } & \text { U.S. Department of Energy } \\ \text { EIS } & \text { environmental impact statement } \\ \text { Fed. Regis. } & \text { Federal Register } \\ \text { ft } & \text { feet } \\ \text { FWS } & \text { U.S. Fish and Wildlife Service } \\ \text { GRZ } & \text { geothermal resource zone } \\ \text { ha } & \text { hectare } \\ \text { HGP } & \text { Hawaii Geothermal Project } \\ \text { HHP } & \text { Hawaii Heritage Program } \\ \text { KERZ } & \text { Kilauea east rift zone } \\ \text { km } & \text { kilometer } \\ \text { m } & \text { meter } \\ \text { NAR } & \text { natural area reserve } \\ \text { NMFS } & \text { National Marine Fisheries Service } \\ \text { TNCH } & \text { The Nature Conservancy of Hawaii } \\ \text { USAF } & \text { U.S. Air Force }\end{array}$


[blank page] 


\section{INTRODUCTION}

This report has been prepared to make available and archive the background scientific data and related information collected on ecological resources during the preparation of the environmental impact statement (EIS) for Phases 3 and 4 of the Hawaii Geothermal Project (HGP) as defined by the state of Hawaii in its April 1989 proposal to Congress. The U.S. Department of Energy (DOE) published a notice in the Federal Register on May 17, 1994 (Fed. Regis. 59, 25638) withdrawing its Notice of Intent (Fed. Regis. 57, 5433) of February 14, 1992, to prepare the HGP EIS. Since the state of Hawaii is no longer pursuing or planning to pursue the HGP, DOE considers the project to be terminated.

The background scientific data and related information presented in this report focus on several areas of Hawaii County, including the southeastern coast, a potential development corridor along the Saddle Road between Hilo and the North Kohala District on the northwestern coast, and on the southeastern coast of Maui. In this report, reference is made to these areas as study areas rather than as areas where proposed or alternative facilities of the HGP would be located. The resource areas addressed herein include terrestrial ecology, aquatic ecology, and marine ecology. The scientific background data and related information that were obtained from review of the (1) scientific literature, (2) government and private sector reports, (3) studies done under DOE interagency agreements with the U.S. Fish and Wildlife Service (FWS) and with the U.S. Army Corps of Engineers (COE), and (4) observations made during site visits are being made available for future research in these areas. This report describes the environmental resources present in the areas studied (i.e., the affected environment) and does not represent an assessment of environmental impacts.

\section{TERRESTRIAL ECOLOGY}

Hawaiian biota is unique because it has evolved over 5 million years in isolation (Stone and Stone 1989). Over 93\% of native Hawaiian plants are endemic (native to a region and not found anywhere else), which is the highest proportion of endemic plants found on any land area on earth. The isolation of the Hawaiian Islands precluded colonization by many genera; hence, speciation and adaptation by relatively few species have given rise to the unique composition and structure of the Hawaiian biota. The development of native vegetation is strongly conditioned by elevation and aspect (i.e., the direction of exposure) because of their effects on precipitation and temperature. Soil substrate is another factor affecting the development of the vegetation. Because of these factors the vegetation communities on the Hawaiian Islands exhibit a distinct zonal pattern (Ripperton and Hosaka 1942) that includes coastal lowland [ $<500 \mathrm{~m}$ (1640 ft)], montane [500-2000 m (1640-6560 ft)], subalpine [>2000-2800 m (6560-9184 ft)], and alpine [>2800 m (9184 ft)] elevational regions (Cuddihy and Stone 1990). Within each of these regions moisture regimes affect the development of forest and grassland communities (Cuddihy 1989). The 
geothermal resource zone (GRZ) and other study areas involve all of the biotic zones on the island of Hawaii except alpine. The areas within these biotic zones encompass a diverse landscape that includes both native, undisturbed ecosystems and highly disturbed, nonnative ecosystems. Because the native Hawaiian biota are unique (Mueller-Dombois, Bridges, and Carson 1981; Stone and Scott 1985), and the colonization and subsequent development of the islands have altered the natural landscape (Stone, Smith, and Tunison 1993), it is important to develop a historical context of the existing ecological resources.

Agricultural practices used by Native Hawaiians were a major cause of change in vegetation communities on the islands, principally in those areas receiving more than $50 \mathrm{~cm}$ (20 in.) of rainfall and lying below $460 \mathrm{~m}$ (1500 ft) elevation (Cuddihy and Stone 1990). In the Puna area, which encompasses the GRZ, traditional cultivation involved slash-and-burn techniques. The forest zone, which includes the Kilauea and Kamaili subzones, was used for wild plant products, canoe logs, and hunting and gathering. Above $760 \mathrm{~m}(2500 \mathrm{ft}$ ) elevation (which includes portions of the study area ), the original vegetation was not disturbed by the Native Hawaiians before European contact in ca. 1780 (Kirch 1982). Change caused by Native Hawaiians before $\mathbf{1 7 8 0}$ in the lowland forest habitats is considered to be the reason for extinction of some native animals (Olson and James 1982; Kirch 1982).

The most significant changes in Hawaiian biota have occurred since European contact in 1778 (Cuddihy and Stone 1990), and those changes were the result of grazing by introduced mammals, clearing of land for agriculture, harvesting forest products, and urbanization. These uses have been accompanied by the introduction of alien plants, which competed with the native flora, and animals, which consumed native flora and enhanced the invasion of alien species (Kimura and Nagata 1980; Wester 1993; Vitousek 1986). Approximately 10\% of the native Hawaiian flora is extinct (Cuddihy and Stone 1990), and 40 to $50 \%$ may be threatened with extinction (Wagner, Herbst, and Lee 1985). The most pristine habitats occur in upper-elevation rain forests with difficult terrain and in areas where feral animals do not live. In other areas (e.g., coastal, lowland, montane), native vegetation is considered rare (TNCH 1987).

\section{GEOTHERMAL RESOURCE ZONE}

The following sections present information on the vegetation, fauna, and sensitive species for the GRZ. This information is based on Jacobi (1990) for the Kilauea subzone and on Lamoureux et al. (1985) for the Kamaili and Kapoho subzones. Recent studies by Jacobi et al. (1994) provide an update of vegetation resources in the GRZ, but were not available for reference in preparing the present report.

\subsection{Vegetation}

The GRZ on the island of Hawaii occurs at elevations between 10 and $800 \mathrm{~m}$ (33 and $2625 \mathrm{ft}$ ) above sea level (ASL). Within this elevation zone the native vegetation types range from 
coastal communities to low-elevation rain forests. The native coastal communities are characteristically influenced by the ocean. Today, areas of native coastal vegetation are rare because of previous disturbance. Native coastal communities in the Puna region were dominated by hala (Pandanus tectorius) and ohia (Metrosideros polymorpha) forests with an understory of Polynesian introductions and alien plants (Atkinson 1970, Cuddihy and Stone 1990). Present vegetation in the coastal zone in the vicinity of the study area is dominated largely by alien plants. Similarly, areas upslope of the coastal zone [50-300 m (160-980 ft) elevation] were dominated by low-elevation rain forests prior to colonization. Today ohia-dominated rain forests exist primarily above $300 \mathrm{~m} 980 \mathrm{ft}$ ) although isolated tracts exist below that elevation. These low-elevation ohia rain forests are among the largest intact low-elevation rain forests in Hawaii (Atkinson 1970, Cuddihy and Stone 1990).

Ohia is the dominant native tree species in Hawaii because it has adapted to a wide variety of sites and has relatively few competitors. It exists on both wet and dry sites ranging in elevation from sea level to $2800 \mathrm{~m}$ (9200 ft). Ohia is a pioneer species, being one of the first plants to colonize new lava flows (Little and Skolman 1989); it is also the dominant species in climax forests, which can occur on lava flows ranging in age from 200 to 2000 years. The plants in ohia rain forests generally occur in distinct tree canopy, shrub, and herbaceous layers (MuellerDombois et al. 1981). Common tree and shrub species in the different vegetation layers in the forests characteristic of the GRZ include ohia as the dominant tree species, as well as koa (Acacia koa), tree fern (Cibotium spp.), kolea (Myrsine lessertiana), olapa (Cheirodenron trigynum), kawa'u (Ilex anomala), kopiko (Psychotria spp.), 'alani (Pelea spp.), pilo (Coprosma spp.), kanawao (Broussaisia anguta), 'ohlo (Vaccinium calycinum), and oha-wai (Clermontia spp.). Ground ferns including 'ama'u (Sadleria spp.), akolea (Athyrium microphyllum), ho'i'o (A. sanwicensis), and lau-kahi (Dropteris walichiana) may also predominate in the shrub layer. While the diversity of native species is great in the rain forest, exotic species also exist and often compete with the native vegetation. Alien plant species that may exist in the ohia rain forests include strawberry guava (Psidium cattleianum), malabar melastome (Melastoma candidum), banana polka (Passiflora mollissima), Clidemia (Clidemia hirta), thimbleberry (Rubus rosifolius), kahili ginger (Hedychium garnerianum), and Christmas berry (Schinus terebinthifolius) (MuellerDombois et al. 1981).

Ohia forests are characteristically even-aged. These forests tend to develop distinct structural and compositional properties that depend on the age of the forest and landform (Drake and Mueller-Dombois 1993). An important factor affecting the structural diversity of the rain forest is a phenomenon recognized as stand-level ohia dieback. Dieback is a process in which cohort mortality is synchronized and expressed over relatively large areas. The cause of ohia dieback is thought to be the interactions between cohort senescence and perturbations that induce stress (Mueller-Dombois 1986, 1990). There are seven different types of dieback, reflecting differing ecosystem responses and interactions of causative factors (Hodges et al. 1986). In forests dominated by native species, ohia regeneration following dieback produces another cohort, and the successional development of the stand continues (Hodges et al. 1986; Mueller-Dombois 1986). 
In forests with a dense-tree fern canopy, ohia regeneration may be impaired, but the species will prevail (Mueller-Dombois 1986). In other stands with alien species, particularly strawberry guava, dieback may allow the alien plants in the understory to become dominant (Hodges et al. 1986).

The landscape of the low-elevation rain forests on the island of Hawaii is dynamic, since it is comprised of lava flows ranging in age from contemporary to several hundred years old. Ohia is the dominant plant involved with colonizing the recent lava and in sustaining the forest canopy in mature forests. The resultant landscape is a mosaic of stands of different ages, exhibiting different compositional and structural properties. This mosaic includes bare or recently colonized lava, dieback areas, regenerating dieback areas, and developing and mature ohia forests. This mosaic is sustained through the regenerative capacity of ohia and the availability of seed source. Because these ohia forests are the predominant community on the landscape, many forest birds (Carpenter and MacMillen 1973) and insects (Howarth and Mull 1992) have developed specific associations with ohia-dominated communities. The maintenance of this ohia-dominated landscape is dependent on a complimentary range of cohorts. Replacement dieback or invasions of alien species and forest destruction may alter the natural landscape dynamics of these forests (Vitousek 1986; Huenneke and Vitousek 1990).

Wet ohia forests predominate throughout the Kilauea subzone and in the higher elevations of the Kamaili subzone. Below $300 \mathrm{~m}$ ( $980 \mathrm{ft}$ ), highly disturbed vegetation communities are dominant, although there are small areas of intact forest throughout the Kamaili and Kapoho subzones. These vegetation communities are discussed below within the context of vegetation types developed by Lamoureux et al. (1985). Many of these vegetation types are directly analogous to forest types recognized by the FWS (Jacobi 1990), but they were expanded to include areas outside of the original survey area, which was generally above $460 \mathrm{~m}$ (1500 ft) elevation. The following discussion of vegetation communities utilizes vegetation types and representative species. A complete list of plant species reported to occur in the GRZ can be found in Lamoureux et al. (1985).

Kilauea subzone. Land within the Kilauea subzone is characterized by a mosaic of forest types and lava. Unvegetated lava flows occupy approximately $14 \%$ of this subzone. The ohia forests within this subzone are dominated by endemic plant species (Jacobi 1989, 1990), although alien species are a component of some of the ohia forests. The distribution of vegetation types in the Kilauea subzone is shown in Fig. 1, and the area of each vegetation type is presented in Table 1.

The lava flows delineated on the vegetation map include barren flows, and flows which support low densities of pioneer vegetation. The Pu'u O'o flows are completely barren. Slightly older flows (predating 1983) are sparsely vegetated by ohia and swordfern (Nephrolepis multiflora); lichen (Stereocaulon) may also cover 30 to $40 \%$ of the rock surface (Lamoureux et al. 1985). Kipukas, which are islands or pockets of vegetation contained within a recent lava flow that are formed when lava does not completely cover the forest vegetation, are scattered throughout the recent lava flows and are an inclusion within this barren lava map unit designation. Kipukas, 


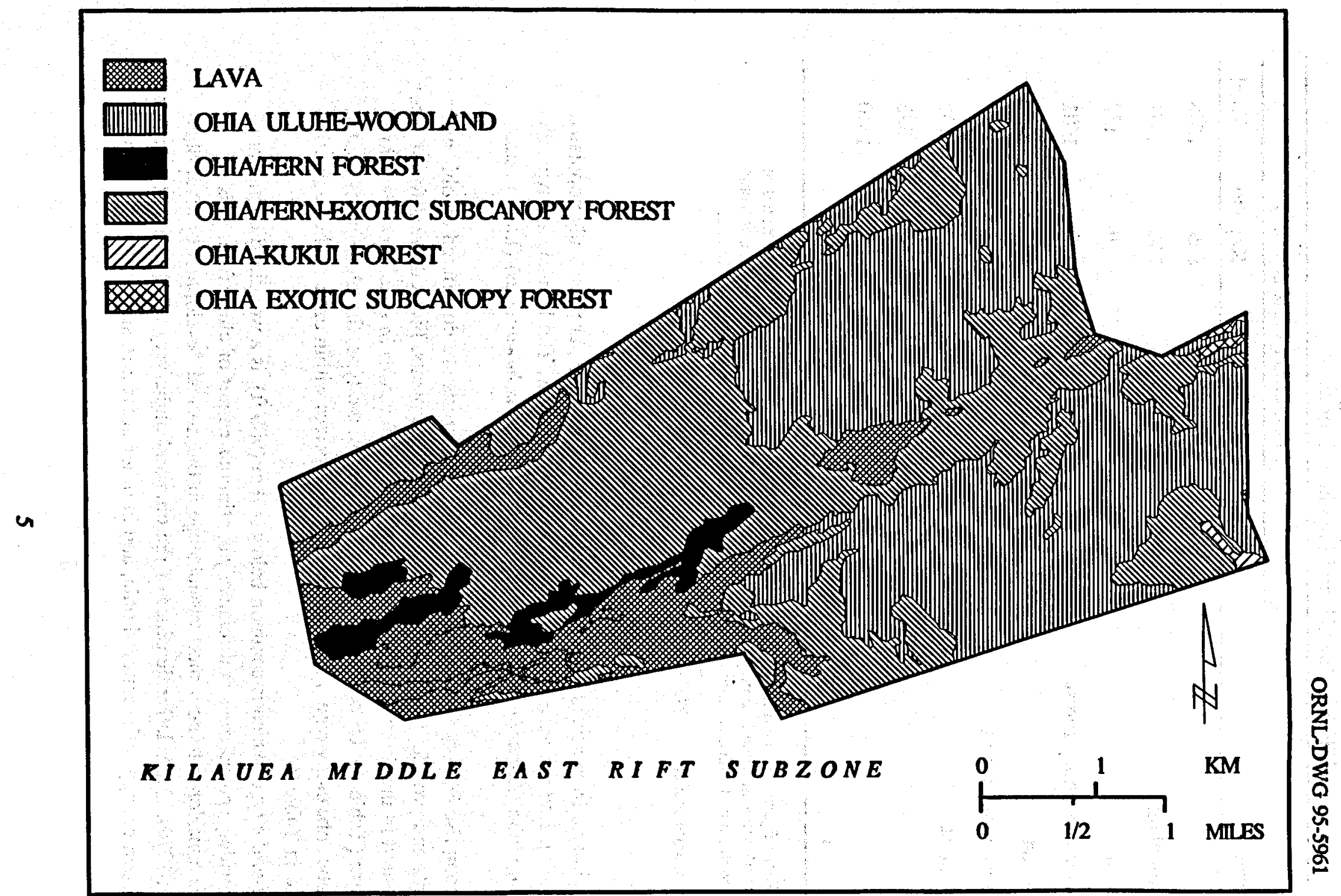

Fig. 1. Vegetation types in the Kilauea geothermal resource subzone. See text for description of vegetation types. Source: Lamoureux et al 1985. 
Table 1. Vegetation community types and acreage within the Kilauea, Kamaili, and Kapoho subzones

\begin{tabular}{lrrrr}
\hline & \multicolumn{4}{c}{ Geothermal subzones (ha) } \\
\cline { 2 - 5 } Vegetation type & Kilauea & Kamaili & Kapoho & Total \\
\hline Lava & 521 & 296 & 829 & 1646 \\
Ohia-uluhe woodland & 1445 & 350 & 256 & 2051 \\
Ohia/fern forest & 122 & 0 & 0 & 122 \\
Ohia/fern-exotic subcanopy forest & 1635 & 4 & 42 & 1681 \\
Ohia-kukui forest & 8 & 26 & 0 & 34 \\
Ohia-exotic subcanopy forest & 8 & 945 & 96 & 1049 \\
Mixed mesic forest & 0 & 0 & 231 & 231 \\
Scrub & 0 & 35 & 347 & 382 \\
Agriculture & 0 & 575 & 1265 & 1840 \\
& & & & \\
\hline
\end{tabular}

Note: These figures obtained from old and distorted base maps. There was a difference noted of about $140 \mathrm{~m}$ ( $460 \mathrm{ft}$ ) between some lava polygons observed in both this digitized coverage and the "Jacobi" coverage. It is undetermined which is more accurate. Therefore, these acreage are only approximate.

Source: Lamoureux et al. 1985.

which may range in size from several square meters to several hectares, are generally populated by plants which comprised the vegetation community before the flow. The kipukas are typically vegetated by ohia, uluhe (Dicranopteris spp.), and mamaki (Pipturus hawaiiensis) (Lamoureux et al. 1985).

Forests comprise $86 \%$ of the Kilauea subzone. These forests are dominated by ohia and other native plants and provide habitat for native fauna and rare plants. Five different forest types have been delineated in the three subzones to reflect major differences in species composition and stand structure (Table 2). These forests include the ohia-uluhe type, the ohia/fern type, and the ohia/fern-exotic subcanopy type. A list of the principal species within each of the vegetation types is presented in Table 2.

The ohia-uluhe type, which is common below $300 \mathrm{~m}$ (980 ft), is a woodland community characterized by widely spaced trees and relatively continuous carpet of uluhe fern. This vegetation type is considered to be a successional stage in the normal development of wet ohia forests (Atkinson 1970). The relative densities of the ohia and uluhe vary widely, with some areas being relatively open canopy with scattered ohia, and in other areas a relatively closed canopy of 
Table 2. Plants common to the vegetation types found in the three Kilavea, Kamaili, and Kapoho geothermal resource subzones

\begin{tabular}{|c|c|}
\hline Vegetation type & Common native species \\
\hline Lava & $\begin{array}{l}\text { Ohia (Metrosideros polymorpha), swordfern (Nephrolepis } \\
\text { multiflora) }\end{array}$ \\
\hline Ohia-uluhe woodland & $\begin{array}{l}\text { Ohia, uluhe (Dicranopteris spp.), kopiko (Psychotria } \\
\text { hawaiiensis), uki (Machaerina spp.) }\end{array}$ \\
\hline Ohia/fern forest & $\begin{array}{l}\text { Ohia, tree fen (Cibotium spp.), kawau (Mex anomala), } \\
\text { olapa (Cheirdendron trigymum), alani (Pelea clasaefolia), } \\
\text { kopiko, kanawao (Broussaisia arguta), pilo (Coprosma } \\
\text { spp.), Cytandra spp., Clermontia parviflora, akia } \\
\text { (Wikstroemia sandwicensis), and uluhe. }\end{array}$ \\
\hline $\begin{array}{l}\text { Ohia/fem - exotic subcanopy } \\
\text { forest }\end{array}$ & $\begin{array}{l}\text { Ohia, tree fern (Cibotium spp.), kawau (llex anomala), } \\
\text { olapa (Cheindendron trigmum), alani (Pelea clasaefolia), } \\
\text { kopiko, kanawao (Broussaisia arguta), pilo (Coprosma } \\
\text { spp.), Cytandra spp,, Clermontia parviflora, akia } \\
\text { (Wikstroemia sandwicensis), and uluhe. }\end{array}$ \\
\hline Ohia-kukui forest & $\begin{array}{l}\text { Ohia, kukui (Aleurites moluccana), tree fern, kawau, } \\
\text { olapa, alani, kopiko, kanawao, pilo, Cytandra spp., } \\
\text { Clermontia parviflora, akia, uluhe, awapuhi-kua-hiwi } \\
\text { (Zingibar serumbet), pi'ia (Disoscorea pentaphylla), } \\
\text { Hawailan bamboo (Schizostachyum glaucifolium), and ti } \\
\text { (Contyline terminalis), jackfruit (Artocarpus heterophyllus), }\end{array}$ \\
\hline
\end{tabular}

Ohia - exotic subcanopy forest Ohia, tree fern, kawau, olapa, alani, kopiko, kanawao, pilo, Cytandra spp., Clemontia parviflora, akia, uluhe.

Malabar melastome (Melastoma candidum), strawberry guava (Psidium cattleianum), bamboo orchid (Anundina bambusaefolia)

Common alien species

Malabar melastome, strawberry guava, bamboo orchid

Malabar melastome, strawberry guava, bamboo orchid, avocado (Persea americana), and Philodendron spp.

Malabar melastome, strawberry guava, bamboo orchid, basket grass, thimbleberry (Rubus rosaefolius), downy wood fern (Christella dentata), 'awapuhi-kua-hiwi, honohono (Commelina diffusa), Spathoglottis plicata, fireweed, ti, pi'ia, ginger (Hedychium spp.), and Hilo grass 
Table 2 (continued)

\begin{tabular}{|c|c|c|}
\hline Vegetation type & Common native species & Common alien species \\
\hline Mbxed mesic forest & $\begin{array}{l}\text { Ohia, uluhe, hala (Pandanus spp.), hau (Hibiscus } \\
\text { tiliaceus), }\end{array}$ & $\begin{array}{l}\text { Niu (coscos nucifer), kukui (Aleurites moluccana), kamani } \\
\text { (Calophyllum inophyllum), 'ulu (Artocarpus altilis), milo } \\
\text { (Thespesia populnea), Java plum (Syzygium cumini), mango } \\
\text { (Mangifer indica), avocado, rose apple (Syzygium jambos), } \\
\text { guava (Psidium guajava), strawberry guava, Christmas berry, } \\
\text { and monkeypod (Samanea saman). }\end{array}$ \\
\hline Scrub & $\begin{array}{l}\text { Ohia, uluhe, 'akia (Wikstroemia sandwicensis), lama, } \\
\text { Fimbristaylis dichotoma, 'uki (Machaerina angustifolia), } \\
\text { kuolohia (Rhynchospora layanum), Pycreus polystachyos, } \\
\text { and Scleria testacea. }\end{array}$ & $\begin{array}{l}\text { Guava (Psidium guajava, P. cattleianum), malabar melastome, } \\
\text { broomsedge (Andropogon virginicus), molasses grass (Melinis } \\
\text { minutiflora), California grass (Brachiaria mutica), Napier } \\
\text { grass (Pennisetum purpureum), bush beardgrass (Andropogon } \\
\text { glomeratus), and Hilo grass. }\end{array}$ \\
\hline Agriculture & & $\begin{array}{l}\text { Abandoned agricultural lands:Thema orientalis, Cecropia spp., } \\
\text { melochia (Melochia umbellata), comb hyptis (Hyptis } \\
\text { pectinata), butterfly bush (Buddleja asiatica), pluchea } \\
\text { (Pluchea odorata), sensitive plant (Mimosa pudica var. } \\
\text { unijuga), honohono (Commelina diffusa), kyllinga (Kyllinga } \\
\text { brevifolia) and molasses grass (Melinis minutiflora). } \\
\text { Pastures lands: pangola grass (Digitaria decumbens), narrow- } \\
\text { leaved carpet grass (Axonopus affinis), and Hilo grass } \\
\text { (Paspalum congugatum). }\end{array}$ \\
\hline
\end{tabular}

Sources: Atkinson 1970; Jacobi 1989, 1990; Lamoureux et al. 1985 
ohia. Because the dense fern cover inhibits the establishment of other plants, diversity of species in this forest type is not great. The malabar melastome and strawberry guava may occur as dense stands, particularly in areas of recent disturbance or along openings in the forest.

The ohialfern forest type is composed of native species and provides the best example of relatively undisturbed wet ohia rain forest. These forests are characterized by a closed ohia canopy ( $>60 \%$ ) and a dense subcanopy of tree fern (Cibotium spp.). Terrestrial and epiphytic ferns, including the rare Adenophorus periens, are common in this type. The ohialfern forest type occupies a relatively small area within the subzone, consisting of approximately 122 ha (301 acres). Areas of this type within the GRZ continue to be reduced by lava flows from ongoing eruptions at Pu'u O'o and associated vents (Atkinson 1970, Lamoureux et al. 1985).

The ohialfern-exotic subcanopy forest type occupies the largest area in the subzone, approximately 1635 ha (4040 acres) (Table 1). This type is similar to the ohia/fern forest except that the canopy tends to be more open, and alien shrubs and trees are found throughout the forest. Although tree ferns are common, they do not form the dense canopy that is characteristic of the ohialfern forests. Strawberry guava may exist as a dominant subcanopy species in areas that have been disturbed by pigs. The guava also occurs in dieback areas, where it has formed dense stands from advanced regeneration (Atkinson 1970, Lamoureux et al. 1985).

Kamaili and Kapoho subzones. Vegetation in the Kamaili and Kapoho subzones reflects the long-established and ongoing use of the area for agriculture and dwelling. As a result the vegetation in these subzones is dominated by alien species. Ohia forests within these subzones comprise approximately $59 \%$ of the land area (Table 1).

The agriculture vegetation type, shown in Fig. 2, includes cultivated lands, fallow fields, abandoned fields, pastures, and associated roads. This vegetation type comprises about 1840 ha (4546 acres), which is $35 \%$ of the area in these two subzones. Sugarcane (Saccharum officinarum) and papaya (Circa papaya) are the primary agricultural crops in the Puna region. Abandoned agricultural lands and pasture lands contain a variety of alien species (Table 2). Scattered ohia trees also exist in the pastured lands.

Ohia forests in these subzones include the ohia-uluhe and the ohia/fern-exotic subcanopy types, described above in the Kilauea section. Two other ohia types are also present in these two subzones. The ohia-kukui forest is similar to the ohialfern-exotic subcanopy forest except that the kukui (Aleurites moluccana), introduced from Polynesia, is a co-dominant tree. Some parts of this forest type have been cultivated by the Native Hawaiians in the past. Common species in the ohia-kukui forest are listed in Table 2.

Approximately 1048 ha (2590 acres) of the Kamaili and Kapoho subzones are vegetated by wet ohia forests which have a subcanopy and shrub layer dominated by alien species (the wet ohia-exotic subcanopy type). This forest type is similar to the ohialfern-exotic subcanopy forest except for the predominance of strawberry guava in the subcanopy and malabar melastome in the shrub layer. Other alien plants in the shrub and herbaceous layer are also common (Table 2). 


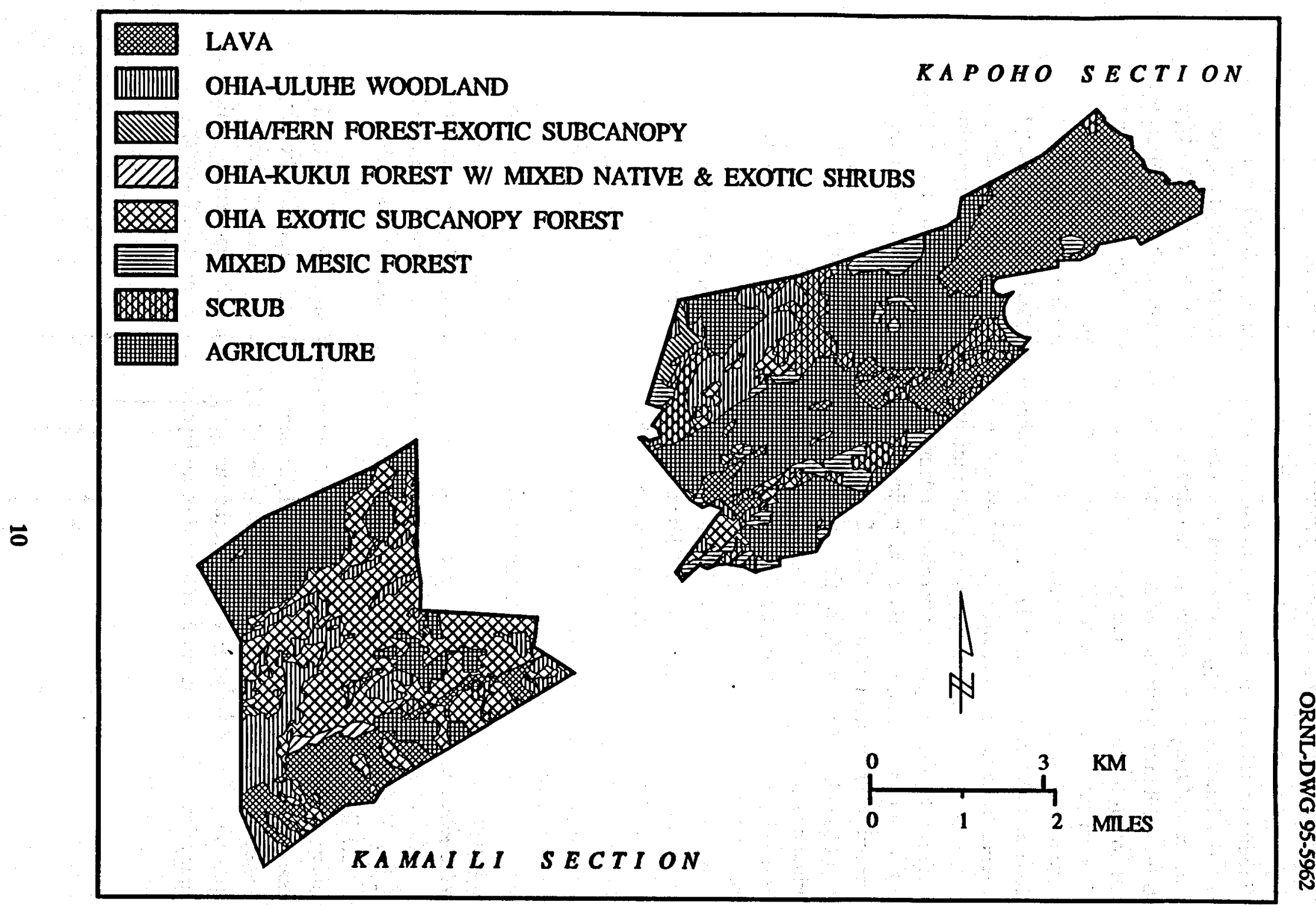

Fig. 2. Vegetation types in the Kamaili and Kapoho geothermal resource subzones (after Lamoureux et al. 1985). See text for description of vegetation types. 
Some native species do exist in the understory but they are relatively uncommon. Areas in this vegetation type are thought to have been disturbed extensively in the past (Lamoureux et al. 1985).

The mixed mesic forest is a mosaic of plant associations occurring at low elevations within the Kapoho subzone. This forest community is similar to the wet ohia forest types. It contains many of the same species as the wet ohia forests in addition to hala (Pandanus spp.), and hau (Hibiscus tiliaceus). This forest type reflects the effect of Polynesians introductions and more recently introduced alien species (Table 2). The mixed lowland forests in the Kapoho subzone consist of a mixture of native trees [ohia and lama (Diospyros ferrea spp. sandwicensis)] and the aliens mentioned above. The density of the shrub and ground cover varies depending on the density of the forest canopy. In highly disturbed areas strawberry guava and malabar melastome may form dense canopies.

The scrub vegetation type is found on approximately 382 ha (945 acres) of the GRZ, in areas that have been frequently disturbed or cleared in the past. The structure of the community varies from open grassy areas with scattered shrubs and trees to dense, closed scrub. The vegetation is dominated by alien grasses and shrubs (Table 2). Strawberry guava may form very dense stands on highly disturbed lands. Because of past disturbances, this vegetation type contains few native species (Table 2).

Landscape characteristics. Vegetation communities in the GRZs comprise a mosaic that reflects natural succession and the effects of past disturbances. The arrangement and composition of these vegetation communities affect landscape functions (e.g., forest bird habitat, biotic diversity). Accordingly, analyses of the pattern and arrangement of these communities on the landscape may provide a useful basis for assessing ecosystem change associated with perturbations (Franklin and Forman 1987).

Metries characterizing landscape pattern (O'Neill et al. 1988) were calculated to quantify the existing resource conditions and to characterize the effect of recent lava flows on landscape pattern. Three landscape metrics were used:

Dominance - a measure of the extent to which a few vegetation types dominate the landscape. Large values reflect landscapes dominated by a few vegetation types. Small values reflect many vegetation types.

Contagion - a measure of the extent to which vegetation types are aggregated or clumped. Large values reflect the clumping of large, contiguous patches. Small values reflect a landscape that is dissected into small patches.

Spatial complexity - an index of shapes. If a landscape is composed of simple geometric shapes, the fractal dimension will approach 1.0. If the landscape contains many patches with complex shapes, the fractal dimension will be large.

This information can be used as a reference point for assessing change associated with resource zone development or change associated with natural landscape processes (e.g., lava flow, ohia 
dieback). Roads are the major factor affecting the patch size (i.e., the size of a delineated vegetation map unit) of the community types (Table 3). The effect of roads was most pronounced on the ohia/uluhe type where average patch size was reduced by one-half. The spatial arrangement of vegetation communities is controlled by lava flows. Comparison of the landscape

Table 3. Average and largest patch size of vegetation communities types within the Geothermal Resource Zone

\begin{tabular}{lcccc}
\hline & \multicolumn{2}{c}{ Average patch size (ha) } & \multicolumn{2}{c}{ Largest patch size (ha) } \\
\cline { 2 - 5 } Vegetation type & $\begin{array}{c}\text { Vegetation } \\
\text { only }\end{array}$ & $\begin{array}{c}\text { Existing } \\
\text { conditions }^{b}\end{array}$ & $\begin{array}{c}\text { Vegetation } \\
\text { only }^{\circ}\end{array}$ & $\begin{array}{c}\text { Existing } \\
\text { conditions }^{b}\end{array}$ \\
\hline Lava & 82.3 & 28.2 & 657.4 & 436.9 \\
Ohia/uluhe & 49.3 & 25.6 & 973.6 & 964.9 \\
Ohia/fern & 40.6 & 40.6 & 63.0 & 63.0 \\
Ohia/fern exotic subcanopy & 56.0 & 48.0 & 1120.1 & 1079.5 \\
Ohia-kukui & 17.0 & 11.3 & 25.7 & 25.4 \\
Ohia-exotic subcanopy & 33.8 & 11.0 & 703.3 & 402.8 \\
Mixed mesic & 8.2 & 4.5 & 52.2 & 52.2 \\
Scrub & 13.7 & 4.9 & 110.9 & 103.3 \\
Agriculture & 73.6 & 5.0 & 1160.5 & 89.1 \\
\hline
\end{tabular}

Excludes roads.

Current condition including roads.

Source of data: Lamoureux et al. 1985.

metrics of a vegetation-only scenario without recent lava flows with the existing condition confirms that indices of shape, aggregation, and dominance are unchanged (Table 4). Analyses of those same metrics with existing roads show that roads reduce the degree of aggregation (i.e., contagion is reduced) and that shape complexity is also simplified (i.e., shape complexity index is reduced). Roads effectively bisect vegetation communities and hence would effectively disaggregate them. Similarly, since roads have a smooth, linear shape on the landscape, their presence serves to decrease the irregular pattern that is inherent in a lava-dominated landscape. Roads also serve to increase the amount of open edge within forested areas (Table 4). 
Table 4. Comparison of landscape patterns within the Kilauea and Kamaili geothermal resource subzones

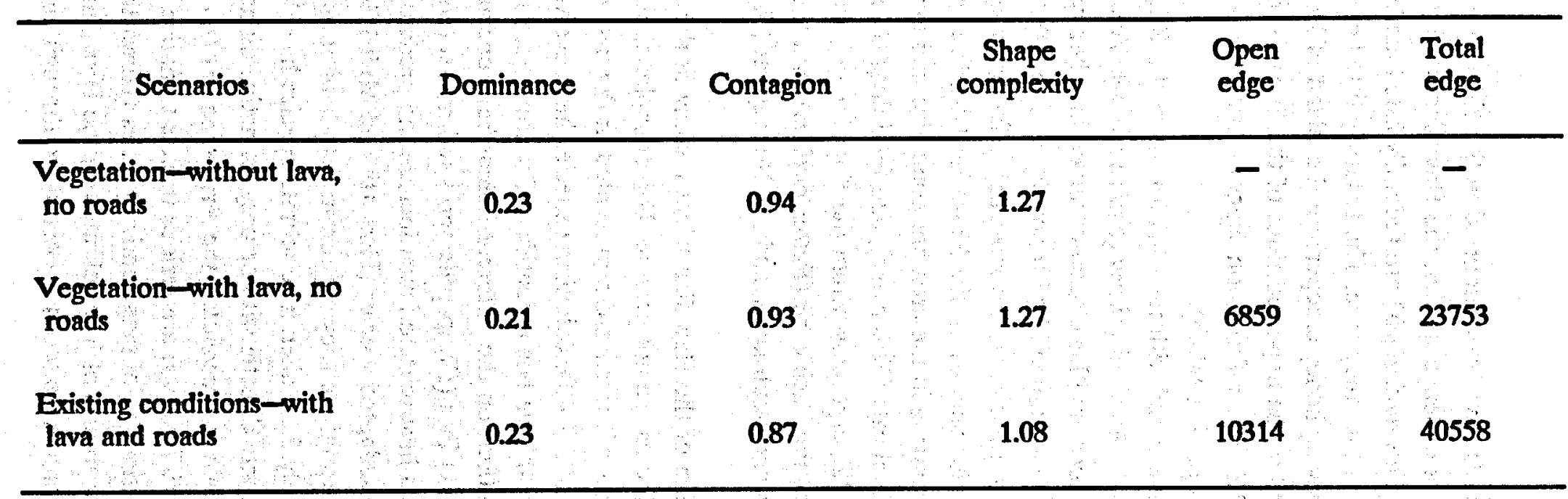

Note. Analyses were conducted according to O'Neil et al. (1988). see text for explanation of metrics. Existing vegetation coverage was estimated using data from Lamoureux et al. 1985. 


\subsection{Fauna}

Avifauna. Twenty-three species of birds have been reported in the Kilauea, Kamaili, and Kapoho subzones (Table 5). Among the eight endemic species, the Hawaiian hawk (Buteo solitarius) and the Newell's shearwater (Puffinus auricularis) are federally listed, endangered species that have been recently sighted within the study area. The federally listed endangered 'O'u (Psittorostra psittacea), the rarest of the surviving honey creepers on the island of Hawaii, has been observed in Volcano National Park and in the upper portions of the Puna Forest Reserve, areas which are adjacent to the Kilauea GRZ. This information suggests that the ' $O$ 'u may also occur within the Kilauea subzone (Reynolds et al. 1994a,b).

The endemic species are generally associated with the ohia forests in the Kilauea subzone; although 'Elepaio (Chasiempis sandwichensis), 'Amakihi (Hemingbathus virens), 'Apapane (Himatione sanguinea), and 'T'iwi (Vestiaria coccinea) have been observed in other types of forested areas of Kamaili and Kapoho subzones (unpublished report by S. Conant).

Mammals. The Hawaiian hoary bat (Lasiurus cinereus semotus), a federally listed endangered species, which is the only endemic mammal on the Hawaiian Islands, is present in the GRZ (see Sect. 2.5.2.3). Other mammals occurring in the area are nonnative and include feral pigs (Sus scrofa), feral cattle (Bos taurus), feral cats (Felis catus), and feral dogs (Canis familiaris). Four species of rodents occur within the GRZ, especially within the Kapoho and Kamaili subzones. The house mouse (Mus musculus), the Pacific rat (Rattus exulans), and the roof rat ( $R$. rattus) occur commonly in agricultural areas and scrub lands, and the Norway rat ( $R$. norvegicus) has been reported near habitations.

Invertebrates. Because of the isolation of the Hawaiian Islands, many of the invertebrate groups that occur on North American continents are not present. For example, about half of the known orders and $15 \%$ of the known families of insects are represented in the native fauna (Howarth and Mull 1992). It is estimated that $350-400$ colonizing species have evolved into more than 10,000 native species, of which only 5500 have been identified. Different habitats provided by vegetation, soil, water, and climatic conditions on the different islands have encouraged speciation, especially with respect to Hawaiian flies (Drospophia spp.) and moths (Hyposmocoma spp.). Other unique features of the Hawaiian invertebrate fauna include the predatory caterpillars (Eupithecia spp.), flightless insects, and cave-adapted species (Howarth and Mull 1992). Because the native fauna are dependent on native vegetation, they are sensitive to habitat alteration and competition from alien species. Approximately 3200 alien invertebrate species have been identified in Hawaii; these species may compete directly with or prey on native fauna, or they may transmit disease. The big-headed ant (Pheidole megacephala), the Argentine ant (Iridomyremex humilis), and the long-legged ant (Anoplolepis longipes) are serious threats to native invertebrates and have been implicated as the cause of extinction of many native species (Howarth and Mull 1992). Because there are relatively few studies of invertebrates on the Hawaiian Islands relevant to the GRZ, biotic surveys of this area have recently been done through an interagency 
Table 5. Native and introduced birds recorded or likely to occur in the geothermal resource subzones

\begin{tabular}{|c|c|c|c|c|}
\hline$\cdots$ & 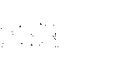 & & lal resourc & one $e^{b}$ \\
\hline Species & Status" & Kilauea & Kamaili & Kapoho \\
\hline $\begin{array}{l}\text { Buteo solitarius } \\
\text { Hawaiian Hawk, T'o }\end{array}$ & $\mathrm{N}, \mathrm{E}$ & + & + & + \\
\hline $\begin{array}{l}\text { Puffinus auricularis } \\
\text { Newell's Shearwater }\end{array}$ & $\mathrm{N}, \mathrm{E}$ & + & + & + \\
\hline $\begin{array}{l}\text { Psittorostra spittacea } \\
\text { 'o'u }\end{array}$ & $\mathrm{N}, \mathrm{E}$ & + & - & - \\
\hline $\begin{array}{c}\text { Myadestes obscurus } \\
\text { Oma'o }\end{array}$ & $\mathbf{N}$ & + & - & - \\
\hline $\begin{array}{l}\text { Chasiemphis sandwichensis } \\
\text { 'Elepaio }\end{array}$ & $\mathbf{N}$ & + & + & - \\
\hline $\begin{array}{l}\text { Hemignathus virens } \\
\text { 'Amakihi }\end{array}$ & $\mathbf{N}$ & + & + & - \\
\hline $\begin{array}{c}\text { Vestiaria coccinea } \\
\text { 'Tiwi }\end{array}$ & $\mathbf{N}$ & + & + & - \\
\hline $\begin{array}{c}\text { Himatione sanguinea } \\
\text { 'Apapane }\end{array}$ & $\mathbf{N}$ & + & + & - \\
\hline $\begin{array}{l}\text { Pluvialis dominica } \\
\text { Lesser Golden Plover, Kolea }\end{array}$ & $\mathbf{M}$ & - & + & + \\
\hline $\begin{array}{l}\text { Callipepla califomica } \\
\text { California Quail }\end{array}$ & $\mathbf{A}$ & - & + & - \\
\hline $\begin{array}{l}\text { Phasianus colchicus } \\
\text { Ring-necked Pheasant }\end{array}$ & $\mathbf{A}$ & - & + & + \\
\hline $\begin{array}{l}\text { Lophura leucomelana } \\
\text { Kalij Pheasant }\end{array}$ & A & - & + & - \\
\hline $\begin{array}{l}\text { Tyto alba } \\
\text { Barn Owl }\end{array}$ & A & - & + & + \\
\hline $\begin{array}{r}\text { Streptopelia chinensis } \\
\text { Spotted Dove }\end{array}$ & A & + & + & + \\
\hline $\begin{array}{l}\text { Geopelia striata } \\
\text { Barred Dove }\end{array}$ & A & - & + & + \\
\hline $\begin{array}{l}\text { Columba livia } \\
\text { Rock Dove }\end{array}$ & A & - & + & + \\
\hline
\end{tabular}


Table 5 (continued)

\begin{tabular}{|c|c|c|c|c|}
\hline \multirow{2}{*}{ Species } & \multirow[b]{2}{*}{ Status ${ }^{a}$} & \multicolumn{3}{|c|}{ Geothermal resource subzone ${ }^{b}$} \\
\hline & & Kilauea & Kamaili & Kapoho \\
\hline $\begin{array}{l}\text { Garrulax canorus } \\
\text { Melodious Laughing-thrush }\end{array}$ & $\mathbf{A}$ & + & + & + \\
\hline $\begin{array}{l}\text { Zosterops japonicus } \\
\text { Japanese White-eye }\end{array}$ & $\mathbf{A}$ & + & + & + \\
\hline $\begin{array}{l}\text { Acridotheres tristis } \\
\text { Common Myna }\end{array}$ & A & - & + & + \\
\hline $\begin{array}{l}\text { Lonchura punctulata } \\
\text { Spotted Munia }\end{array}$ & A & + & + & + \\
\hline $\begin{array}{l}\text { Passer domesticus } \\
\text { House Sparrow }\end{array}$ & $\mathbf{A}$ & - & + & + \\
\hline $\begin{array}{l}\text { Cardinalis cardinalis } \\
\text { Northern Cardinal }\end{array}$ & $\mathbf{A}$ & + & + & + \\
\hline $\begin{array}{c}\text { Carpodacus mexicanus } \\
\text { House Finch }\end{array}$ & $\mathbf{A}$ & + & + & + \\
\hline
\end{tabular}

eStatus: $\mathrm{N}=$ rative, endemic to the island of Hawaii; $\mathrm{M}=$ regular migrant visitor; $\mathrm{A}=$ alien introduced species; $\mathrm{E}=$ cndangered

'Species recorded present $(+)$ or absent $(-)$

Source: Lamourex et al. 1985. 
agreement between DOE and the FWS to identify unique habitats or organisms; a report on this study will be submitted to DOE and made available in public reading rooms in late 1994.

Ohia forests throughout the GRZ support many native invertebrates (Gagne and Christensen 1985). The list of invertebrates reported in forests adjacent to the Kilauea subzone (see Table 6) is based on very limited survey data, and a much more diverse array of organisms is likely to be present (see Sect. 2.2.2).

Lava tubes support unique invertebrate communities (Berger et al. 1981; Howarth 1981; Howarth and Mull 1992), including several endemic species of spiders, flightless crickets,

Table 6 Invertebrates that have been identified in native vegetation communities in the vicinity of the Kilauea subzone

\begin{tabular}{ll}
\hline Scientific name & Common name \\
\hline Theridion grallator & Hawaiian Happy-face spider \\
Theridiid sp. & Cobweb spiders \\
Salticid sp. & Jumping spiders \\
Tetragnathid sp. & Four-fanged orb spiders \\
Thomisid sp. & Crab spiders \\
Lispocephala sp. & Predatory muscid flies \\
Dolichopodid sp. & NA \\
Drosophilid sp. & Hawailan pomace flies \\
Tipulidae sp. & Hawailan crane flies \\
Microlepidopteran sp. & Small-bodied moths \\
Macrolepidopteran sp. & Large-bodied moths \\
Eupithecia sp. & Hawaiian predatory caterpillars \\
Collembolan sp. & Springtails \\
Amphipod sp. & NA \\
Succinid sp. & Hawaiian amber snails \\
Tomatellinid sp. & Minute land snails \\
\hline
\end{tabular}

Source: Based on unpublished data by MCM Planning provided to the DBED in 1989. 
springtails, and centipedes. Although there has not been a comprehensive survey of the cavedwelling species within the study area, the species reported by McEldowney and Stone (1991) demonstrate the importance of lava tube habitats (Table 7). These invertebrate populations in Puna exhibit a high degree of localized variation among taxa, which is an important biological phenomena (McEldowney and Stone 1991).

Nonnative invertebrates within the GRZ include ants, slugs, spiders, centipedes, and snails. These nonnative species are more common in the disturbed portions of the Kamaili and Kapoho subzones (Howarth and Mull 1992).

\section{OTHER STUDY AREAS ON HAWAII}

The following discussion of the ecological resources along a previously proposed transmission corridor is based on published information that has been developed for geothermal development initiatives (unpublished data by DHM, Inc., provided to the Hawaii Electric Light Company), water resource development (Okahara and Associates 1992), and the Hawaiian forest bird survey (Jacobi 1990). Because each of these assessments has used different vegetation community information, we have chosen to use the vegetative classification system developed by the FWS' (FWS 1985; Jacobi 1990) as a basis for discussion. This system has been developed for most forests on Hawaii, provides information at different spatial scales, and can be related to other existing data. The data reported below are based on surveys that are comparable to the scale reported in the GRZ (i.e., level-2 surveys) (Jacobi 1990).

\section{Vegetation}

The study area on the island of Hawaii traverses all of the vegetation/climatic zones present on the island except the alpine area. A diverse range in vegetation community types exists within each of these zones, reflecting the interactions of climate, substrate, and past disturbance. (See Mueller-Dombois et al. 1981 for a discussion of community development and organization along climatic and edaphic gradients in Hawaii). The study area starts at the GRZ, proceeds west through Pahoa and Glenwood, northwest to the Saddle Road, and then west along roadways (Saddle Road, Mamalahoa Highway, Kawaihae Road, and Akoni Pule Highway) to the Mahukona Harbor. The area includes low-, mid- and upper-elevation rain forests, mesic and dry forest and scrub lands, and ranch lands. Much of this area north of Pahoa through the Humuula Saddle is relatively undisturbed.

Vegetation communities within the study area from the GRZ to the Puna substation are characterized by ohia-uluhe and ohialfern-exotic subcanopy forests (unpublished data by Takeuchi and Imada provided to DHM, Inc.). Alien species are reported to be present in these forests, and Melastoma candidum is common. From Pahoa to the Puna substation, the study area follows Highway 130 and has a landscape highly dissected by urbanization, agriculture, and other human activities. Accordingly, native vegetation communities are rare in this area. Ohia forests along 
Table 7. Native invertebrates occurring in lava tubes and crack habitats in the vicinity of the Geothermal Resource Zone

\begin{tabular}{ll}
\hline Scientific name & Common name \\
\hline Anisolabis sp. (Labiduridae) & Cave earwig \\
Astigmata & Mite \\
Caconemobius varius (Gryllidae) & Cave cricket \\
Caconemobius sp. A (Gnyllidae) & Cave cricket \\
Caconemobius sp. B (Gnyllidae) & Cave cricket \\
Cryptostigmata & Mite \\
Erigone stygus (Linyphiidae) & Cave spider \\
Folsomia candida (Collembola) & Springtail \\
Forcipomyia sp. (Ceratopogonidae) & Fly \\
Hawinella lava & Springtail \\
Isopoda sp. & Cave isopod \\
Limonia cf. jacobus (Tpulidae) & Fly \\
Lithobius sp. (Lithobiidae) & Cave centipede \\
Lycosa howarthi (Lycosidae) & Cave hunting spider \\
Mesostigmata & Mite \\
Nicoletia meinerti (Lepismatiedae) & Silvertish \\
Olianus sp. (Sixidae) & Cave plant-hopper \\
Oonops? sp. (OOnopidae) & Cave spider \\
Protanura hawaïansis & Springtail \\
Schrankia sp. (Noctuidae) & Cave millipede \\
Sinella caeca & Springtail \\
Sinella vosia & Springtail \\
Speovelia aaa (Mesoveliidae) & Cave water strider \\
\hline
\end{tabular}

Note: "?" indicates uncertain classification.

Source: McEldowney and Stone 1991. 
Highway 130 contain an understory that is dominated by Melastoma candidum, Andropogon virginicus, Polygonum capitatum, Castilleja arvensis, Eragrostis unioloides, and Arundina bambusifolia. Abandoned agricultural fields and vegetation communities dominated by alien species (e.g., Psidium cattleianum, P. guajava, Mangifera indiiea, Pluchea symphytifolia, Albizzia spp., and Cecropia obtusifolia) are also common. Exceptions to these highly disturbed vegetation types within this section of the study area include the kipuka near the Pahoa Dump and the ohia forest along Highway 130 south of Pahoa (unpublished data by Takeuchi and Imada provided to DHM, Inc.).

The vegetation communities between the Pahoa substation and Waiki'i Ranch are shown in Fig. 3, and acreages of the community types are shown in Table 8. Not all lands within the study area have been mapped. In the Pahoa to Glenwood area (Fig. 3a), the vegetation communities are characteristic of low-elevation ohia-uluhe forests (no. 78) and ohia-tree fern forests (nos. 77, 79). These communities are similar to those described in Sect. 2.1.1, being dominated by native forest species but having alien species in the understory and subcanopy. This section of the study area traverses relatively large, unfragmented portions of low-elevation rain forest.

The study area from Glenwood to the Saddle Road traverses a large, intact, and undisturbed mid-elevation rain forest. The forest community is dominated by a ohialfern forest (nos. 77, 79; Fig. 3b). These forests are similar to other ohia/fern forests except that they do not contain alien species (for description see Sect. 2.1.1). Accordingly, these forests are part of what is now a relatively small area of undisturbed forests (Jacobi 1990) that provide important habitat for native forest birds (Scott et al. 1986) and insects (Howarth and Mull 1992). Above $1380 \mathrm{~m}$ $(4500 \mathrm{ft}$ ) the ohialfern forests intergrade with mesic ohia forests (nos. 55, 57; Fig. 3c). This is a transition zone between wet and dry precipitation zones (Jacobi 1990). These mesic ohia forests are characterized by an overstory of ohia, with native shrubs and tree fern in the understory (Jacobi 1990). Subcanopy trees may include Myrsine lessertiana, Ilex anomala, Phychotria spp., Pelea spp., Coprosma spp., Gouldia spp., Perrottetia sandwicensis, M. sandwicensis, Pisonia spp., and Osmanthus sandwicensis. Dominant native shrubs may include Broussaisia, Rubus hawaiiensis, Vaccinium calycinum, and occasionally Cibotium and Sadleria. Small areas of the mesic koa-ohia forests (nos. 52, 54, 44; Fig. 3c) also occur along this section of the study area. This latter type is similar to the mesic ohia forests except that koa is co-dominant. The koa-ohia forests may represent later successional stages of the mesic ohia forest communities (Jacobi 1990), and they represent natural communities without alien species.

Between the intersection with the Saddle Road and the Waiki'i Ranch substation, the vegetation grades from mesic shrub communities, at approximately $1500 \mathrm{~m}$ (5100 ft) to dry tree and shrub communities at $2000 \mathrm{~m}$ (6500 ft) (Fig. 3c,d). This change in vegetation reflects the reduction in precipitation as the study area extends leeward and higher in elevation. Mesic native shrub communities (no. 50; Fig. 3d) occur on recent lava flows between $1500 \mathrm{~m}(5000 \mathrm{ft}$ ) and $2000 \mathrm{~m}$ (6500 ft). The mesic community types reflect the xeric nature of the lava substrate. This community forms an early successional stage of ohia rain forests; dominant species include ohia, 
ORNL-DWG 95-5963

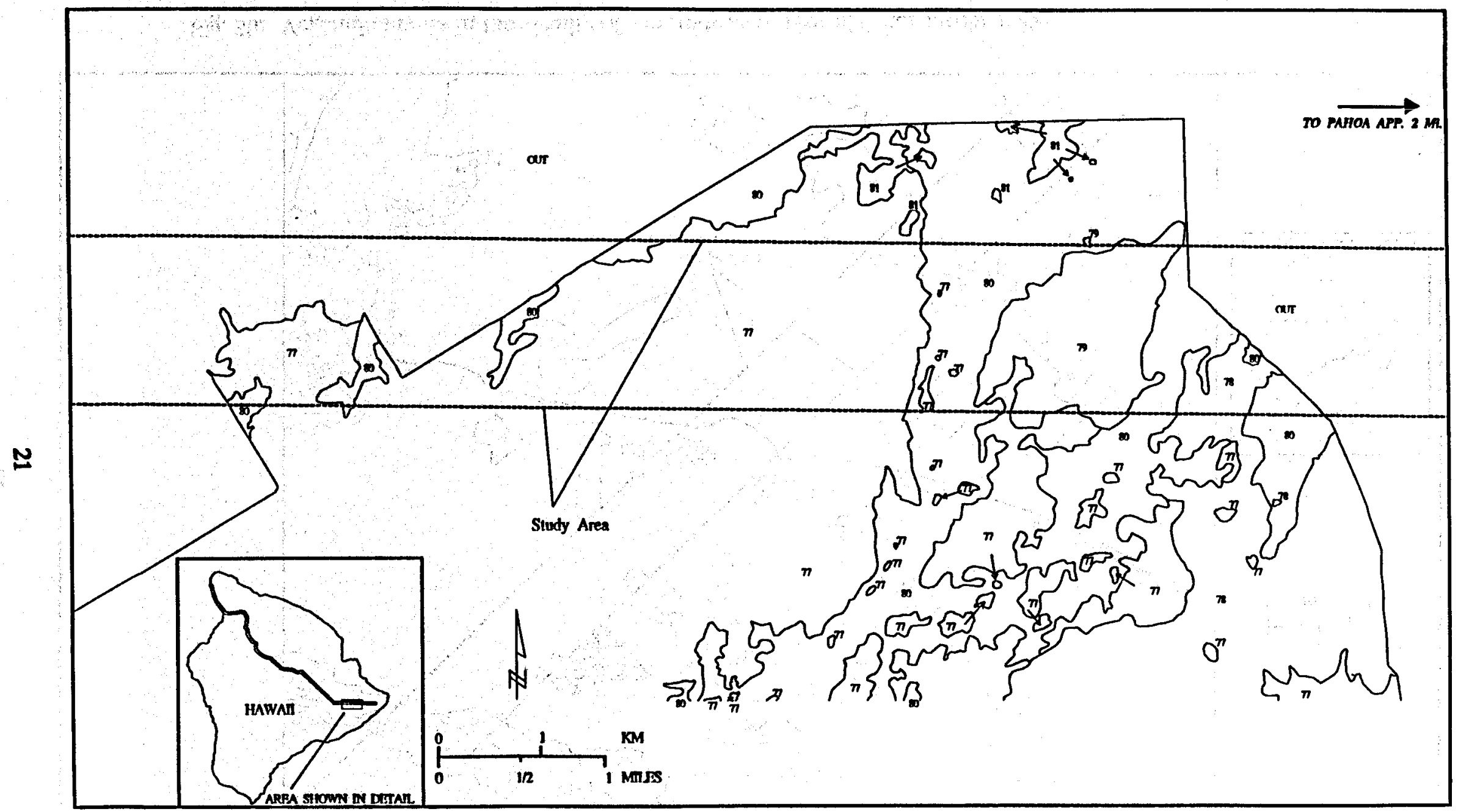

Fig. 3a. Vegetation types in the vicinity of the study area, Hawaii (after Jacobi 1989). 
ORNL-DWG 95-5964

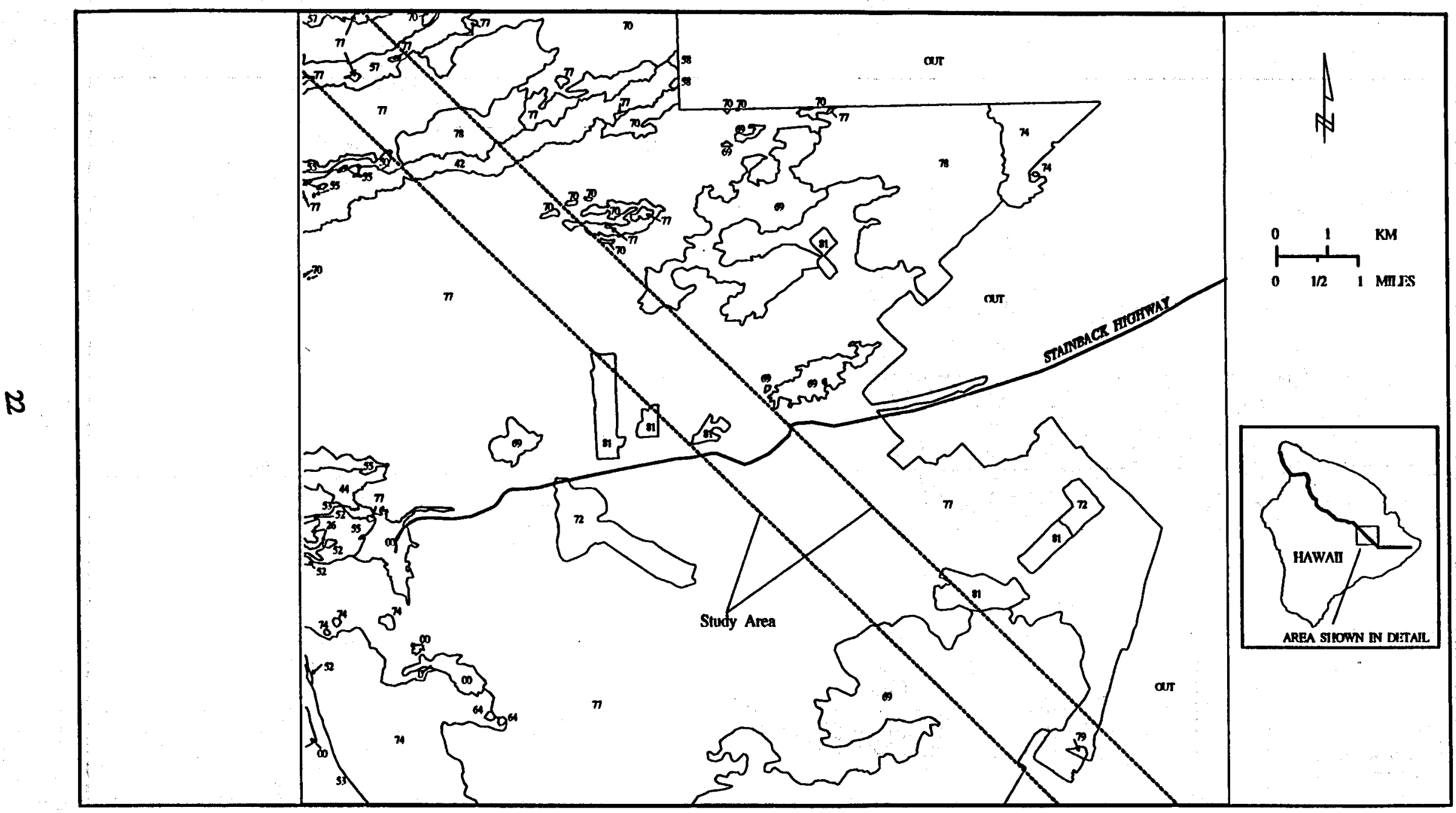

Fig. 3b. Vegetation types in the vicinity of the study area, Hawaii (after Jacobi 1989). 
ORNL-DWG 95-5965

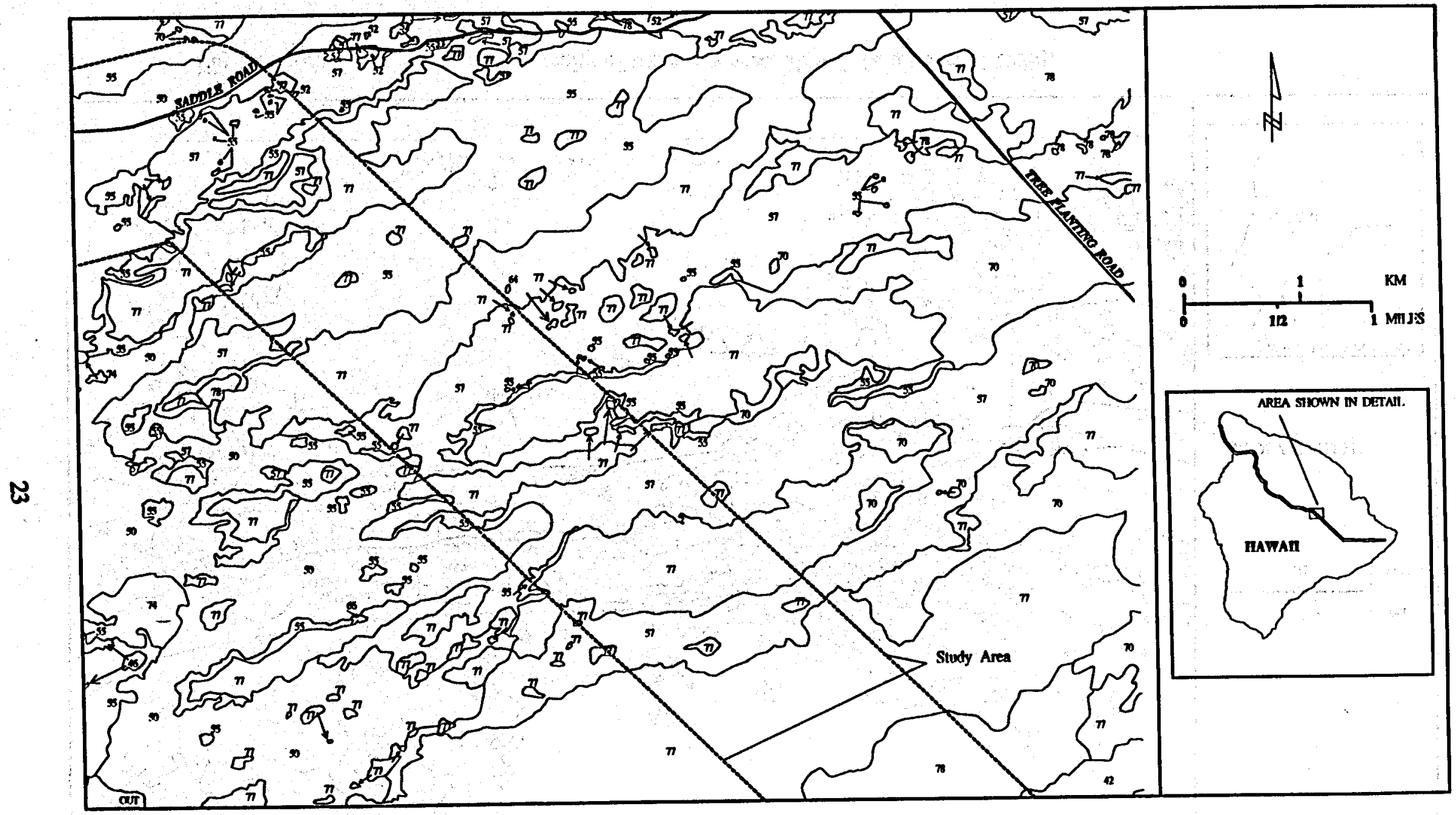

Fig. 3c. Vegetation types in the vicinity of the study area, Hawaii (after Jacobi 1989). 
ORNL-DWG 95-5966

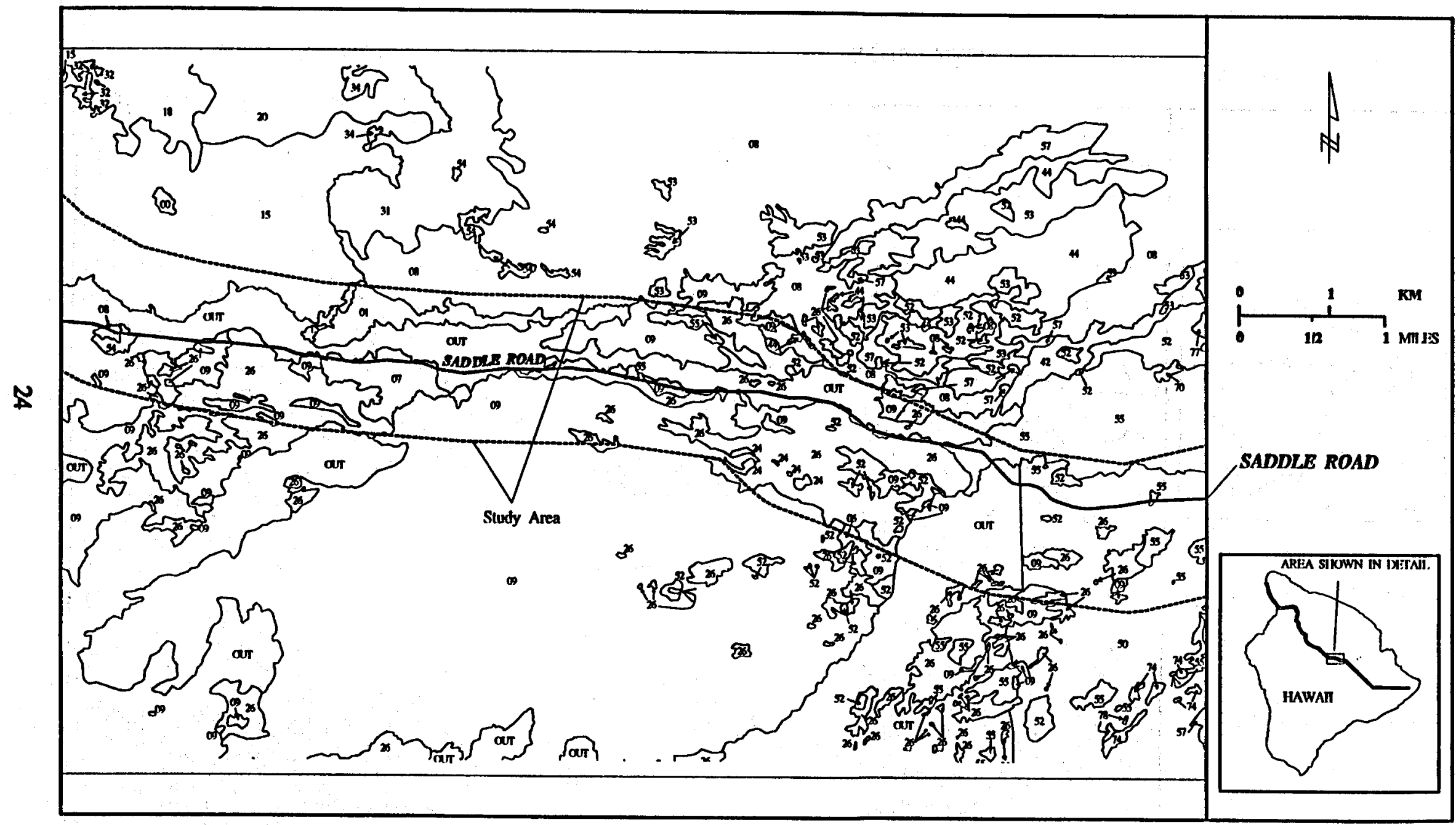

Fig. 3d. Vegetation types in the vicinity of the study area, Hawaii (after Jacobi 1989). 


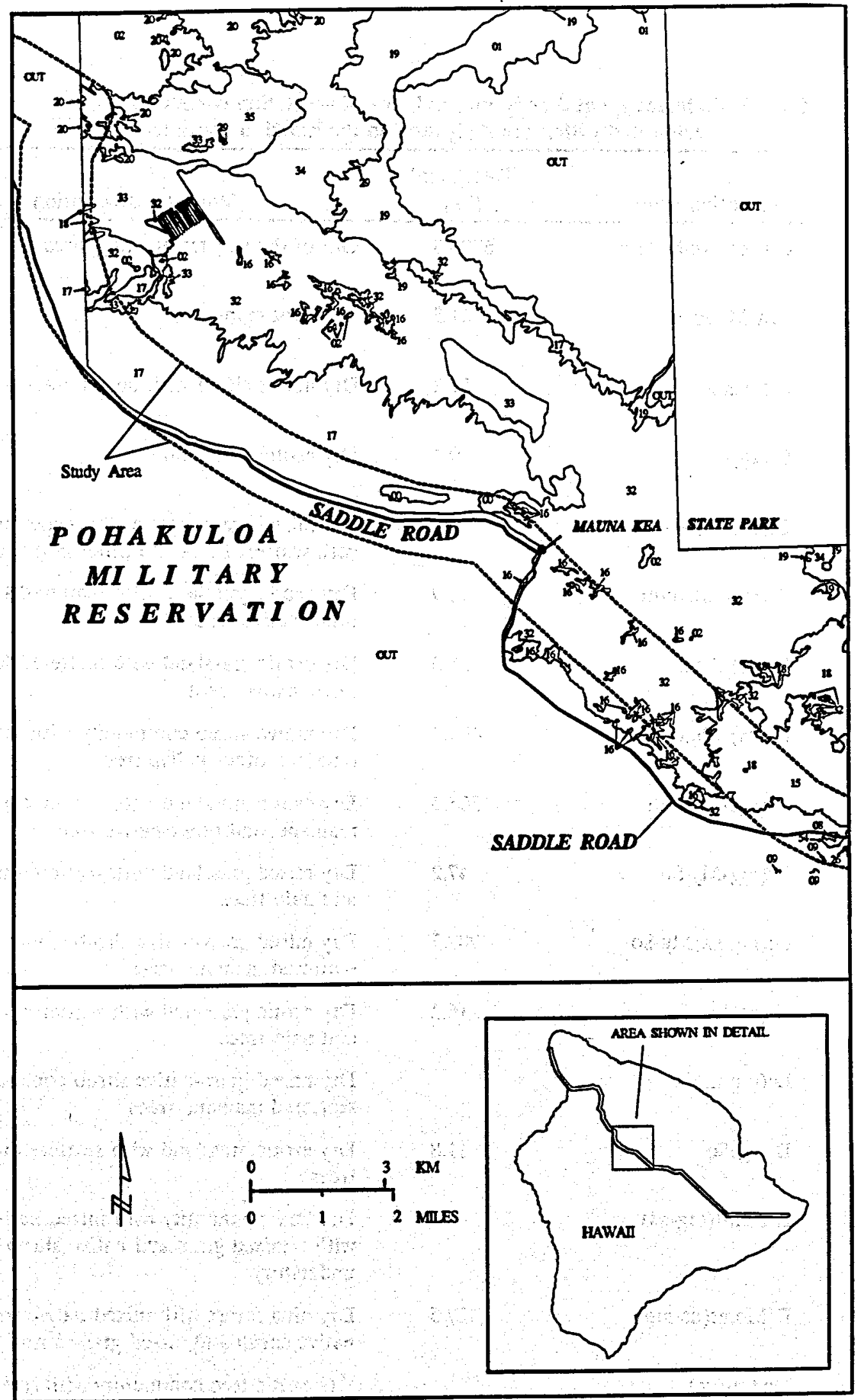

Fig. 3e. Vegetation types in the vicinity of the study area, Hawaii (after Jacobi 1989). 
Table 8. Code, map unit description, and area of vegetation community types delineated within the study area on the island of Hawaii

\begin{tabular}{|c|c|c|c|}
\hline Map unit ${ }^{\circ}$ & Vegetation code & $\begin{array}{l}\text { Total areab } \\
\text { (ha) }\end{array}$ & Map unit description \\
\hline OUT & Out of Study Area & 6703.6 & Out of the vegetation study area \\
\hline $\mathbf{\infty}$ & Not Mapped & 61.5 & Area not mapped \\
\hline 01 & D:(ns,mg) & 57.2 & Dry native shrub with mixed grass community \\
\hline 02 & $\mathrm{D}:(\mathrm{xg})$ & 9.4 & Dry exotic grassland \\
\hline 06 & $D:(m g, n s) A c-n t$ & 1.9 & $\begin{array}{l}\text { Dry mixed grass, native shrub community } \\
\text { with scattered koa and other native trees }\end{array}$ \\
\hline 07 & $D:(m g-n s) A C-n t$ & 58.9 & $\begin{array}{l}\text { Dry exotic grassland with scattered koa and } \\
\text { other native trees }\end{array}$ \\
\hline 08 & D:(xg) Ac-nt & 65.0 & $\begin{array}{l}\text { Dry exotic grassland with scattered koa and } \\
\text { other native trees }\end{array}$ \\
\hline 09 & D:(ns) Me,nt & 409.7 & $\begin{array}{l}\text { Dry native shrub community with scattered } \\
\text { ohia and other native trees }\end{array}$ \\
\hline 15 & D:(xg)Ac-So,nt & 505.3 & $\begin{array}{l}\text { Dry exotic grassland with scattered koa, } \\
\text { mamane, and other native trees }\end{array}$ \\
\hline 16 & D:(mg)My-So & 47.2 & $\begin{array}{l}\text { Dry mixed grassland with scattered mamane } \\
\text { and naio trees }\end{array}$ \\
\hline 17 & D:(mg-ns)My-So & 982.7 & $\begin{array}{l}\text { Dry mixed grass-native shrub community with } \\
\text { scattered mamane trees }\end{array}$ \\
\hline 18 & D:(xg)My-So & 16.2 & $\begin{array}{l}\text { Dry exotic grassland with scattered mamane } \\
\text { and naio trees }\end{array}$ \\
\hline 19 & D:(mg-ns)So & & $\begin{array}{l}\text { Dry mixed grass-native-shrub community with } \\
\text { scattered mamane trees. }\end{array}$ \\
\hline 20 & D:(xg)So & 11.8 & $\begin{array}{l}\text { Dry exotic grassland with scattered mamane } \\
\text { trees }\end{array}$ \\
\hline 24 & D:Ac,nt(mg-ns) & 6.4 & $\begin{array}{l}\text { Dry koa community with mixed native trees } \\
\text { with a mixed grass and native shrub } \\
\text { understory }\end{array}$ \\
\hline 26 & D:Me,nt(ns-mg) & 427.5 & $\begin{array}{l}\text { Dry ohia forest with mixed native trees and a } \\
\text { native shrub and mixed grass forest }\end{array}$ \\
\hline 29 & Dxt,nt(xg) & & $\begin{array}{l}\text { Dry exotic tree community with scattered } \\
\text { native trees and an exotic grass understory }\end{array}$ \\
\hline
\end{tabular}




\begin{tabular}{|c|c|c|c|}
\hline Map unit ${ }^{a}$ & Vegetation code & $\begin{array}{l}\text { Total area } \\
\text { (ha) }\end{array}$ & Map unit description \\
\hline 31 & D:Ac-So(xg-ns) & & $\begin{array}{l}\text { Dry mamane-naio scrub forest with a mixed } \\
\text { grass and scattered native shrub understory }\end{array}$ \\
\hline 32 & D:My-So(mg-ns) & 932.4 & $\begin{array}{l}\text { Dry mamane-naio scrub forest with a mixed } \\
\text { grass and native shrub understory }\end{array}$ \\
\hline 33 & D:My,So(xg-ns) & 65.0 & $\begin{array}{l}\text { Dry naio scrub forest with scattered mamane } \\
\text { and an exotic grass and native shrub } \\
\text { understory }\end{array}$ \\
\hline 34 & D:So(mg-ns) & & $\begin{array}{l}\text { Dry mamane woodland with a mixed grass- } \\
\text { native shrub understory }\end{array}$ \\
\hline 35 & D:So(xg,ns) & 59.4 & $\begin{array}{l}\text { Dry mamane woodland with an exotic grass } \\
\text { and scattered native shrub understory }\end{array}$ \\
\hline 42 & M:(ns)pio & 72.0 & Mesic pioneer native shrub community \\
\hline 44 & M:(xg)Ac-Me-nt & 3.4 & $\begin{array}{l}\text { Mesic exotic grassland with scattered koa, } \\
\text { ohia, and other native trees }\end{array}$ \\
\hline 46 & M:(mg,ns)Me-nt & & $\begin{array}{l}\text { Mesic mixed grass and native shrub } \\
\text { community with scattered ohia and other } \\
\text { native trees }\end{array}$ \\
\hline 50 & M:(ns)Me,pio & 371.4 & $\begin{array}{l}\text { Mesic pioneer native shrub community with } \\
\text { scattered scrub ohia trees }\end{array}$ \\
\hline 52 & M:Ac-Me,nt(ns) & 29.4 & $\begin{array}{l}\text { Mesic koa-ohia forest with other native trees } \\
\text { and a native fern and shrub understory }\end{array}$ \\
\hline 53 & M:Ac-Me,nt(ns--xg-xs) & & $\begin{array}{l}\text { Mesic koa-ohia forest with other native trees } \\
\text { and a native-exotic shrub and grass } \\
\text { understory }\end{array}$ \\
\hline 54 & $M: A c, n t(n s-x g)$ & 7.7 & $\begin{array}{l}\text { Mesic koa forest with other native trees and } \\
\text { a native shrub-exotic grass understory }\end{array}$ \\
\hline 55 & M:Me,nt(ns,mf) & 289.9 & $\begin{array}{l}\text { Mesic ohia forest with other native trees and } \\
\text { a native shrub, matted-fern understory }\end{array}$ \\
\hline 57 & M:Me,nt(mf-ns)pio & 387.3 & $\begin{array}{l}\text { Mesic ploneer ohia forest with other native } \\
\text { trees and a matted-fern, native shrub } \\
\text { understory }\end{array}$ \\
\hline 58 & Mxt(ns) & & $\begin{array}{l}\text { Mesic exotic tree with a native shrub } \\
\text { understory }\end{array}$ \\
\hline 64 & W:(mg-ns) & & $\begin{array}{l}\text { Wet mixed grass-rush-sedge and native shrub } \\
\text { community }\end{array}$ \\
\hline
\end{tabular}


Table 8 (continued)

\begin{tabular}{|c|c|c|c|}
\hline Map unit & Vegetation code & $\begin{array}{c}\text { Total areab } \\
\text { (ha) }\end{array}$ & Map unit description \\
\hline 69 & W:(tf,ns)Me-nt & 485.4 & $\begin{array}{l}\text { Wet treefern and native scrub community } \\
\text { with scattered ohia and other native trees }\end{array}$ \\
\hline 70 & W:(mf/ns)Me-nt & 7.9 & $\begin{array}{l}\text { Wet matted fern and/or native shrub } \\
\text { community with scattered ohia and other } \\
\text { native trees }\end{array}$ \\
\hline 72 & W:(mf-ns-xs)Me-xt & & $\begin{array}{l}\text { Wet matted fern, native and exotic shrub } \\
\text { community with scattered ohia and exotic } \\
\text { trees }\end{array}$ \\
\hline 74 & W:Ac-Me,nt(tf,ns) & & $\begin{array}{l}\text { Wet koa-ohia forest with other native trees } \\
\text { and a treefern, native shrub understory }\end{array}$ \\
\hline 77 & W:Me,nt(tf,ns) & 3384.1 & $\begin{array}{l}\text { Wet ohia forest with other native trees and a } \\
\text { treefern, native shrub understory }\end{array}$ \\
\hline 78 & W:Me,nt(ns/mf) & 163.9 & $\begin{array}{l}\text { Wet ohia forest with other native trees and } \\
\text { native shrubs/matted ferns }\end{array}$ \\
\hline 79 & W:Me,nt(ns-xg/xs) & 213.6 & $\begin{array}{l}\text { Wet ohia forest with other native trees and a } \\
\text { native shrub-exotic grass and shrub } \\
\text { understory }\end{array}$ \\
\hline 80 & W:Me(mf,ns)pio & 284.0 & $\begin{array}{l}\text { Wet pioneer ohia forest with a matted fern } \\
\text { and a native shrub understory }\end{array}$ \\
\hline 81 & Wxt,Me(mf-ns) & 55.5 & $\begin{array}{l}\text { Wet exotic tree and ohia forest with a matted } \\
\text { fern and native shrub understory }\end{array}$ \\
\hline
\end{tabular}

"Based on the "intermediate-level" Jacobi classification.

'Classes not having an acreage appear in the figures but not within the transmission corridor boundary. Acreage reported is the amount of area within the transmission corridor boundary only.

Source: Jacobi 1990. 
Vaccinium reticulatum, Coprosma emodeoides, Machaerina angustifolia, Dubautia scabra, and Stereocaulon volcani (Jacobi 1990). Above $2000 \mathrm{~m}$ (6500 ft) dry ohia and shrub communities exist. The dry ohia forests (no. 26; Fig. 3d) have relatively open canopies, with an overstory of ohia, and an understory of Styphelia, Dodonaea, Vaccinium, Dubautia, Deschampsia spp., Carex wahuensis, Machaerina gahniaeformis, and Luzula hawaïensis (Jacobi 1990). Early successional stages of this community (no. 9; Fig. 3d) also exist without an ohia overstory. The scrub and forest communities in this area have few alien species and are relatively undisturbed. Both the road right-of-way and an existing 138-kV transmission line corridor are areas of disturbance that contain alien plant species (unpublished data by G. Gerrish provided to Okahara and Associates in 1991). The road side is vegetated primarily by alien species (e.g., Pennisetum clandestinum) because of the repeated mowing and grading. In contrast, the power line right-of-way was disturbed only during construction of the line, and it is now vegetated by a mixture of native and alien plants (unpublished data by G. Gerrish provided to Okahara and Associates in 1991). Apparently, the native species are able to reestablish on these disturbed sites when disturbance does not reoccur and there is no severe competition from alien plants. According to observations of the occurrence of alien plants in this area, alien species are more competitive, and hence invasive, in the wet zones and much less so in the mesic and xeric zones (unpublished data by G. Gerrish provided to Okahara and Associates in 1991). This phenomenon is particularly evident in forest communities, which are much more susceptible to invasion by alien species than are scrub/forest lands.

At the crest of the saddle $(2000 \mathrm{~m} ; 6500 \mathrm{ft}$ ) and leeward, dry mamane and naio (Myoporum sandwicense)-mamane forests (nos. 15, 16, 32, 33; Fig. 3e) dominate. These community types are open, low-stature woodlands; other trees include Santalum spp. and Euphorbia sp., common native shrubs include Chenopodium oahense, Dodonaea sp., Bidens menziesii, Styphelia sp., Vaccinium sp. and Geranium cuneatum. Ground vegetation includes Deschampsia australis, Eragrostis spp., Agrostis sandwicensis, Asplenium adiantum-nignum, Asplenium trichomanes, and Pellaea ternifolia. The mamane and naio-mamane community types have been disturbed by grazing of feral sheep and goats and domestic and feral cattle. However, these areas are still of relatively high quality (unpublished data by G. Gerrish provided to Okahara and Associates in 1991) and provide important habitat for sensitive species (see Sect. 2.5)

North and west of the Waiki'i Ranch substation the vegetation is dominated by pasture communities and is hence classified as agriculture and range land. These lands support few native plants. Islands or pockets of remnant vegetation can exist within pastures in this area (unpublished data by G. Gerrish provided to Okahara and Associates in 1991). These agricultural lands may have federally protected plant species present (unpublished data by G. Gerrish provided to Okahara and Associates in 1991).

The study area includes habitat for sensitive species and ecologically important areas. Seventeen sensitive plant species and five ecologically important community types are known to occur within the vicinity of the study area. These species and ecologically important communities and habitats are discussed in Sect. 25.1 and 2.5.3, respectively. 


\section{Fauna}

Avifauna. Sixteen species were found in the study area from the GRZ to the Puna substation, including three native species (Table 9) (unpublished data by Fleischer provided to DHM, Inc., in 1987). Both the Hawaiian stilt and the 'Elepaio were observed in the vicinity of the proposed Puna substation location. A pond near the proposed substation location was also used by three migrant species; the northern pintail (Anas acuta), the lesser scaup (Aythya affinis), and the golden plover (Pluvialis dominica).

Table 9. Endemic forest birds, excluding federally listed endangered species, which may occur in the study area

\begin{tabular}{lll}
\hline \multicolumn{1}{c}{ Scientific name } & Common name & \multicolumn{1}{c}{$\begin{array}{c}\text { Vicinity within corridor } \\
\text { study area }\end{array}$} \\
\hline Chasiempis sandwichensis & 'Elepaio & Puna substation, Humuulu Saddle \\
Myadestes obscurus & 'Omao & Humulu saddle \\
Hemignathus virens & Common 'Amakihi & Humulu saddle \\
Vestiaria coccinea & Tiwi & Humulu saddle \\
Himatione sanguinea & 'Apapane & Humulu saddle \\
Asio flammeus sandwichensis & Pueo & Humuulu saddle \\
Buteo solitarius & Hawaiian hawk & Puna substation \\
Himantopus mexicanus knudseni & Hawaiian stilt & Puna substation \\
\hline
\end{tabular}

Source: Scott et al. 1986; Kjargaard 1991; Pratt, Bruner, and Berrett 1989.

The ohia and koa forests within the study area provide excellent habitat for endemic forest birds. Kjargaard (1991) observed 25 species, seven of which were endemic, during an avifauna survey of the proposed water resources transmission corridor, along the Saddle Road. Endemic forest birds, excluding federally listed species, known to be present in the study area are shown in Table 9. In addition to the forest birds, habitat for six federally listed endangered birds and one mammal is present in the area (see Sect. 2.5.2).

Invertebrates. A 1987 survey of invertebrates from the GRZ to the Puna substation showed 44 endemic species, 3 indigenous species, 70 alien species, and 12 species not previously found on island of Hawaii (unpublished data by G. Nishida and W. Gagne provided to DHM, Inc. in 1987). The discovery of 12 new species in a brief survey of disturbed areas suggests that similar discoveries could be made in future surveys of this area. This finding also shows that even areas 
not composed of purely native vegetation can provide habitat for endemic Hawaiian biota. The long-legged ant (Anoplolepis longiceps) was identified as an important predator on native arthropods (unpublished data by G. Nishida and W. Gagne provided to DHM, Inc. in 1987). They also recognized four areas of entomological significance: the Kazumura cave, the Pahoa cave, a kipuka south of Pahoa, and a forested area near the Seaview Road. The caves are important because they provide habitat for unique cave-adapted organisms, some of which exist only in these caves. The forest areas along this segment of the study area are important because they provide a "living laboratory" for the study of the effects of the long-legged ant on native arthropods (unpublished data by G. Nishida and W. Gagne provided to DHM, Inc. in 1987).

Except for the reported occurrences of the Amastrid land snail (Leptachatina sp.) at about 1950-m (6400-ft) elevation west of Pu'u Huluhulu (TNCH 1993), there is no information about invertebrates in above-ground habitats in other portions of the study area. Other surveys of invertebrates in the vicinity of the Saddle Road (Stone 1992) have demonstrated that habitats in this area support endemic species (Table 10). Caves are prevalent along the Saddle Road corridor, particularly on the 1855 and 1881 lava flows. Accordingly, a diverse invertebrate community is likely to be present.

\section{STUDY AREAS ON MAUI AND OAHU}

\subsection{Vegetation}

The study area includes overland segments that traverse the dry southern slopes of Haleakala, Maui and extend inland from the windward shore at Waimanalu, Oahu. The botanical survey conducted by the FWS (Evans, Woodside, and Bruegmann 1994) considered a 100-m-wide (330-ft-wide) corridor.

The dryland forests contain the richest diversity of tree species of all vegetation types in Hawaii (Rock 1913). This vegetation zone has also been most highly disturbed by humans (TNCH 1991). The south slope of Haleakala, Maui, has long been recognized as a dramatic example of both species richness and high disturbance in a dryland forest. Much of the dryland forest zone of Haleakala has been converted to cattle pasture and was already seriously degraded by browsing cattle and goats in 1910 (Rock 1913).

Remnant pockets of native taxa remain in small gullies and other areas inaccessible to cattle and goats or as mature or dying trees that are no longer reproducing. The understory is frequently composed of introduced taxa, typically range grasses (Medeiros, Loope, and Holt 1986). Many rare and endangered taxa are found in this zone (see Sect. 2.5.1).

Most of the lower portion of the dryland forest zone of east Maui has been converted to pasture, although several pockets of native dry shrubland and dryland forest were observed during the FWS field survey (Jacobi et al. 1994). The native vegetation types observed included Wikstroemia monticola (Akia) lowland dry shrub land, Dodonaea viscosa ('A'ali'i) lowland dry shrubland, and Enthrina sandwicensis (Wiliwili) lowland dry forest. These patches of native 
Table 10. Native invertebrates occurring in lava tubes and crack habitats along the study area in the vicinity of the Saddle Road

\begin{tabular}{|c|c|c|}
\hline \multicolumn{3}{|l|}{ Arthrapoda } \\
\hline Crustacea & ? sp. & (Isopoda) \\
\hline Chilopoda & Lithobius & (Lithobiid) \\
\hline Diplopoda & Dimerogonus & (Cambalid) \\
\hline Araneida & Erigone stygius & (Linyphiid) \\
\hline & Oonops & (Oonopid) \\
\hline & Lycosa howarthi & (Lycosid) \\
\hline Insecta & Caconemobius varius & (Gryllid) \\
\hline & C. sp. A & (Gryllid) \\
\hline & C. sp. B ? & (Gryllid) \\
\hline & Thaumatogryllus sp. & (Gryllid) \\
\hline & Oliarus polyphemus? & (Cixiid) \\
\hline & Nesidiolestes ana & (Reduviid) \\
\hline & Schrankia 2+sp. & (Noctuid) \\
\hline & Forcipomyia sp. & (Ceratopogonid) \\
\hline & Limonia cf. jacobus & (Tipulid) \\
\hline & Phytosciara volcanata & (Sciarid) \\
\hline & Mycetophilidae & (Mycetophilid) \\
\hline
\end{tabular}

Note: "?" indicates uncertain classification.

Source: Stone 1991.

lowland vegetation are scattered throughout the area and are all that remains of the original vegetation of the lower dryland zone of east Maui. $E$. sandwicensis has been declining in number since at least the early 1900s (Rock 1913).

The windward low-elevation area designated as the study area on Oahu extends from the shore near Waimanalo to a site at the eastern base of the Koolau mountain range (Krasnick and Mansur 1987). This areas is highly disturbed by development, and the vegetation communities consist mainly of alien species. A search of the Hawaii Heritage Program (HHP) database in 1993 did not show any endangered or threatened plants in this area. 


\subsection{Fauna}

Wetlands (see Figs. 4 and 5) in the vicinity of the study area on the islands of Maui and Oahu provide habitat for four endangered waterbirds (Evans, Woodside, and Bruegmann 1994) (see Sects. 2.4 and 2.5). The dryland vegetation communities in the study area on Maui provide habitat for cattle and rodents that are characteristic of disturbed agricultural areas in Hawaii (see Sect. 2.4.2.2).

\section{WETLAND RESOURCES}

Wetland resources in the vicinity of the geothermal study areas generally include swamps, marshes, bogs, and similar areas. The federal criteria for identifying these wetlands are provided by the U.S. Army Corps of Engineers (COE) Wetlands Delineation Manual (COE 1987). Most identification and study of wetlands on Hawaii have been in coastal areas (e.g., Elliott and Hall 1977), which are extremely important for water bird habitat. A recent survey of water bird use in the study area on Oahu and Maui provides current information on these resources (Evans, Woodside, and Bruegmann 1994). The only inland wetlands that have been studied are montane bogs.

Whether low-elevation rain forests contain wetlands (i.e., sites with soils, vegetation, and hydrologic properties that satisfy the Wetlands Delineation Manual) is of special interest because portions of the rain forest ecosystem exhibit properties and functions similar to wetlands (Lee 1992). A study of the applicability of the wetland criteria to low-elevation rain forests was conducted by COE (1987). The following discussion summarizes current information on wetland resources within the GRZ and the other parts of the study. This discussion is based on published literature and results of the COE (Wakeley, Sprecher, and Lichvar 1994) and FWS (Evans, Woodside, and Bruegmann 1994) studies.

\subsubsection{Rain Forest Wetlands}

Wetland identification is based on the presence of characteristic hydrology, soil properties, and vegetation. Results from the COE survey (Wakeley, Sprecher, and Lichvar 1994) of those diagnostic criteria demonstrated that the usual approaches for identifying wetlands often were not adequate and that frequently, areas exhibiting some wetland characteristics would not satisfy the jurisdictional criteria. The difficulty of recognizing wetlands in the rain forest was attributed to (1) the fact that the delineation manual was developed for the continental United States, (2) the lack of applicable diagnostic soils and vegetation criteria to rain forest conditions, and (3) the difficulty in accessing field sites. Despite these difficulties, the COE report clearly showed that jurisdictional wetland areas do exist within the low- to mid-elevation ohia rain forest community types. Wetland areas are usually "wet pockets" that range in size from 10 to $1000 \mathrm{~m}^{2}\left(110\right.$ to $\left.11,000 \mathrm{ft}^{2}\right)$; but 
ORNL-DWG 94M-1450

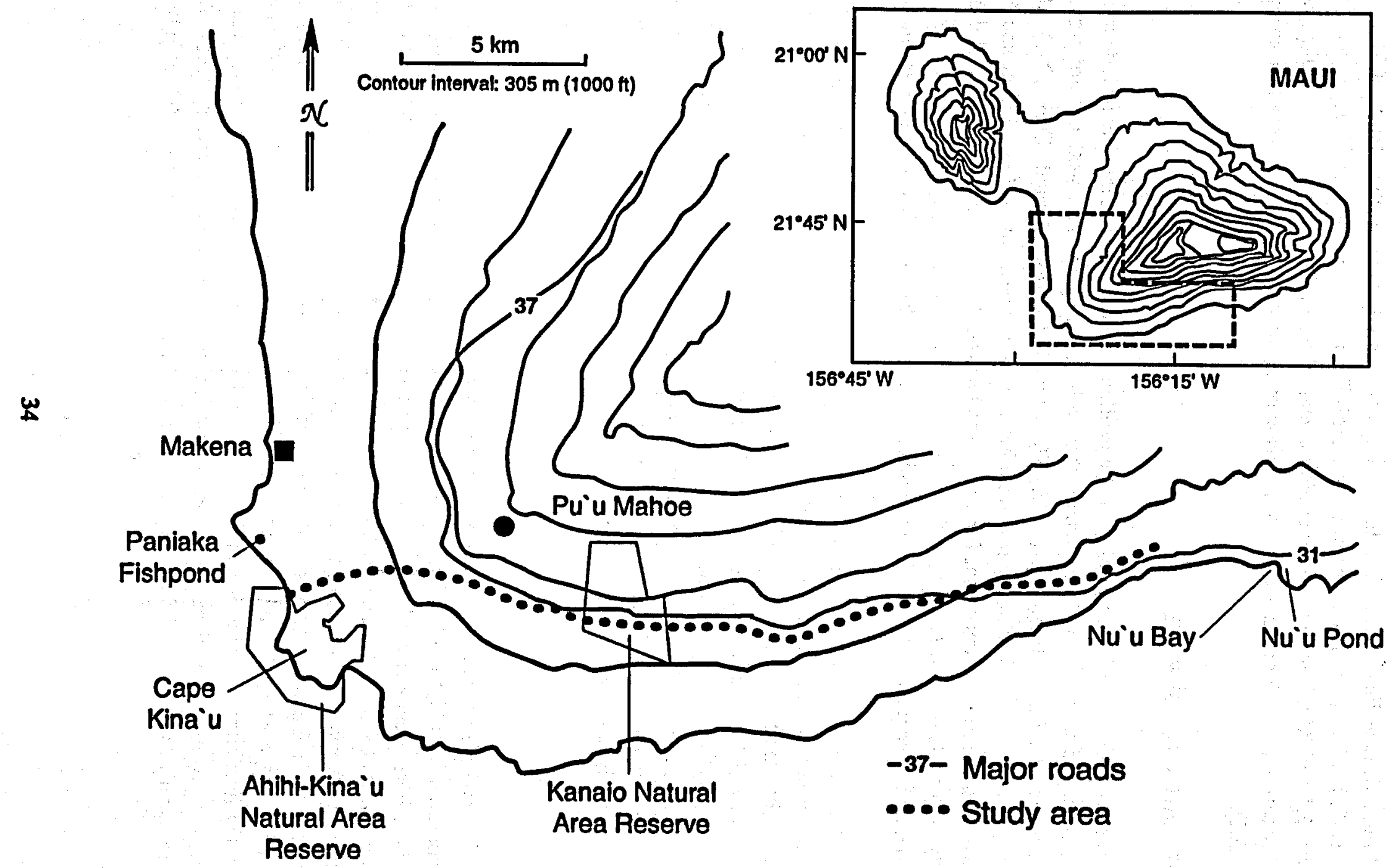

Fig. 4. Coastal wetlands in the vicinity of the study area, Maui. Source: Evans, Woodside, and Bruegmann 1994. 
ORNL-DWG-94M-1449

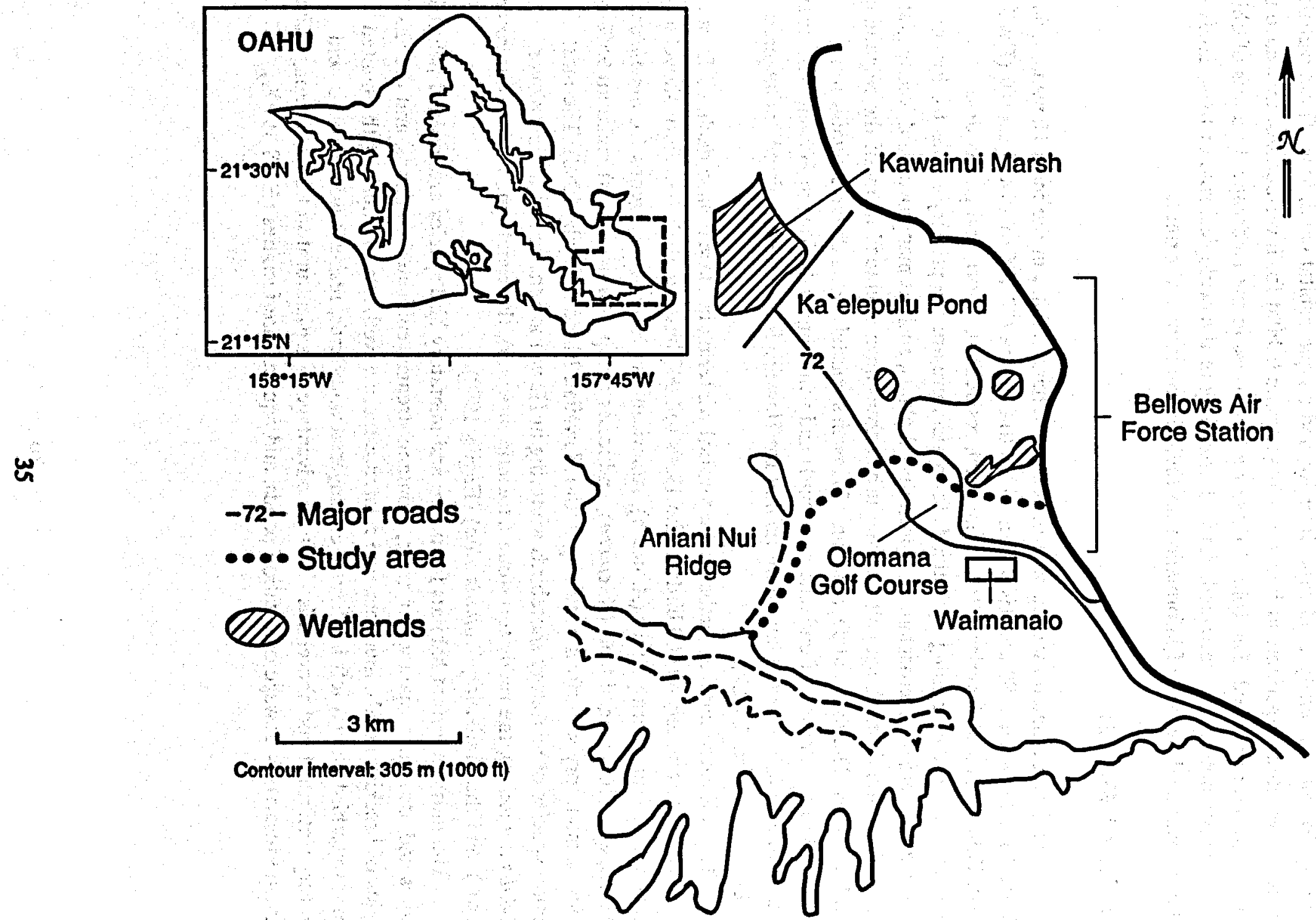

Fig. 5. Coastal and inland wetlands in the vicinity of the study area, Oahu. Source: Evans, Woodside and Bruegmann 1994. 
larger wetland areas may also exist. Unfortunately, wetland areas are not consistently recognizable by aerial survey and therefore must be identified through ground surveys.

Wetland sites within the ohia rain forest serve important ecological functions that include providing biological diversity, landscape diversity, and unique habitat conditions. These wetlands may also serve other functions, such as providing aquatic habitat for invertebrates, that have not been recognized or studied. The role of these wetland areas in the landscape dynamies of ohia rain forests has not been determined. An understanding of the ecological role of these lands is further constrained by lack of information on their distribution and extent.

\section{Coastal Wetlands}

FWS has estimated that the area of coastal wetland habitat in the main Hawaiian Islands declined $31 \%$ between 1780 and 1980 [from 9096 to 6262 ha (22,475 to 15,474 acres)] (FWS 1990a). Filling of coastal wetlands for commercial, residential, resort, and golf course developments and the draining of wetlands for agriculture are the primary causes for loss of coastal wetland areas. Encroachment of introduced plants, such as mangroves and weedy grasses, and runoff from industrial, agricultural, and urban areas have degraded many of the remaining coastal wetlands. The loss and degradation of Hawaii's coastal wetlands have significantly contributed to the decline of endemic waterbirds and wintering waterfowl in Hawaii. The coastal wetlands that remain provide important habitat for Hawaii's four federally listed endangered waterbirds (see Sect. 2.5.2.2).

The estimated annual numbers of waterfowl wintering in Hawaii have declined from an average of approximately 40,000 birds in the 1950 s to 2000 birds in 1990 . Northern shovelers (Anas clypeata), northern pintails (A. acuta), American and Eurasian widgeons (A. americana and A. penelope), green-winged teals (A. crecca), and lesser scaup (Aythya affinis) make up 95\% of the species of migratory waterfowl wintering in the Hawaiian Islands (Engilis 1988). The most common species of migratory shorebirds wintering in Hawaii are the lesser golden-plover (Pluvialis dominica), the ruddy turnstone (Arenaria interpres), the wandering tattler (Heteroscelus incanus), and the sanderling (Calidris alba) (Engilis 1988).

The most important habitats for native and migratory bird species are lowland palustrine marshes and associated open water areas, montane streams, cultivated wetlands, and the shallow margins of brackish ponds, mudflats, and related estuarine wetlands. Because of the limited natural waterbird habitat left in Hawaii, endangered waterbirds, resident wading birds, and migratory waterfowl and shorebirds also take advantage of agricultural wetlands, drainage ditches, manmade reservoirs, sewage oxidization ponds, and aquaculture facilities (FWS 1990b). 


\subsection{Wetlands in the vicinity of the Geothermal Resource Zone, island of Hawaii}

In their survey of Hawaiian wetlands, Elliott and Hall (1977) identified three coastal wetlands in the vicinity of the GRZ. These three wetlands are known as Lokoaka and Kionakapahu ponds, Haena Marsh, and Kapoho fishpond (Fig. 6).

The Lokoaka and Kionakapahu freshwater ponds are located in northeast Hilo, less than $3.2 \mathrm{~km}$ ( 2 miles) from the Hilo Airport. These ponds are characterized by open water with marsh vegetation primarily at the pond edges, between the ponds, and in patches south of Lokoaka Pond. Vegetation is dominated by California grass (Elliott and Hall 1977). The Haena Marsh is located $16 \mathrm{~km}$ (10 miles) southeast of Hilo in the Kea'au Ranch at Haena. This marsh consists of a spring-fed pond and adjacent wetland vegetation. Marsh vegetation is mixed but is generally characterized by grasses and sedges such as broad-leaved carpet grass (Axonopus fissifolive), Glenwood grass (Sacciolepis indica), California grass, and eleocharis (Eleocharis geniculata). Near the pond, water hyacinth (Eichhomia crassipes) and great bulrush (Scirpus validus) are abundant. Water hyacinth, California grass, and papyrus (Cyperus papyrus) formerly covered the pond and are now cleared regularly to control their spread. Much of the southern pond is grazed by cattle. Waterfowl have been observed in this wetland (Elliott and Hall 1977). The Kapoho fishpond is located in a bay near Kapoho Point on the eastern tip of Hawaii, approximately $1.6 \mathrm{~km}$ (1 mile) east of the Kapoho GRZ. The wetland is dominated by scattered thickets of American mangrove (Rhizophora mangle) that surround small areas of brackish, open water and almost pure stands of seashore paspalum (Paspalum vaginatum). One state-listed sensitive species, known as pue'o or the short eared owl (Asio flammeus sandwichensis), has been observed in the wetland area (Elliott and Hall 1977).

\subsection{Wetlands in the vicinity of the study area, Maui}

Three wetlands in the vicinity of the study area on Maui are recognized: the Paniaka Fishpond, the Ahihi-Kina'u Natural Area Reserve anchialine ponds, and the Nu'u Pond (Fig. 4). The following information is summarized from Evans, Woodside, and Bruegmann (1994).

Paniaka Fishpond. Paniaka Fishpond is located adjacent to Big Beach along the ocean side of the Mákena-Keone'o'io Government Road just south of Makena. The wetland covers approximately 0.4 ha ( 1 acre) and is owned by the state of Hawail. The pond consists of a shallow depression of slightly brackish water with sparse emergent vegetation growing within and along the edges of the pond. Kiawe trees (Prosopis pallida) dominate the surrounding upland.

Hawaiian stilts and golden plovers have been observed at the pond-six in 1992 and three in 1993, respectively. One plover was observed there in 1993. HHP does not have occurrence records for any endangered Hawaiian waterbirds or migratory shorebirds or waterfowl at Paniaka Fishpond. Paniaka Fishpond is included in the state's annual waterbird counts (DLNR 1993).

Ahihi-Kina'u Natural Area Reserve (NAR) anchialine ponds. The Ahihi-Kina'u NAR is the site of the most recent lava flow on the island of Maui and contains anchialine pook, known 


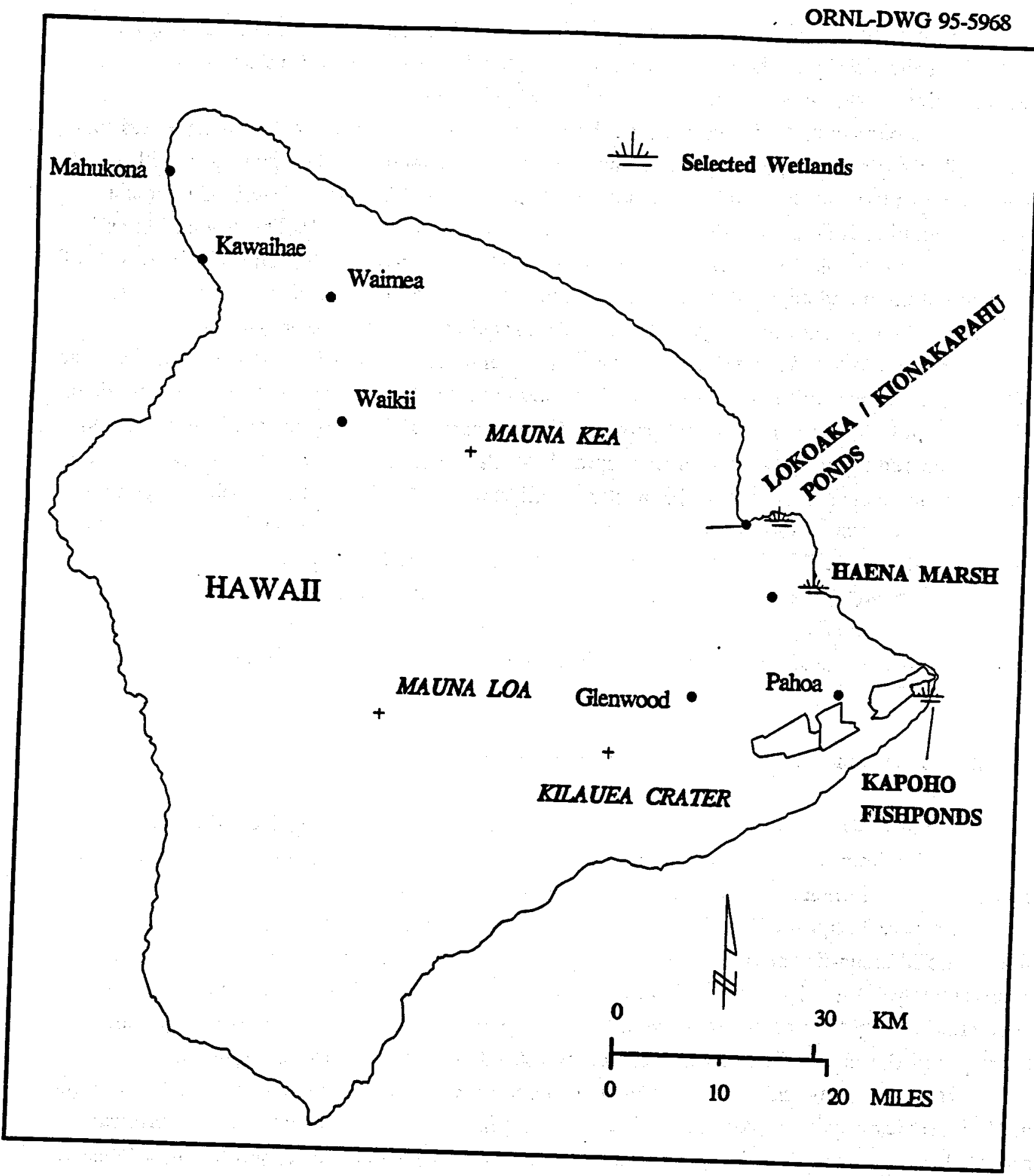

Fig. 6 Coastal wetlands in the vicinity of the study area on the island of Hawait Elliott and Hall 1977. 
for their high diversity of rare Hawaiian shrimps, and a unique lava tube community that provides habitat for native Hawaiian cave animals (TNCH 1989a). Anchialine pools are distributed along the Cape Kina'u peninsula seaward of the Makena-Keone'o'io Government Road, at varying distances from the sea between Nuku'ele Point on the Cape and La Perouse Bay (Wong 1975). Maciolek (1986) separated the pools into 12 groups in order to describe the pools in terms of distribution, basin character, water quality, and aquatic biota. Each group consisted of a few to many pools in close proximity, the groups being separated by either considerable distance, lava of high relief, or a combination of both features. Individual pools vary in surface area from less than $1 \mathrm{~m}^{2}$ to $3000 \mathrm{~m}^{2}$ (11 to $32,000 \mathrm{ft}^{2}$ ), most of them being very small. Total water surface area of the groups ranges from a few square meters to more than $2000 \mathrm{~m}^{2}\left(22,000 \mathrm{ft}^{2}\right)$. Most pools are less than $0.5 \mathrm{~m}$ (1.6 ft) deep; the exception is Hă'ula Pond, which exceeds $5 \mathrm{~m}$ (16.4 ft) in depth. Water surface area and depth of the pools are affected by tides, and many of the shallower pools are temporarily drawn down at low tide (Maciolek 1986).

The two most prominent anchialine pools at Ahihi-Kina'u NAR, Ha'ula Pond, and Kauhioaiakini Pond, have recently been surveyed (Fig. 4). Kauhioaiakini Pond is actually a series of pools within a large depression that is the single largest open area of little physical relief on the Cape Kina'u peninsula (Wong 1975). Emergent vegetation-including small rush (Juncus sp.), sea purslane (Sesuvium portulacastrum), and pickelweed (Batis maritima)-occurs along the edges of the pond. Widgeon grass (Ruppia maritima) and several species of blue-green and red algae are abundant in the pond (Wong 1975; Maciolek 1986).

Three adult Hawaiian stilt, three wandering tattlers, and four ruddy turnstones were observed foraging along the banks of Kauhioaiakini Pond during the 1993 FWS survey (Evans, Woodside, and Bruegmann 1994). Other surveys of the pond by HHP reported five Hawaiian stilts on May 2, 1987, and two on March 3, 1988, foraging at the edges of Kauhioaiakini Pond. Wandering tattlers and ruddy turnstones were also recorded during these surveys. The state waterbird surveys do not currently include Kauhioaiakini Pond. However, during the winter waterbird count on Maui in 1981, five Hawaiian stilts were observed at the pond (TNCH 1993a). These survey results are consistent with observations by NAR staff, who report that it is common to see three to five stilts foraging at the pond. No observations of stilt nesting activity have been recorded at the pond (Evans, Woodside, and Bruegmann 1994).

Ha'ula Pond is the single largest water exposure on Cape Kina'u (Wong 1975). Several small patches of pickelweed and rush are found along the shallow-water edges of the pond. A few kiawe trees are found along the ocean shoreline of the pond. Large areas of Indian marsh fleabane (Pluchea indica) dominate the inland shoreline of the pond. Macroflora of the pond are dominated by green and blue-green algae (Maciolek 1986). Widgeon grass occurs on crust-covered rocks protruding into the water (Wong 1975).

No endangered waterbirds or migratory shorebirds were observed at Ha'ula Pond by FWS biologists during the September 1993 survey. The HHP has no records of endangered waterbirds or migratory shorebirds at the pond. The state waterbird surveys do not include Háula Pond. 
Nu'u Pond. Nu'u Pond or Salt Pond is a privately owned pond located inland of Nu'u Bay along the southern coastline of east Maui (Fig. 4). The pond is perennial and is apparently used as a cattle stock pond. Livestock use of the pond limits the growth of wetland vegetation within and along the edges of the pond. The pond covers approximately 0.2 ha ( 0.5 acre).

FWS biologists observed 3 adult Hawaiian stilts, 17 adult Hawaiian coots, and 8 Hawaiian coot chicks in Nu'u pond on September 21, 1993. One Hawaiian coot nest with eggs was also observed. The HHP does not have any records of endangered waterbirds or migratory shorebirds or waterfowl at Nu'u Pond. The annual state waterbird counts include information on Nu'u Pond for the winter and summer counts of 1992 and the summer count of 1993 . During the 1992 winter count, 56 Hawaiian coots, 6 Hawaiian stilts, 14 Northern pintails, 4 ruddy turnstones, and 1 wandering tattler were observed at Nu'u Pond. During the summer count at the pond in the same year, 44 Hawaiian coots and 5 Hawaiian stilts were observed. During the 1993 winter count, 28 Hawaiian coots, 3 Hawaiian stilts, 2 lesser golden plovers, 1 ruddy turnstone, and 3 wandering tattlers were observed at the pond (DLNR 1993). Nu'u Pond is identified by the FWS draft revised Hawaiian Waterbirds Recovery Plan as an area where long-term protection through a cooperative effort with the landowner should be explored.

\subsection{Wetlands in the vicinity of the study area, Oahu}

There are five wetlands in the vicinity of the study area on Oahu: the Waimanalo stream wetland, the Bellows Air Force Station wetland, the Olomana Golf Course wetland, Ka'ellepulu Pond, and Kawainui Marsh (Fig. 5). The following description of these wetlands is derived from Evans, Woodside, and Bruegmann (1994).

Waimanalo stream wetland. Waimannalo Stream, which originates near the base of the Ko'olau Mountains, flows through agricultural and rural areas of Waimanalo, crosses the Kalaniana'ole Highway, passes through Bellows Air Force Station, and discharges to the ocean at Bellows Beach. The stream is channeled below the Kalaniana'ole Highway. Portions of the stream within Bellows Air Force Station are bordered by mangrove trees in the lower reaches and disturbed areas of upland in the upper reaches. Several shallow mudflat areas occur along the upper reaches of the channelized portions of the stream. An old oxbow exists along the lower reaches of the stream near its outlet to the ocean. The oxbow has filled in with sediment and formed a small [ 1 ha (2.5 acres)] wetland consisting of mangrove trees and a Batis maritima (Pickleweed) flat.

The mangrove wetlands and adjacent shallow stream areas provide suitable foraging and loafing sites for black-crowned night herons and migratory shorebirds. The mudflat areas in the upper reaches of the channelized stream provide loafing and feeding habitat for Hawaiian stilts, herons, and migratory shorebirds. During the recent FWS survey of the area (Evans, Woodside, and Bruegmann 1994), 4 wandering tattlers, 1 black-crowned night heron, 2 stilts, and 13 lesser golden plovers were observed foraging on mudflats within the stream. 
The Batis-dominated portion of the oxbow wetland is generally overgrown and too dense to provide year-round habitat for endangered waterbirds or wintering habitat for migratory waterfowl. However, several small pockets of open water that occur within the wetland are likely to be used by stilts, black-crowned night herons, and shorebirds for feeding. No birds were observed within the Batis or mangrove portions of the oxbow wetland during the FWS survey.

Bellows Air Force Station wetland. A 4-ha (10-acre) isolated, freshwater marsh occurs adjacent to the abandoned air field in the northern section of the Bellows Air Force Station (Fig. 5). This seasonally flooded marsh is currently choked with para grass (Brachiariamutica) and probably provides habitat for endangered waterbirds only after major storm events that generate enough rainfall or stormwater runoff to create ponded areas of open water within the marsh. The marsh is identified as a potential wildlife enhancement area in the FWS Plan and the corresponding environmental assessment for the Bellows Air Force Station (USAF 1975a,b).

The marsh has not been surveyed during annual state waterbird surveys, and the HHP does not have occurrence records for any waterbirds in this area. No endangered waterbirds, resident wading birds, or migratory shorebirds or waterfowl were observed within this marsh by FWS biologists during their 1993 survey (Evans, Woodside, and Bruegmann 1994).

Olomana Golf Course wetland. Olomana Golf Course lies west of Bellows Air Force Station in Waimannalo (Fig. 5). A few of the golf course water hazards and detention ponds provide habitat for endangered Hawaiian waterbirds. During 1993, FWS biologists observed Hawaiian coots and Hawaiian moorhens at the golf course ponds. The ponds at Olomana Golf Course are included in the annual state waterbird surveys. The surveys confirm that small numbers of Hawaiian coots, Hawaiian moorhens, and Hawaiian stilts use the golf course ponds. Other waterbirds observed at the ponds during the state surveys include black-crowned night herons, mallards, and domestic ducks (DLNR 1993).

Ka'elepulu Pond. Ka'elepulu Pond is an urban wetland located within the town limits of Kailua on the windward side of Oahu (Fig. 5). Ka'elepula Pond and its associated wetlands once provided highly productive habitat for all four of Hawaii's endangered waterbirds and valuable wintering habitat for migratory shorebirds and waterfowl Incremental filling of the shallow wetland habitats for urban development has decreased the habitat available to these species. Nevertheless, the remaining wetlands of Káelepula Pond still support small numbers of all four endangered waterbirds and migratory shorebirds and waterfowl. During 1993, Hawaiian coots, Hawaiian moorhens, and Hawaiian stilts at Ka'elepula Pond were observed (Evans, Woodside, and Bruegmann 1994). Káelepula Pond is included in the state's annual waterbird surveys, and all four endangered waterbirds have been consistently observed in small numbers during the surveys over the past 10 years. Small numbers of lesser golden plovers, sanderlings, ruddy turnstones, wandering tattlers, and northern shovelers have been sighted occasionally at the pond during these surveys (DLNR 1993).

Kawainui Marsh Kawainui marsh is a 303-ha (750-acre) freshwater wetland located on the windward coast of Oahu between Kailua Bay and the base of the Ko'olau Mountains (Fig. 5). The marsh is densely vegetated, and areas of open water are limited to the center of the marsh. 
Kawainui marsh provides essential nesting, feeding, and loafing habitat for all four endangered waterbirds. All four species are considered permanent residents of the marsh.

Kawainui marsh also provides habitat for resident wading birds and migratory shorebirds and waterfowl. Migratory waterfowl are found within the open water areas during winter months. Migratory waterfowl reported from Kawainui marsh include northern pintails, northern shovelers, mallards, lesser scaup, green-winged teal, and American widgeon (Engilis 1988). Migratory shorebirds reported from Kawainui marsh include the lesser golden plover, ruddy turnstone, sanderling, and wandering tattler (Shallenberger 1977; Conant 1981; Engilis 1988; Engilis and Pratt 1993). Black-crowned night herons are commonly seen foraging along the edges of the open-water areas and potholes within the marsh. Kawainui marsh is included in the state's annual waterbird surveys. Records of the surveys over the past 10 years corroborate the above information (DLNR 1993).

\section{THREATENED AND ENDANGERED SPECIES}

\subsection{Plants}

\subsubsection{Geothermal Resource Zone and other study areas in Hawaii}

Twenty-five plant species listed as endangered or proposed to be listed as endangered by the FWS have been documented (TNCH 1993) as being present in the study area (Table 11). The HHP data (TNCH 1993) represent only the reported occurrence of an endangered species and not the distribution of the species.

Each of the seven endangered plant species known to occur in the GRZ were in the Kilauea subzone. Adenophorus periens is an endemic fern that once was common in low elevation rain forests. Today only two populations exist, a small one on Molokai and another in the Puna district on the island of Hawaii. This fern is an epiphyte which grows in moss adhering to the lower trunks of ohia. Habitats are usually only found in ohia/fern forests that have sufficient canopy development to encourage the establishment of mosses (Lamoureux et al. 1985). Within the Kilauea subzone $A$. periens was reported in an ohialfern alien subcanopy forest, demonstrating that the plant may exist in community types other than the ohia/fern forest. Accordingly, any wet ohia forests with a well-developed ohia canopy and hapu'u fern (Cibotium spp.) should be considered potential habitat. The ferm Phyllostegia floribunda has been found in the same vicinity as A. periens within the Kilauea subzone (TNCH 1993).

In the western portion of the Kilauea subzone Gardenia remyi, Phyllostegia floribunda, Joinvillea acendens and Bobea timonioides occur within the ohialfern alien subcanopy forest type. Bobea timonioides is a tree of medium stature found in all ohia forest types (Lamoureux et al. 1985). Within the GRZ it has been reported to occur east of Pu'u Kauka and immediately outside the northwestern corner of the subzone. Phyllostegia vestita and Cyanea tritomantha occur in 
Table 11. Threatened and endangered plant species within the study area on Hawaii

\begin{tabular}{|c|c|c|c|c|}
\hline \multirow{2}{*}{\multicolumn{2}{|c|}{ Common name(s) }} & \multirow[b]{2}{*}{$\begin{array}{l}\text { Listing } \\
\text { status }\end{array}$} & \multicolumn{2}{|c|}{ Location } \\
\hline & & & GRZ $^{b}$ & $\begin{array}{l}\text { Other } \\
\text { areas }\end{array}$ \\
\hline Adenophorus periens & & C1 & $\mathbf{x}$ & \\
\hline Asplenium fragile spp. insulare & & PE & & $\mathbf{x}$ \\
\hline Asplenium hobdyi & & $*$ & & $\mathbf{X}$ \\
\hline Bobea timonioides & Ahakea & $\mathbf{C 2}$ & $\mathbf{x}$ & \\
\hline Clemontia pyrularia & Oha, Oha wai & PE & & $\mathbf{X}$ \\
\hline Cyanea platyphylla & 'Oha, Haha, 'Oha wai & $\mathbf{C 3}, *$ & $\mathbf{x}$ & $\because$ \\
\hline Cyanea tritomantha & $\begin{array}{l}\text { 'Oha, Haha, 'Oha wai, } \\
\text { 'Aku'aku, 'Aku }\end{array}$ & $\mathbf{C l}$ & $\mathbf{x}$ & \\
\hline Eunya sanwicensis & Anini, Wanini & $\mathbf{C 2}$ & & $\mathbf{X}$ \\
\hline Gardenia remyi & Nanu, Na'u & $\boldsymbol{C Z}$ & $\mathbf{X}$ & $\mathbf{X}$ \\
\hline Haplostachys haplostachya & & $\mathbf{E}$ & & $\mathbf{x}$ \\
\hline $\begin{array}{l}\text { Joinvillea ascendens ssp. } \\
\text { ascendens }\end{array}$ & Ohe & $\mathbf{C} 2$ & $\mathbf{x}$ & $\mathbf{x}$ \\
\hline Lipochaeta venosa & Nehe & $\mathbf{E}$ & & $\mathbf{x}$ \\
\hline Phyllostegia floribunda & & $*$ & $\mathbf{X}$ & \\
\hline Phyllostegia vestita & 'Ul'ihi & $*$ & $\mathbf{x}$ & $\mathbf{X}$ \\
\hline Plantago hawaiensis & 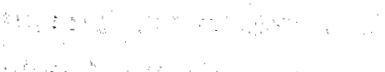 & PE & & $\mathbf{x}$ \\
\hline Portulaca villosa & Thi & $\mathbf{C 2}$ & ? & $\mathbf{X}$ \\
\hline Ranunculus hawaiensis & Makou & $\mathbf{C 2}$ & & $\mathbf{X}$ \\
\hline Scaevola kilaueae & $\begin{array}{l}\text { Naupaka, Kilauea } \\
\text { naupaka }\end{array}$ & $\mathbf{C l}_{\mathbf{1}}$ : & $\mathbf{x}$ & \\
\hline Sicyos macrophyllus & 'Anunu, Kupala & $\mathbf{C 2}$ & & $\mathbf{X}$ \\
\hline Solanum incompletum & & Cl & & $\mathbf{x}$ \\
\hline Stenogyne microphylla & & $\mathbf{C B}_{\mathbf{2}}$ & & $\mathbf{x}$ \\
\hline Stenogyne scrophularioides & & $\mathbf{C}$, & $\mathbf{X}$ & \\
\hline $\begin{array}{l}\text { Tetramolopium arenarium spp } \\
\text { arenarium var. confertum }\end{array}$ & & PE & & $\mathbf{x}$ \\
\hline Vicia menziesii & & $\mathbf{E}$ & $\mathbf{X}$ & \\
\hline Vigna owahuensis & Oahua vigna & C1 & & $\mathbf{X}$ \\
\hline
\end{tabular}

Tisting status: $\mathbf{E}=$ federally listed endangered; PE = propased endangered (federal); $C 1$ = candidate 1 species (federal); $C 2=$ candidate 2 species (federal); $C 3=$ no bonger federally listed; $\bullet=$ not federally listed but recommended as rare by Hawailan biologist; and listed by HPP as either G1 (critically imperiled), G2 (imperiled), or G3 (very rare).

'GRZ = Geothermal Resource Subzone.

'Other areas = see introductory text in Sect. 2.2

Source: TNCH 1993. 
association with $B$. timonioides in the west central portion of the GRZ. The ohialfern forests and ohialfern with alien subcanopy forests are the vegetation types most likely to contain these endangered species.

The Hawaiian vetch (Vicia menziesii) is a perennial vine which occurs in forested zones on the island of Hawaii. This species has not been observed in the GRZ, but two occurrences have been reported west of that area boundary in the Ka'u District, approximately $4.8 \mathrm{~km}$ ( 3 miles) west of the Pu'u Makala Natural Area Reserve (TNCH 1989b). This species is therefore considered to have a relatively high potential to occur within the GRZ study area. Three other fern species-Cyanea platyphylla, Scaevola kilauea, and Stenogyne scrophularioides-also occur in the immediate vicinity of the GRZ and may occur within the subzone itself (TNCH 1989b).

\subsubsection{Maui study area}

Four endangered and nine proposed to be listed endangered plant taxa have been reported within a 1-mile radius of the study area on Maui. These species were not observed during the 1993 FWS survey (Evans, Woodside, and Bruegmann 1994)(Table 12). Two of the endangered species (Alectryon macrococcus var. auwahiensis and Lipochaeta kamolensis) and one of the proposed endangered species (Melicope adscendens) are known from only one location each. Lipochaeta kamolensis (Nehe) is restricted to several hundred individuals in one location that is directly in the path of the study area at Kamole Gulch. Although this species was not found during the survey, it is difficult to recognize during the dry season when the survey was conducted. $M$. adscendens (Alani) and A. macrococcus var. auwahiensis (Mahoe) are known from only one population each; these populations fall within the 1-mile radius of the study area. Capparis sandwichiana (Maiapilo) was observed during the survey near the boundary of the 1750 lava flow within the study area between Pu'u Măhoe and Kanahena. The remaining endangered and proposed endangered species are known from the general area but not the study area itself (Table 12).

\section{Animals}

Thirteen species listed as endangered or threatened by the FWS have been documented to occur, or have the potential to occur, in the study area (TNCH 1991, 1993a; Evans, Woodside, and Bruegmann 1994). Table 13 lists the species, and the occurrence and habitat of those species are discussed below. 
Table 12 Endangered and threatened plant taxa that might be found in the study area on Maui

\begin{tabular}{|c|c|c|c|}
\hline Taxon & Common name & Status ${ }^{a}$ & Comments \\
\hline $\begin{array}{l}\text { Alectryon macrococcus var. } \\
\text { auwahiensis }\end{array}$ & Mahoe & $\mathbf{E}$ & \\
\hline Bonamia menziesï & & $\mathbf{C 1}$ & not observed \\
\hline Canavalia pubescens & Jack-bean & $\mathrm{C2}$ & : \\
\hline Capparis sandwichiana & Maiapilo & $\mathbf{C 2}$ & \\
\hline Chamaesyce celastroides var. lachiensis & 'Akoko & $\mathbf{E}$ & Clermontia lindseyana \\
\hline Aha wai & P E & $\begin{array}{l}\text { not } \\
\text { observed }\end{array}$ & $\therefore$ \\
\hline Flueggea neowawraea & Mahamehame & $\mathbf{C 1}$ & not observed \\
\hline Lipochae ta kamolensis & Nehe & $\mathbf{E}$ & only known location \\
\hline Melicope adscendens & Alani & PE & \\
\hline Melicope knudsenii & Alani & $\mathrm{PE}$ & old sighting \\
\hline Melicope mucronulata & Alani & $\mathbf{E}$ & not observed \\
\hline Neraudia sericea & Ma'aloa & $\mathrm{Cl}$ & not observed \\
\hline Nototrichüum humile & Kulưi & $\mathbf{E}$ & \\
\hline Ophioglossum concinnum & Adder's tongue & C1 & $\because \cdots$ \\
\hline $\begin{array}{l}\text { Santalum freycinetianum var. } \\
\text { lanaiense }\end{array}$ & 'Tliahi & $\mathbf{E}$ & \\
\hline Sesbania tomentosa & Ohai & C1 & not observed \\
\hline Zanthaylum hawaiiense & A'e & PE & not observed \\
\hline
\end{tabular}

$\mathrm{E}=$ endangered; $\mathrm{PE}=$ proposed endangered; $C=$ = category 2 candidate (see text for definition).

bld sighting $=$ taxon not seen at that location since 1975.

Source: Evans, Woodside, and Bruegmann 1994. 
Table 13. Endangered or threatened animals in the study area on the islands of Hawaii, Maui, and Oahu

\begin{tabular}{|c|c|}
\hline $\begin{array}{c}\text { Species } \\
\text { Scientific name (common name) } \\
\end{array}$ & Federal status ${ }^{a b}$ \\
\hline \multicolumn{2}{|l|}{ Birds } \\
\hline $\begin{array}{l}\text { Buteo solitarius } \\
\text { (Hawaiian hawk, 'io) }\end{array}$ & E \\
\hline $\begin{array}{l}\text { Hemignathus munroi } \\
\text { (Akiapola'au) }\end{array}$ & $\mathbf{E}$ \\
\hline $\begin{array}{l}\text { Oreomystis mana } \\
\text { (Hawai'i creeper) }\end{array}$ & $\mathbf{E}$ \\
\hline $\begin{array}{l}\text { Psittirostra psittacea } \\
\text { ('O'u) }\end{array}$ & $\mathbf{E}$ \\
\hline $\begin{array}{l}\text { Laxops coccineus coccineus } \\
\text { (Hawai' 'akepa) }\end{array}$ & $\mathbf{E}$ \\
\hline $\begin{array}{l}\text { Nesochen sandvicensis } \\
\text { (Hawaiian goose, Nene) }\end{array}$ & $\mathbf{E}$ \\
\hline $\begin{array}{l}\text { Laxioides bailleui } \\
\text { (Palila) }\end{array}$ & $\mathbf{E}$ \\
\hline $\begin{array}{l}\text { Fulica americana alai } \\
\text { (Hawaiian coot, 'Alae ke'o ke'o) }\end{array}$ & $\mathbf{E}$ \\
\hline $\begin{array}{l}\text { Himantopus mexicanus knudseni } \\
\text { (Hawaiian stilt, Ae'o) }\end{array}$ & $\mathbf{E}$ \\
\hline $\begin{array}{l}\text { Gillinula chloropus sandvicensis } \\
\text { (Hawaiian moorhen, 'Alae 'ula) }\end{array}$ & $\mathbf{E}$ \\
\hline $\begin{array}{l}\text { Anas wyvilliana } \\
\text { (Hawaiian duck, Koloa) }\end{array}$ & $\mathbf{E}$ \\
\hline $\begin{array}{l}\text { Puffinus newelli } \\
\text { (Newell shearwater, 'A'o) }\end{array}$ & $\mathbf{T}$ \\
\hline \multicolumn{2}{|l|}{ Mammals } \\
\hline $\begin{array}{l}\text { Lasiurus cinereus semotus } \\
\text { (Hawaiian hoary bat) }\end{array}$ & $\mathbf{E}$ \\
\hline
\end{tabular}

Refers to federal status (USFWS 1987). State status generally follows federal listings (i.e., a species and that is federally listed as endangered is also considered endangered by the State of Hawai'i).

bKey to federal status (USFWS 1985a, 1987):

$$
\begin{aligned}
& \mathbf{E}=\text { Endangered. } \\
& \mathbf{T}=\text { Threatened. }
\end{aligned}
$$

Source: Evans, Woodside, and Bruegmann 1994; TNCH 1991, 1993. 


\section{Forest birds}

The forest birds of the Hawaiian Islands are a unique biological resource that represent one of the most dramatic examples of adaptive radiation on earth. Hawaiian forest birds are quite sensitive to anthropogenically imposed or facilitated disturbances and predation. Approximately 40 species became extinct between the time of Polynesian colonization of the islands (400 AD.) and Captain Cook's arrival in 1778. Since Western contact, 20 additional species have become extinct, and 31 species are federally listed as threatened or endangered. The study area includes the habitats of seven endangered forest birds. The following discussion on the occurrence and habitats of these species is based on a detailed study of Hawaiian forest birds conducted between 1976 and 1983 (Scott et al. 1986).

The Hawaiian hawk The Hawaiian hawk, Buteo solitarius ('i'), is endemic to the island of Hawaii, where it occurs at elevations below $2591 \mathrm{~m}$ (8500 ft). This hawk has occasionally been observed on Kauai, Maui, and Oahu, but it is known to breed only on the island of Hawaii (FWS 1984). The Hawaiian hawk can utilize a wide range of habitats including forests, grasslands, and agricultural fields (Scott et al. 1986). Its decline is a result of shootings and harassment of nest sites. On the island of Hawaii, it occurs on the slopes of Mauna Loa, on both the windward and Kona coasts, and less commonly on Mauna Ke'a. Many sightings have been made in and near Hawaii Volcanoes National Park, the Pu'u Makaala Forest Reserve, and in the upper Waiakea Forest Reserve. The Puna District reportedly supports a large breeding population (Lamoureux et al. 1985). Recent surveys in the vicinity of the GRZ have estimated that 13-27 Hawaiian hawks inhabit the area (Reynolds et al. 1994b)

The Hawaiian goose. The Hawaiian goose, Nesochen sandvicensis (Nene), is limited to the islands of Hawaii and Maui. It lives on arid lava flows, eating leaves, flowers, and buds of Hypocharis radicata and the fruits of Vaccinium spp., Coprosma emodeoides, and other plants (Scott et al. 1986). The bird may also use open pastures and stock ponds. There are approximately 400 Hawaiian geese in the wild. Recent lava flows in the saddle area between Mauna Kea and Mauna Loa provide habitat for approximately 25 to $50 \%$ of the entire population of the species. Dry subalpine ohia scrub and grassland vegetation types support the highest population densities. The Hawaiian goose usually nests in areas of sparse vegetation, although it has been reported in forested kipukas (Scott et al. 1986).

The Hawaiian goose population is dependent on the release of goslings reared in captivity to sustain population numbers. The inability of the wild populations to perpetuate themselves may be a result of inadequate food quality for goslings, habitat modification, and predation.

Akiapolaau. The Akiapolaau (Hemignathus munroi) is a unique honeycreeper with a stout lower bill and a slender, curved upper bill. Although the Akiapolaau was once widely distributed in the koa-ohia forests and mamane-naio woodlands of Hawaii, it is now rarely found. Deforestation and habitat fragmentation have been major causes for the decline of this species. Maintenance of koa, mamane, and naio in the forests is an important requirement for foraging by Akiapolaau and the species' ultimate survival. 
Currently, the Akiapolaau occurs in four disjunct populations on Hawaii. Two of these populations are on the windward slopes of Mauna Kea and Mauna Loa. Both of these areas are within the vicinity of the study area. The disjunct populations on the slopes of Mauna Kea are separated by a narrow band [ $3 \mathrm{~km}$ (1.9 miles)] of pasture land, demonstrating the dramatic effect of deforestation and fragmentation on this species.

Ou. The Ou (Psittirostra psittacea) are extremely rare. Their occurrence is limited to two populations, one of approximately $\mathbf{4 0 0}$ birds on the island of Hawaii, and another of approximately 6 birds on Kauai (Scott et al. 1986). The birds on the island of Hawaii inhabit the Puna and Hamakua regions. The Ou were once common on the islands of Hawaii, Maui, Molokai, Lanai, Oahu, and Kauai. Their decline is attributed to loss of forest lands, habitat fragmentation, and avian disease (Scott et al. 1986).

They feed principally on fruits. The Ou are most abundant from 1300 to $1500 \mathrm{~m}$ (4300 to $4900 \mathrm{ft}$ ) elevation in mesic and wet ohia forests. The highest concentrations of birds observed during the 1977 forest bird survey (Scott et al. 1986) were in kipukas south of the Saddle Road in the Upper Waiakea Forest Reserve. A 1984 resurvey of these populations showed that they have declined from the reported 1977 levels (Scott et al. 1986).

Palila. The Palila (Laxioides bailleui) occur only on the upper slopes of Mauna Kea. The primary population center recorded during the 1977 forest bird survey were near Pu'u Laau. A secondary population center occurs northeast of the Mauna Kea State Park. The total population size has varied between 1600 and 6400 birds in the past 20 years (Scott et al. 1986). Palila inhabit mamane-naio forests and feed primarily on green pods of the mamane tree. Their distribution is limited by the extent of the mamane-naio forests, and their numbers are greater in forests having relatively dense crown cover, tall trees, and native plant understory (Scott et al. 1986).

Hawaii creeper. The Hawaii creeper (Oreomystis mana) was once a common bird on Hawaii, inhabiting a wide range of habitats in Kona and Hamakua (Scott et al. 1986). The decline of this species has been attributed to avian disease and interspecific competition with the Japanese White-eye. Currently four disjunct populations totaling approximately 12,500 birds exist. The largest population (10,000 birds) occurs in the Hamakua area. The birds inhabit wet montane ohia forests and feed on insects, spiders, and other invertebrates. The birds are most common in koa-ohia forests. The elevational range of the species is 700 to $2200 \mathrm{~m}$ ( 2300 to $7200 \mathrm{ft}$ ), but the highest densities are in undisturbed, wet forests above $1500 \mathrm{~m}$ (4900 ft) (Scott et al. 1986).

Akepa The Akepa (Larops coccineus) historically inhabited the islands of Hawaii, Maui, Oahu, and Kauai, but presently occurs only within limited ranges on the islands of Hawaii, Maui, and Kauai. Approximately 14,000 individuals exists on Hawaii, in three disjunct populations (Scott et al. 1986). Approximately $\mathbf{8 0 0 0}$ birds exist within the Hamakua area, which is within the study area. Akepa are most common above $1500 \mathrm{~m}$ ( $4900 \mathrm{ft}$ ) in mesic and wet forests. The preferred habitat in the Hamakua region is in forests with native understory vegetation. The Akepa feeds on insects, using its unusual bill for foraging leaf buds and terminal leaf clusters. 


\section{Waterbirds}

Unless otherwise referenced, the following information on the status and habitat requirements of Hawaii's five endangered waterbird species is taken from the Hawaiian Waterbirds Recovery Plan (FWS 1985) and a draft revised Hawaiian Waterbirds Recovery Plan (referenced by Evans, Woodside, and Bruegmann 1994).

Hawaiian stilt. The Hawaiian stilt (Himantopous mexicanus laundseni, Ae'o) is a highly gregarious and semicolonial wading bird closely allied with the black-necked stilt of North America. Colonization in Hawaii by stilts probably began with a few migrant individuals. Hawaiian stilts use fresh, brackish, and saltwater habitats. Preferred habitats include early successional marshlands interspersed with areas of mudflat or shallow open water; shallowly flooded [ $<15 \mathrm{~cm}$ (6 in)], low-growing Paspalum sp. or Batis maritima flats; and exposed tidal mudflats. Stilts rarely occur in wetlands above an elevation of $200 \mathrm{~m}$ (656 ft). Feeding habitat consists of shallow water areas. Stilts eat a wide variety of aquatic organisms, including polychaete worms, crustaceans, aquatic insects, and small fish (Shallenberger 1977). Loafing sites include open mudflats, Batis flats, and fresh or brackish water ponds.

Stilts nest on mudflats or adjacent to or on low-relief islands within bodies of fresh, brackish or salt water. They prefer to place their nests on small, bare, or sparsely vegetated islands in shallow ponds with stable water levels but will also use other dry, bare sites near shallow water (Coleman 1981). Stilts may nest and forage in different wetland sites, and the birds will move between these areas daily.

Many factors-including indiscriminate hunting, predation by introduced species, and most importantly, the loss of wetland habitat-contributed to the decline of the Hawaiian stilt. Historic population numbers of Hawaiian stilts are unknown. Munro (1960) suggested that the population had declined to about $\mathbf{2 0 0}$ birds by the early 1940s; however, this may have been an underestimate, since Schwartz and Schwartz (1949) estimated about 1000 birds in the late 1940s. Population counts from 1960 to 1979 fluctuated from a low of 253 in 1960 to a high of 1476 in 1977. Long-term population trends of the Hawaiian stilt indicate that statewide populations have been relatively stable or slightly increasing for the last 20 years (Reed and Oring 1994). Since 1983, statewide surveys have documented 1000 or more stilts in the islands. The majority of Hawaiian stilts are found on the islands of Oahu, Maui, and Kauai Engilis and Pratt (1993) estimate the current statewide population to be between 1200 and 1600 birds.

Hawaiian coot. The Hawaiian coot (Fulica americana alai, 'Alae ke'o ke'o) is a subspecies of the American coot. This subspecies probably originated with a group of migrant coots from continental North America that remained as residents in the islands. Hawaiian coots use fresh and brackish water marshes and ponds where emergent vegetation is interspersed with open water. They are typically found in coastal plain wetlands up to $400 \mathrm{~m}$ (312 ft) in elevation, but they are also known to use upland plunge pools (Kauai) and montane stock ponds (Hawaii) at elevations up to $2000 \mathrm{~m}(6562 \mathrm{ft})$. 
Coots typically forage in water less than $30 \mathrm{~cm}$ (12 in.) deep but can dive in water up to $1.2 \mathrm{~m}$ (4.0 ft) in depth. Hawaiian coots prefer freshwater wetlands for feeding but also feed in brackish waters and rarely in saline waters. Food items include seeds and leaves of aquatic plants, small fish, and invertebrates, including snails, crustaceans, and aquatic and terrestrial insects (Schwartz and Schwartz 1949). Loafing sites include logs and rafts of vegetation, narrow dikes, mud bars, artificial islands, "false nests," and deep, open bodies of water such as reservoirs. Coots prefer areas with a 50:50 mix of open water and emergent vegetation for nesting (Byrd et al. 1985).

Historically, coots occurred on all major Hawaiian islands except Lana'i and Kaho'olawe, which apparently never had suitable waterbird habitat. In the first half of this century, Schwartz and Schwartz (1949) pointed out the decline and potential threat of extinction of the Hawaiian coot. Censuses from the 1950 s to the late 1960 s indicated a population of fewer than 1000 birds. Currently, Hawaiian coots inhabit all main Hawaiian islands except Kaho'olawe. Engilis and Pratt (1993) estimate that coot populations fluctuate between 2000 and 4000 birds, depending on climatic conditions, with Kauai, Oahu, and Maui supporting $80 \%$ of these birds.

Hawaiian moorhen. The Hawaiian moorhen (Gallinula chloropus sandvicensis, 'Alae 'ula) is a nonmigratory, endemic subspecies of the common moorhen of North America (AOU 1983). There are no distinct plumage, soft body coloration, or measurement differences that can be used to distinguish the Hawaiian moorhen from the North American moorhen (Wilson and Evans 1990.) The bird's habitat consists of fresh or slightly brackish water marshes having dense stands of robust, emergent vegetation interspersed with open water; taro patches; lotus fields; vegetated margins of stream and irrigation ditches; reservoirs; and wet pastures. An overall ratio of 50:50 between vegetation and open water is thought to be optimum (Weller and Fredrickson 1973) with a water depth of less than $1 \mathrm{~m}$ ( $3 \mathrm{ft}$ ). Hawaiian moorhens prefer coastal habitats less than $125 \mathrm{~m}$ (410 ft) in elevation and tend to remain close to cover. Nesting, feeding, and loafing sites are generally in the same area.

Because of their secretive nature, Hawaiian moorhens prefer to forage in dense, emergent vegetation. They are opportunistic feeders, and their diet varies with the particular habitat used (Shallenberger 1977). Documented food items include algae, guava seeds, and other plant material and aquatic insects and mollusks (Schwartz and Schwartz 1949; Telfer unpubl data). Hawaiian Moorhens generally nest in areas with standing freshwater, normally less than $60 \mathrm{~cm}$ (24 in.) deep. Nesting occurs year-round, but most activity extends from March through August (Shallenberger 1977).

In 1891, Hawaiian moorhens were common on the main Hawaiian islands except Lanai and Kaho'olawe (Munro 1960). However, by the late 1940s, Schwartz and Schwartz (1949) considered the status of Hawaiian moorhens to be "precarious," especially on Oahu, Maui, and Molokai. Because of its secretive nature, the Hawaiian moorhen is difficult to census. Censuses in the 1950s and 1960s estimated no more than 57 birds. The spread of aquaculture on Kaua'i and Oahu from the late 1970s through the 1980 s added to the available moorhen habitat and probably resulted in an increase in the numbers of these birds. 
Hawaiian moorhens now exist only on Kauai and Oahu. However, because of the inability to adequately survey moorhens, an accurate population estimate cannot be made. Some estimates place the statewide population of moorhens at 750 birds, with approximately 500 birds found on Kauai and about 250 birds found on Oahu. Engilis and Pratt (1993) believe that estimates of the current population size are low because of the number of habitat areas that were missed during statewide surveys.

Hawaiian duck. The Hawaiian duck (Anas wyvilliana, koloa) has been described as either a full species or a subspecies of either the mallard (A. platyrhynchos) or the gray duck (A. superciliosa) several times since it was first described in 1851 (Bostwick 1982). The updated A.O.U. checklist maintains the Hawaiian duck as a full species (AOU 1983). Recent genetic studies indicate that the Hawaiian duck is distinct at the species level and is related to the North American mallard complex (Brown et al. 1993). The Hawaiian duck is a typical dabbling duck similar to the North American mottled duck. Historically, the Hawaiian duck used a variety of natural wetland habitats including freshwater marshes, flooded grasslands, coastal ponds, streams, mountain pools and bogs, and forest swamplands from elevations ranging from sea level up to $3000 \mathrm{~m}$ (9843 ft). Many of these low-elevation wetlands have been completely altered, destroying or severely limiting their value to Hawaiian ducks. Other lowland habitats currently used by Hawaiian ducks include irrigation ditches, flooded fields (taro patches), reservoirs, mouths of larger streams with outlets to the sea, and managed refuge lands.

The majority of Hawaiian ducks are found on Kauai, where they primarily inhabit montane streams. Hawaiian ducks in the Kohala Mountain region of the island of Hawaii use stock ponds, reservoirs, irrigation ditches, and mountain stream habitat (Paton 1981). On Oahu, Hawaiian ducks use the managed impoundments at the James Campbell National Wildlife Refuge, the aquaculture ponds adjacent to the refuge, and various marshes still supporting open-water areas, such as Punaho'olapa, Kawainui, and He'eia.

Like other Hawaiian waterbirds, Hawaiian ducks were historically found on all major Hawaiian Islands except Lanai and Kaho'olawe. There are no estimates of Hawaiian duck populations prior to recent years. Nevertheless, natural wetlands and agricultural wetlands developed by Hawaiians provided extensive waterbird habitat, and it is likely that the Hawaiian duck was once fairly common. The number of Hawaiian ducks declined noticeably early in this century, primarily due to alien predators, hunting, and loss of habitat from changes in agricultural practices and urban development. By 1949, only an estimated 500 ducks remained on Kauai (with unknown numbers on Ni(ihau), and about $\mathbf{3 0}$ ducks remained on Oahu. They were considered only an occasional visitor to the island of Hawaii and were extirpated on Maui and Molokai (Schwartz and Schwartz 1949).

Restoration efforts, including captive breeding and release, between 1958 and 1982 have been somewhat successful, and these ducks are now found on Kauai, Oahu, and Hawaii. The most current estimate of the statewide Hawaiian duck population is 2500 birds, with approximately 2000 birds found on Kauai, 300 birds found on Oahu, and 200 birds found on Hawaii (Engilis and 
Pratt 1993). Hybridization with mallards (especially on Oahu), predation by alien mammals, and habitat loss continue to limit local populations of Hawaiian ducks.

Newell shearwater. The Newell shearwater (Puffinus newelli, 'a'o), has recently been reported to occur in three areas within the vicinity of the GRZ (Reynolds et al. 1994a). During that survey, approximately 260 sitings were made at three locations. Two locations in the vicinity of the GRZ are considered to be colony nesting/breeding sites. Other nesting areas for this endangered bird are known to exist on Kauai and Molokai.

\subsection{Mammals}

Hawaiian hoary bat. The Hawaiian hoary bat (Lasiurus cinereus semotus), a federally listed endangered species, is the only endemic Hawaiian land mammal. This bat is found primarily on the island of Hawaii, where it has been observed from sea level to $4023 \mathrm{~m}(13,200 \mathrm{ft})$ at the Mauna Kea Science Reserve (Berger et al. 1981). It was also observed during a field survey for the Kahaua-Le'a project (unpublished data in MCM Planning provided to DBED in 1989). Hawaiian hoary bats are also frequently observed over Hilo Bay (Van Riper and Van Riper 1982), and they have been sighted along the northwest coast, at Ohaiula Beach in Kawaihae Bay. The bat is the only native mammal known to occur in the study area. It was observed once during the biological survey of Volcano National Park, which is adjacent to the study area (unpublished data by MCM Planning provided to DBED in 1989). The bat has been observed in several locations in the study area (Reynolds et al. 1994c).

\section{Protected Ecological Areas}

Sensitive community types and protected ecological areas in the vicinity of the study areas are described in this section.

\subsubsection{Sensitive community types}

Ecologically sensitive areas include those areas that are protected or regulated by the state of Hawaii or federal agencies, are listed by the Nature Conservancy as rare habitats or communities, or are areas with a concentration of rare species. The following discussion of ecologically sensitive areas within the study area (except wetlands, which have been discussed in Sect. 2.4) is based on data from the HHP (TNCH 1993). This information should be augmented by site-specific surveys prior to any detailed site development planning.

There are no areas that have been recognized or designated as ecologically sensitive by the HPP or the Department of Land and Natural in the vicinity of the GRZ. Along the study area corridor on the island of Hawaii five community types have been recognized by the Nature Conservancy as being ecologically sensitive, and one area in the vicinity of Pu'u Huluhulu merits special consideration. 
The Deschampsia nubigena subalpine mesic grassland. The Deschampsia nubigena subalpine mesic grassland is a tussock-forming community dominated by the endemic grass Deschampsia nubigena. This habitat is found in at least five locations within the study area in the Humuula saddle area. These habitats occur generally within the dry and moist native shrub-ohia vegetation types (units 9 and 50) that were delineated by the FWS (Jacobi 1989). These sites consist of scattered, open canopy ohia with dry mixed grasses and native shrubs (Jacobi 1990). This grassland type provides forage for the Hawaiian goose. Threats to this grassland community include feral pigs and invasion of alien plants (TNCH 1989c).

Koa/ohia mixed-montane mesic forest. The koa/ohia mixed-montane mesic forest is a 180-ha (450-acre) tract occurring on south- to southeast-facing slopes of Mauna Kea. Koa is the dominant canopy species; ohia and other native trees may exist in the subcanopy. The understory consists of native shrubs and alien grasses (TNCH 1993). This community contains the rare Huperzia mannï, Cyanea kunthiana, Melicope Hawaïensis, and Palmeria dolei (TNCH 1993). Threats to this community including browsing by feral pigs, cattle, and goats and fire.

Mamane/naio subalpine dry forest. The mamane/naio subalpine dry forest consists of opento closed-canopy naio and mamane in the subcanopy. The understory consists of mixed grasses and native shrubs. The topography is gentle to steep south-facing slopes. Although historically, this forest type was of much larger extent, most of the former range has been cleared for pasture land. Accordingly, the occurrence of this forest in the Humuula saddle is an important occurrence of this type. This forest provides critical habitat for the Palila, and habitat for the Hawaii creeper, Akiapola'au, and Akepa, each federally listed endangered species. Threats to this forest include grazing by feral ungulates, invasion by alien plant species, and military maneuvers.

Hard-stemmed lovegrass subalpine dry grassland. The hard-stemmed lovegrass community is unique to the Humuula saddle area; it consists of two native grasses-hard-stemmed lovegrass (Eragrostis atropioides) and Deschampsia -and a Chenopodium shrub overstory. The grassland occurs on gentle to steep slopes at all aspects on Mauna Kea in the 5520- to 7160-ft elevation zone. This community may contain the rare plant Haplostachys haplostacha, and it provides habitat for the Hawaiian hawk and goose (TNCH 1993). Threats to this community type include invasion by alien species and military maneuvers.

Aweoweo subalpine dry shrubland. The Aweoweo subalpine dry shrubland consists of open to closed canopy of Chenopodium oahuense, 0.75 to $2.5 \mathrm{~m}$ ( 2.5 to $8.2 \mathrm{ft}$ ) tall, with an understory of native and alien shrubs and grasses. This shrubland occurs primarily on west-facing slopes and flat areas on alluvial soils (TNCH 1993).

Pu'u Huluhulu Several rare birds and plants inhabit Pu'u Huluhulu, in the Humuula saddle. Those species include federally listed Hawaiian goose and Palia, and the rare plants Stenogyne microphylla, Sicyos macrophyllus, Solanum incompletum, and Clemontia pynilaria (TNCH 1993). 


\subsubsection{Protected ecological areas}

The study area is in the vicinity of two natural area reserves (NARs), one wildlife sanctuary, and one state recreation area on the island of Hawaii (Fig. 7), and one NAR on Maui (Fig. 8). The NARs were established in 1970 by the state of Hawaii to preserve representative examples of the islands' biological and geological features. The following is a brief description of each of the protected zones that are in the vicinity of the study area.

Kahaua-Le'a NAR. The Kahaua-Le'a NAR, located to the northwest of the GRZ, contains one of the few examples of native, lowland rain forests. This NAR contains the ohia/hapu'u (Cibotium glaucum) lowland wet rain forest, which is considered rare by the Nature Conservancy. This community type is similar to the ohia/fem forest delineated within the GRZ. Palai-la'au (Adenophorus periens), a federally listed rare plant, may occur within the ohia forests in this NAR (TNCH 1987).

Pu'u Maka'ala NAR. The Pu'u Maka'ala NAR is a 4900-ha (12,000-acre) reserve on the northeast flank of Mauna Loa. This NAR contains two rare vegetation community types as designated by the HPP, the koa-ohia montane wet forest and the 'uki (Carex allegata) montane wet grassland. The koa-ohia montane forest provides habitat for native forest birds, and the 'uki grassland is considered a wetland community type. This NAR is functionally a part of the 'Ola'a rain forest within the Hawaii Volcano National Park (TNCH 1987).

Waiakea 1942 Lava Flow NAR. The Waiakea 1942 Lava Flow NAR is a 260-ha (640. acre) tract representative of successional development on recent lava flows. The current vegetation consists of early successional ohia forests (TNCH 1987).

Mauna Kea Ice Age NAR The Mauna Kea Ice Age NAR is located on the south flank of Mauna Kea. This area is a unique example of a sparsely vegetated alpine desert. Important community types include the Racomitrium lanuginosum alpine dry herbland, Hawaiian alpine aeolian desert, lichen alpine dry herblands, and the Hawaiian glacial tropical lake (TNCH 1987).

Pu'u o'Umi NAR. The Pu'u o'Umi NAR, in the Kohal mountains, contains seven rare community types (TNCH 1987). They include wetlands (ohia/Sphagnum spp. mixed montane bog, 'uki montane wet grassland, and perennial streams) and communities that may provide habitat for rare plants and animals (Ohia montane wet shrubland, mixed fern/ape'ape (Funnera petaloidea) montane wet cliffs, ohaifolapa (Cheirodendron trigynum) montane wet forest, and ohia/Sphagnum spp. montane wet forest).

Kanaio NAR. The Kanaio NAR on Maui was created to protect the lower dryland forest vegetation of East Maui (TNCH 1987).

Kipuka 'Ainahou State Nene Sanctuary. The Kipuka 'Ainahou State Nene Sanctuary, located adjacent to the Saddle Road in the Humuula saddle, is a sanctuary for the federally listed 


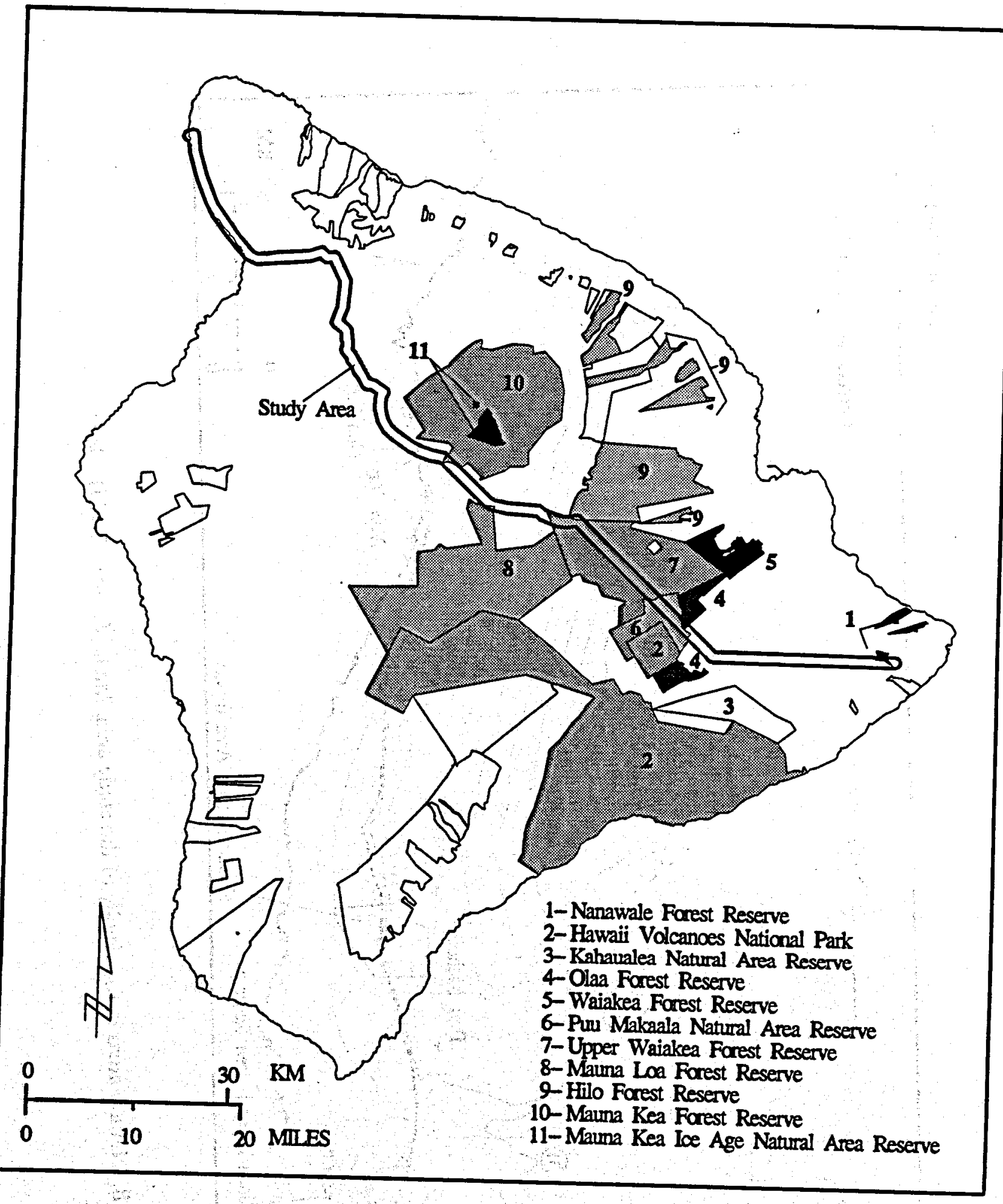
Fig. 7. Natural areas in the vicinity of the study area on Hawaii Source: Redrawn from
unpublished data by MCM Planning provided to DBED in 1989. 
ORNL-DWG 95-5970

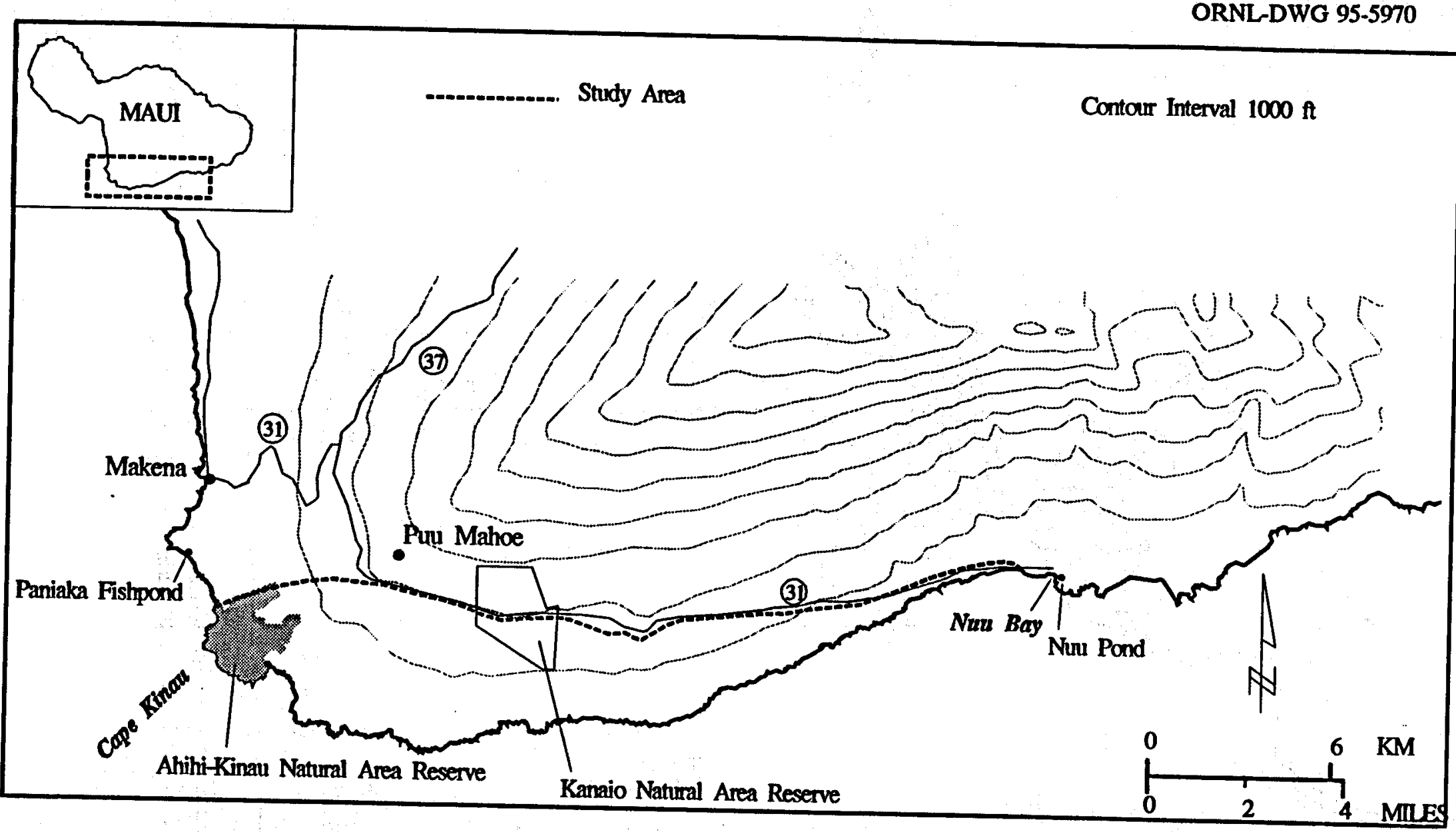

Fig. 8. Natural areas in the vicinity of the study area, Maui. Source: TNCH 1989a. 
Hawaiian goose (Nesochen sandvicensis) (TNCH 1987). No entry is permitted in this sanctuary from November 1 through February 28 of each year.

\section{AQUATIC ECOLOGY}

\subsection{GEOTHERMAL RESOURCE ZONES}

There are no perennial streams that support aquatic life within the Kilauea East Rift Zone (KERZ) (Fig. 9). There are, however, a few ephemeral or intermittent streams in the vicinity of the KERZ that result from the high annual rainfall [2.4-3.7 m (8-12 ft)] (Fig. 9). Because of the high permeability of the Kilauea lavas underlying the KERZ, most of the rainfall infiltrates and recharges the basal freshwater system in and adjacent to the zone rather than occurring as surface runoff (Staub 1994, Ingebritsen and Scholl 1993, and Takasaki 1993 as referenced in Sorey and Colvard 1994). Sheet flow, which has been observed in the Puna area (Brock 1993), may occur in the upper, wetter subzones in response to sustained rainfall. These flows, however, cannot sustain surface water bodies or aquatic communities. The Kopoho subzone receives less rainfall than the upper two subzones and provides even less potential for an ephemeral aquatic fauna.

Because of the absence of permanent streams, suitable habitat for most aquatic organisms is lacking and, therefore, aquatic fauna in the KERZ is depauperate. The only aquatic organisms found in the ephemeral streams are those species that can tolerate dry periods or that can survive in a limited number of pools or bogs occurring over nonporous lava (pahoehoe). The extent of these pools and the associated fauna is unknown. As noted above, the porous nature of the lavas in the KERZ facilitates infiltration (rather than surface water retention) and runoff and results in a lack of water available to supply streams and pools. Thus, species such as damselflies that are typically aquatic have evolved the ability to utilize standing waters in the axials of vegetation to survive their aquatic immature stages and to reproduce.

Anchialine pools and freshwater seeps which support a unique assemblage of euryhaline biota occur along the coast adjacent to the KERZ (Fig. 10). Anchialine pools, first designated as such by Holthuis (1973), occur in natural depressions, fissures, quarries, and craters along the coast in areas where the groundwater table is at the land surface, either in porous lavas or in lava tubes. These pools do not have surface connections to the ocean although they may exhibit tidal fluctuations as a result of water flowing through interconnected subterranean cracks (Maciolek 1983). Waters in anchialine pools range from freshwater to highly saline, depending upon the location of the individual pools and the contribution of freshwater and ocean waters to the total composition of water in the pools. Salinity in individual ponds may vary from freshwater at the pool surface to saline at warmer depths (Maciolek 1983). Anchialine pools may have elevated temperatures [29-38 $\mathrm{C}\left(84-100^{\circ} \mathrm{F}\right)$ ], which indicate the presence of heated groundwater (Fisher, Davis, and Sousa 1966; Sorey and Colvard 1994), although most exhibit temperatures within the 
ORNL-DWG 95-5971

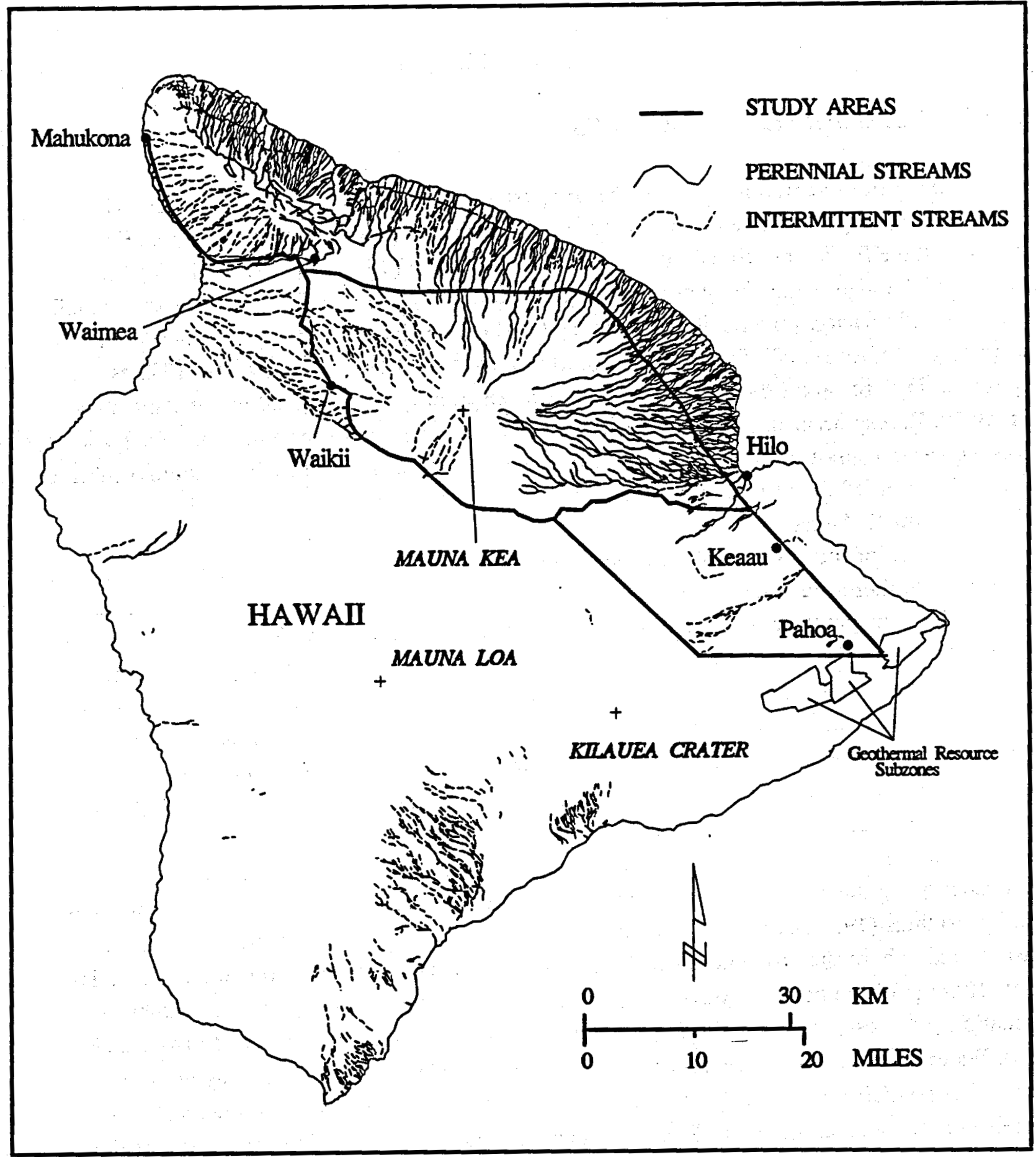

Fig. 9. Perennial and ephemeral streams on the island of Hawaii. Figure shows streams in relation to the resource subzones. Source: TNCH $1989 \mathrm{~b}$. 


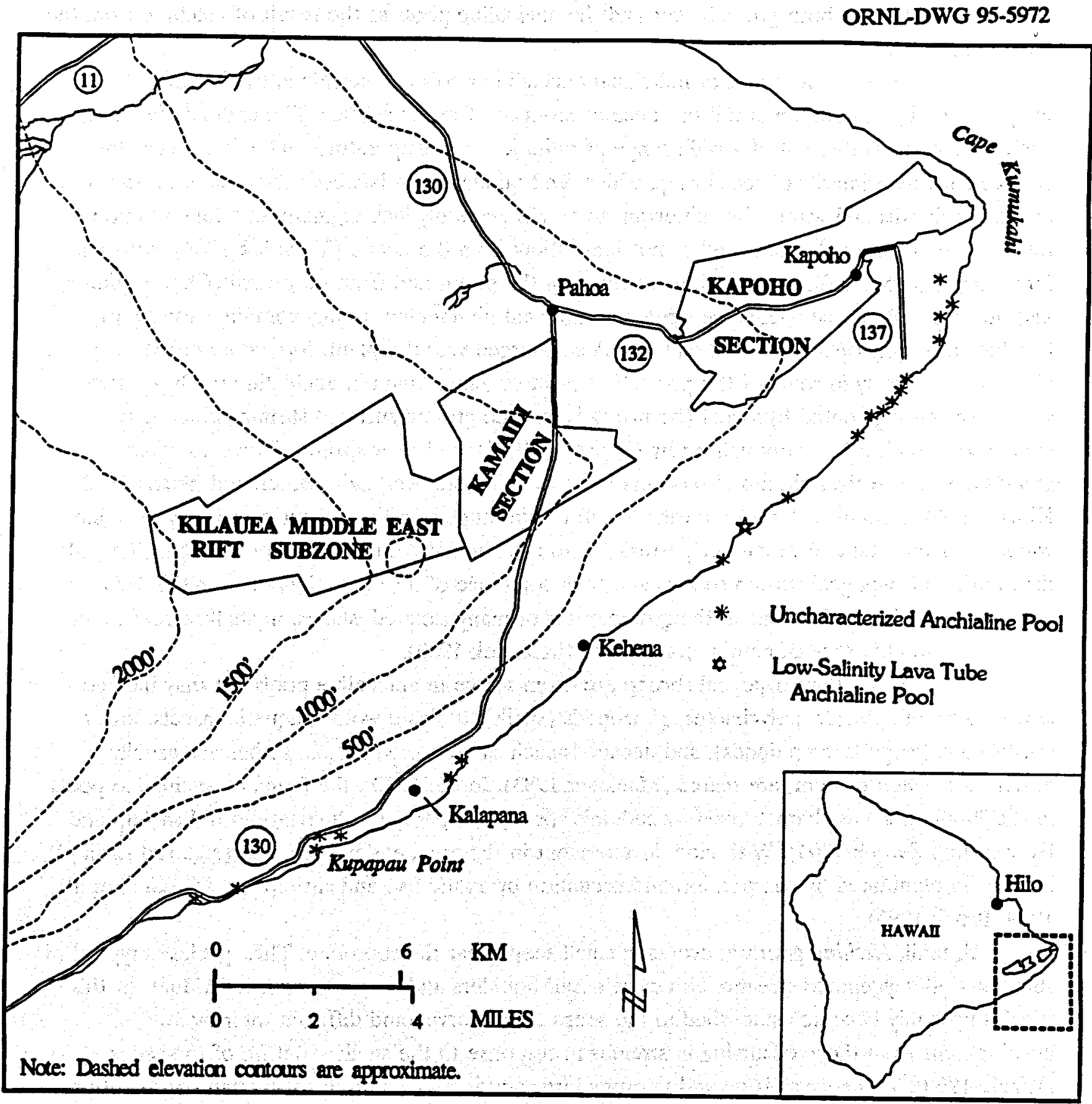

Fig. 10. Location of anchialine pools near the Kilauea east rift subzones. Source: TNCH $1989 \mathrm{~b}$. 
$24-30^{\circ} \mathrm{C}\left(75-86^{\circ} \mathrm{F}\right)$ range (Maciolek 1983). Biota in these pools may occur at depths ranging from shallow to more than $12 \mathrm{~m}$ (39 ft) deep (Maciolek 1983).

The levels of nutrients (e.g., nitrates and phosphates) in the anchialine pools can be very high as the result of leaching from the relatively young lava of the island of Hawaii. Arsenic is also naturally high in both groundwater and the anchialine pools as the result of leaching from the lava (Brock 1993).

The species composition of individual anchialine pools is determined by salinity, temperature, light, depth, and the presence or absence of exotic species. The endemic fauna of anchialine pools is tolerant of a wide range of salinities and temperatures. The fauna near the surface consists primarily of red shrimp, which feed on algae and bacteria; those species occurring at greater depths and within the subterranean cracks generally lack pigment and depend upon nutrient fallout from above as well as nutrient inflow from the ocean (Maciolek 1983). Nutrient input may also occur from vegetation surrounding the ponds and from waterfowl (Chai, Cuddihy, and Stone 1989). Those anchialine pools that are well illuminated usually contain a variety of benthic algae, phytoplankton, and diatoms. A submerged vascular plant, Ruppia maritima, may also grow profusely in some of the pools. The most common fauna in anchialine pools are five species of red pigmented hypogeal (occurring below the ground surface) shrimp, which may coexist with each other, although rarely (Maciolek 1983), and river shrimp, Macrobrachium grandimanus. The river shrimp also occurs in brackish coastal wetlands (Brock and Norris 1988; Kinzie 1990). Hypogeal shrimp are tolerant of a wide range of salinities but occur only in saline waters derived totally or in part by perfusion into rock interstices from the open ocean. The wide distribution of hypogeal shrimp species and their tolerance of a wide variety of salinities indicate that these species could occur in the groundwater of many isolated islands, in shallow reefs, and possibly in suitable rock of continental shelves (Maciolek 1983).

Fauna other than hypogeal shrimp are often scarce in anchialine pools but may include assemblages of sponges, polychaetes, gastropods (snails), tunicate worms, aquatic insects, lower crustaceans (isopods, amphipods), and decapods such as Palaemon debilis. Fishes are usually absent and, when present, are scarce (Maciolek 1983). In the 1970s, the fauna of anchialine pools in the Puna area was characterized by endemic species, primarily the halocaridin red shrimp and river shrimp (Brock 1993). With land development in the area, endemic species (e.g., red shrimp) have been eliminated by competition and predation by exotic fish and shrimp species (Chai et al. 1989; Brock 1993).

A snail, Neritina granosa, occurs in small seeps near the shoreline. This species is typical of shallow, well-oxygenated streams with clear basalt boulders and coarse gravel. Individuals of this species probably become established in the seeps as postlarvae and differ in their overall development from those occurring in streams in response to the shallow nature of the seeps (Kinzie 1990). This species is preyed upon by birds and is also gathered for human consumption. 


\subsection{OTHER STUDY AREAS}

The study area corridor on the island of Hawaii begins at the KERZ and extends across the saddle of the island between Mauna Loa and Mauna Kea to the northwestern end of the island near Makukona Harbor. There are no perennial streams that support aquatic life in this area (Fig. 9). However, a limited number of ephemeral or intermittent streams that result from rainfall are present, particularly in the northwestern third of the study area. Because of the high permeability of the lavas underlying this study area, most of the rainfall infiltrates and recharges groundwater rather than contributing to surface runoff.

The absence of permanent streams results in a lack of suitable habitat for most aquatic organisms and a depauperate aquatic fauna. The only aquatic organisms that would be found in the intermittent streams in this study area are those that can tolerate extended dry periods or that could survive in a very limited number of pools. As noted above, the lack of rainfall and the porous nature of the underlying lavas in the area result in infiltration rather than surface water retention and runoff and, consequently, there is a lack of water available to supply streams and pools and to support aquatic life.

The portion of the study area from the KERZ to Hilo includes several intermittent streams and one permanent stream. Between Hilo and the saddle are several intermittent streams and one permanent stream.

Areas along the northeastern coast of Hawaii have an extensive array of both permanent and intermittent streams. These areas include the upper to middle reaches of most streams. There are no specific studies of all streams along this coast; however, extensive studies of endemic and indigenous fish species in the Hawaiian Islands by Kenzie (1990) are applicable to these streams. The composition of the fish communities in these streams depends upon the habitats available within the individual streams (e.g., hard substrate, rocks and boulders, or soft bottoms) as well as upon the amount of disturbance within the watershed and, consequently, the amount of sedimentation that has occurred in the streams. The lower reaches of the streams, particularly the areas closest to the coast, would be characterized by endemic and indigenous species and other. species that can inhabit both fresh and salt water that may or may not be endemic to the Hawaiian Islands (Kenzie 1990; Devick 1991). Eleotris sandwicensis ('o'opu 'akupa 'oau), a goby, is restricted to estuaries and lower stream reaches, although it may occur farther inland in lowgradient streams. This habitat restriction occurs because this species lacks the paired pelvic fins of the true gobies and cannot climb the waterfalls that are characteristic of many streams along this coast (Kinzie 1990). Stenogobius genivittatus ('o'opu naniha), a true goby, is the only nonendemic native Hawaiian stream fish. This species occurs in estuarine habitats or just upstream from estuarine conditions (Kinzie 1990). Awaous stamineus ('o'opu nakea), the largest Hawaiian stream goby, generally occurs in lower stream reaches in deeper, slower-moving waters that are characterized by fine sediments or gravel (Kinzie 1988). This species is fished for home consumption. Sicyopterus stimpsoni ('o'opu nopili), a relatively small endemic goby, is restricted to relatively undisturbed streams with good water quality and high rates of discharge. This species is 
not found in streams where the habitat has been extensively altered, where exotics are abundant, or where development in the watershed has increased siltation in its habitat (Kinzie 1990). Lentipes concolor ('o'opu 'alamo'o), the rarest of the Hawaiian gobies, is found on the windward sides of all the major Hawaiian Islands except Oahu (Kinzie 1990). This species is a good climber and is generally found in relatively undisturbed streams in remote areas at middle to high elevations. The species was listed as threatened by the American Fisheries Society in 1979 (Deacon et al. 1979) and as a category 1 candidate endangered species in 1985 (Dodd et al. 1985). (A category 1 candidate is one for which substantial information exists that would warrant listing the species.) It currently remains classified as a category 1 species (Roberts 1994).

The endemic crustacean Atyoida bisulcata is found in the upper reaches of nearly every perennial stream in Hawaii (Couret 1976) in habitats ranging from quiet pools to turbulent pools under waterfalls. The species is typically found in swiftly flowing streams (Kinzie 1990).

Macrobrachium grandimanus, also a crustacean, is found primarily in brackish coastal wetlands and in anchialine pools, although it may be common in estuaries. The introduced $M$. lar is widespread in most natural streams, and $M$. rosenbergï occurs in estuaries. Maciolek (1972 as cited by Kinzie 1990) suggested that $M$. lar might be responsible for the diminished numbers of $M$. grandimanus in some streams, although this has not been verified. The mollusk Neritina granosa is the only fully neritid freshwater species in Hawaii. It is generally restricted to the lower and middle reaches of perennial streams. The species prefers shallow, well-oxygenated streams with clean basalt boulders and coarse gravel. Those streams with high flows have populations of this species at higher elevations than smaller streams with low flows. The other three endemic mollusk species$N$. vespertina, Clithon cariosus, and $C$. neglectus-are found in estuaries and lower stream reaches on all the Hawaiian Islands. Little is known about their biology.

\subsection{SOUTH MAUI AND OAHU STUDY AREAS}

The south Maui study area is located on the dry side of the island. There are no perennial streams to support aquatic life in this area (Fig. 11). A limited number of ephemeral or intermittent streams occur, however, particularly in the eastern third of the area. Because of the high permeability of the lavas underlying the area, most of the rainfall infiltrates and recharges groundwater beneath Maui rather than occurring as surface runoff.

The absence of permanent streams results in a lack of suitable habitat for most aquatic organisms and a depauperate aquatic fauna. The only aquatic organisms that would be found in the ephemeral streams in the south Maui study area are those that can tolerate dry periods or that could survive in a very limited number of pools. As noted above, the lack of rainfall and the porous nature of the underlying lavas in the area result in infiltration rather than surface water retention and runoff and, consequently, in a lack of water available to supply streams and pools.

Anchialine pools on the island of Maui are present in the study area on the western portion of the southern coast (Fig. 11). The Paniaka fishpond is located adjacent to Big Beach just south of Makena. This shallow fishpond is brackish and has sparse emergent vegetation 
ORNL-DWG 95-5973

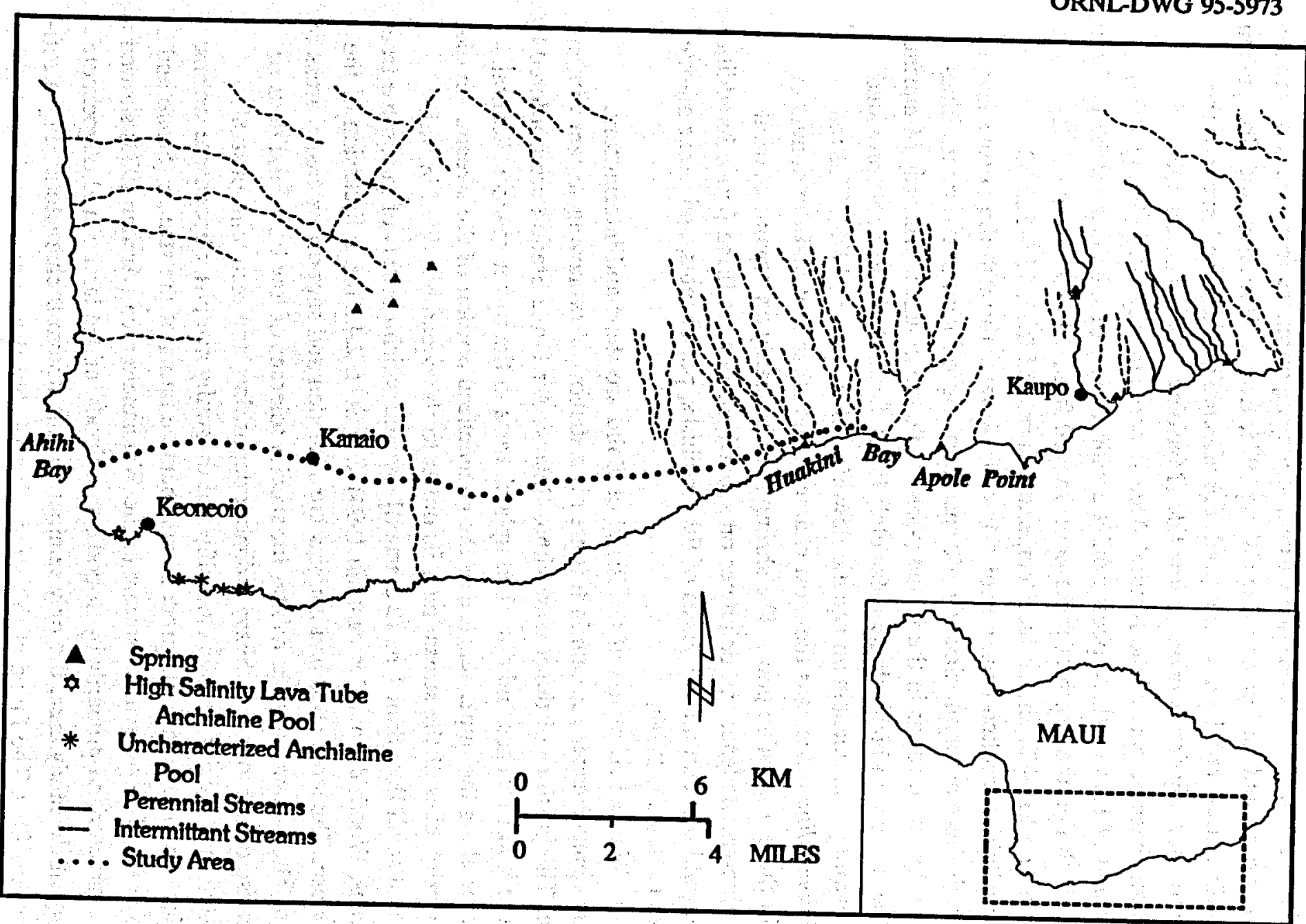

Fig. 11. Location of streams on the island of Maui with respect to the study area. Source: TNCH 1989b. 
growing both within and along the margins. The fishpond is used for feeding by Hawaiian stilts and golden plover (Evans, Woodside, and Bruegmann 1994), as discussed in Sect. 2.4.2. The anchialine ponds within the Ahihi-Kina'u Natural Area Reserve (NAR) are known for their high diversity of rare Hawaiian shrimps and a unique lava tube community that provides habitat for native Hawaiian cave animals. The anchialine pools occur along the Cape Kina'u peninsula seaward to the Makena-Keone'o'io Government Road, at varying distances from the sea between Nuku'ele Point on the cape and La Perouse Bay (Wong 1975; Evans, Woodside, and Bruegmann 1994). The water surface area and depth of the pools are affected by tides, and many of the shallower pools are temporarily drawn down at low tide (Maciolek 1986). These pools and adjoining marine waters became part of the Natural Area Reserve in July 1973 (Wong 1975). Like pools on the island of Hawaii, these pools exhibit a wide variety of salinities and biota. Wong (1975) found that at high tide the depth of these pools ranged from 0.1-3.0 $\mathrm{m}(0.3-9.8 \mathrm{ft})$, salinities ranged from 11.5 to $34 \%$, and surface temperatures ranged from $17.5-30.5^{\circ} \mathrm{C}$ $\left(64-87^{\circ} \mathrm{F}\right)$. The low salinities resulted from percolation of freshwater through the porous lava to groundwater. Although there are approximately 140 species of algae found in the pools, bluegreen algae were the dominant forms in the inland pools, while green algae, primarily of marine origin, dominated the pools with high salinity (Maciolek 1986). Several of the pools provided habitat for Ruppia maritima, an uncommon aquatic flowering plant (Wong 1975). The red caridean shrimp, Halocaridina rubra, was the most characteristic inhabitant and the dominant primary consumer in these anchialine pools. The shrimp feed primarily on organic detrital materials, diatoms, blue-green algae, and epiphytes on submerged flora in these pools. In addition to the shrimp, some pools contain a few species of fish, mollusks, polychaetes, and other marinerelated invertebrates (Maciolek 1986).

Streams in the Waimanalo region of the island of Oahu are short and intermittent. Waimanalo, the only semipermanent stream in this area is a shallow, slow-moving stream with an extended floodplain. The portions of the stream within Bellows Air Force Station are bordered by mangrove trees in the lower reaches and disturbed upland areas in the upper reaches. Several shallow mudflats occur along the upper reaches of the channelized portion of the stream. An old oxbow along the lower reaches of the stream near its outlet to the ocean has filled in with sediment and formed a small [less than 1 ha (2.5 acres)] wetland which consists of mangrove trees and a Batis flat (Evans, Woodside, and Bruegmann 1994). See Sect. 2.4 .2 for a discussion of the wetland area and its use. The streambed and margins are silt-laden and support extensive areas of emergent vegetation. The stream provides habitat for species tolerant of low-flow conditions or standing water. Because of the low flow, heavy sediment deposition, and resultant, unstable substrate, sediment-tolerant species such as damselfly and dragonfly nymphs, oligochaete worms, shore flies, crane flies, and midges are the predominant benthic fauna of the stream (Stone and Stone 1989). A study of a higher-elevation stream in the Waimanalo area (Archer 1983) showed a depauperate fauna characterized primarily by isopods, amphipods, midge larvae, and oligochaete worms. In the vicinity of the study area, the only semipermanent stream is characterized by a softbottom substrate and low flow. The fauna of this stream is probably also composed of damselflies, 
dragonflies, mosquitoes, shoreflies, and a limited number of other species tolerant of a relatively uniform substrate.

\section{MARINE ECOLOGY}

This section addresses the marine environment from Makaohule Point, Hawaii, to the south coast of Maui between Apole Point and Huakini Bay, a distance of approximately $68 \mathrm{~km}$ (42 miles) across the Alenuihaha Channel; and from Kanahena, Maui, to Bellows Air Force Base near Waimanalo, Oahu, a distance of approximately $155 \mathrm{~km}$ ( 96 miles).

Most of this study area is characterized by hard substrates (Campbell 1983; Krasnick and Mansur 1987; Makai Ocean Engineering et al. 1990; Chave and Jones 1991). However, softsediment habitats (coarse sand or finer) occur in a variety of places within the study area, including the bottom of the Alenuihaha Channel at depths of 1200-1900 m (4000-6000 ft) (coarse sand substrate), near the shore in Ahihi Bay (sand substrate), Kalohi Channel at depths of roughly 70-500 m (230-1640 ft) (sand, muddy sand, and muddy clay substrate), Penguin Bank at depths of 40-200 m (130-650 ft) (primarily carbonate sand substrate), the 70-m- (2300 ft) deep floor of the Kaiwi Channel (sand substrate), and the intertidal and shallow subtidal of Waimanalo Bay (sand substrate) (Campbell 1983, Krasnick and Mansur 1987; Agegian and Mackenzie 1990; Makai Ocean Engineering et al. 1990; Balder 1992). By soft-bottom habitat standards, all of these areas are characterized by relatively high physical energy due to current and/or wave energy. Thus, sediment erosion and redeposition are likely to be common.

\subsection{COASTAL ZONE COMMUNITY}

No detailed studies of soft-sediment communities in the study area have been published. However, some generalizations about the community structure at these sites can be made based on studies of the benthos of Hawaii and other tropical and deep-sea environments.

All shallow, soft-sediment sites [intertidal to 200-m (650-ft) depths] harbor complex assemblages of microorganisms, meiofauna, macrofauna, and megafauna, with community structure varying with water depth, sediment type, and physical energy (e.g., Alongi 1990; Gage and Tyler 1991). The macrobiota of intertidal sands is generally dominated by deposit-feeding and suspension-feeding crustaceans and bivalves (e.g., Wenner, Ricard, and Dugan 1987; Alongi 1989a,b, 1990; C. Smith, personal observations). At shelf depths [0-200 m (0-600 ft)] macrofaunal communities include deposit- and suspension-feeding polychaetes, crustaceans, bivalves, and echinoderms (e.g., ophiuroids and holothuroids) as well as calcareous algae, benthic foraminifera, and bryozoans (Agegian et al. 1987; Alongi 1990; C. Smith, personal observations). Community abundance and biomass increase with depth from intertidal sands to shallow subtidal depths, and then decrease as depth increases (Alongi 1990; Gage and Tyler 1991). Because these assemblages 
occur in relatively high-energy settings, the fauna is expected to be relatively tolerant of currents and mobile sediments.

Tropical shallow-water benthos frequently are subjected to natural environmental stress resulting from heavy rainfall and terrestrial runoff; thus, the benthos in these areas, especially near stream outlets, are often tolerant of variable salinity and turbidity (Alongi 1989a,b, 1990). Because of high seawater temperatures, the metabolic growth and production rates of tropical benthos typically are high relative to their temperate counterparts (Hatcher, Johannes, and Robertson 1989; Alongi 1990). (These increased rates occur in spite of partial temperature compensation in tropical benthos.) Finally, tropical marine organisms often exhibit lower tolerance of thermal stress than their temperate counterparts because ambient tropical temperatures typically are relatively close to [i.e., within $5-15^{\circ} \mathrm{C}\left(41-59^{\circ} \mathrm{F}\right)$ ] the upper temperature limits of resident species (Hatcher, Johannes, and Robertson 1989, Alongi 1990).

Commercially or recreationally exploited species living or feeding in these shallow, softbottom habitats include inshore bottom fishes such as goatfishes, bonefish, and threadfins, as well as a variety of deep bottomfishes. These fish species are widespread in soft-bottom habitats throughout the marine environment of Hawaii.

Along the north and western slopes of Kohala from Kawaihae to Pololu Point (the vicinity of the study area on the island of Hawaii), sea cliffs of moderate height are common. Bedrock is exposed along the entire section of this coastline. Mahukona is a harbor with a small boat launching facility. The harbor, which was originally dredged and modified for shipping (Clark 1985), operated as a major shipping port for the Kohala Sugar Company beginning in 1860s. The port was abandoned after the tsunami of 1946 destroyed sections of the railroad used to connect the cane fields with the shipping port. Numerous old piers along the shoreline and submerged artifacts such as cables, anchors, and railroad wheels testify to the earlier importance of this harbor.

A recent baseline survey of marine biota and water quality conducted in the waters off Mahukona identified four major biological zones adjacent to the shoreline. These are defined as "(1) shallow high wave energy zone adjacent to the shoreline, (2) high coral cover at greater depths seaward of the high wave energy zone; (3) deep low coral cover; and (4) sand" (unpublished data by PBR provided to Chalon International of Hawaii in 1990). The first two zones parallel the shoreline for several kilometers, with a sand zone located immediately offshore of the Mahukona harbor.

Surveys of marine invertebrates and fishes of the shoreline and subtidal zone along the west coast of Hawaii (Brock and Brock 1974) included an intertidal collection station at Mahukona. Those invertebrate species recorded at this site were polychaetes, bristle worms, (Protula atypha, Spirorbis marioni, Pileolaria koehleri, Janua pagenstecheri), a crayfish, Grapsus ("ama"); and a limpet, Celana sandvicensis ("opihi"). A complete list of fauna from the intertidal and subtidal zones of the Kona coast of Hawaii is presented in Brock and Brock (1974) and Kay et al. (1977). 
A diverse assemblage of fishes was observed in the high coral cover zone and the shallow high-energy zone (Brock 1990). A list of fish and invertebrates observed during the marine survey is included in Appendix $\mathbf{A}$. The presence of several species of fish that are highly regarded by recreational fishers [e.g., uku (Aprion virescens), mu (Monotaxis grandoculis), moano kea (Parupeneus cyclostomus), and omilu (Caranx melanpygus)] suggests that the fishing pressure at this site is less than that at other west Hawaii sites (unpublished data by PBR provided to Chalon International of Hawaii in 1990).

Along the coast between Apole Point and Huakini Bay on the island of Maui, no reef is present. However, isolated coral heads are reported as moderately abundant (unpublished data from Moberly 1965). The west end of Huakini Bay is reportedly characterized by a sand beach. However, during reconnaissance of Huakini Bay, only isolated dune sands on the upper beach were found along the bay. The beach is characterized as a boulder beach with a steep foreslope-a product of large waves which frequently strike the beach. The site is typical of boulder beaches along the southern coast of Maui.

In the section of coast between La Perouse Bay and Ahihi Bay, there are sporadic sand pocket beaches. The bay at $\mathrm{La}$ Perouse is characterized as a cobble beach with a sand beach at its northwestern end. The nearshore waters are characterized by a mixture of rocky and coral patches; the greatest coral growth occurs at depths between 6 and $9 \mathrm{~m}$ ( 20 and $30 \mathrm{ft}$ )(unpublished data from Moberly 1965).

Waimanalo Beach is the longest continuous beach on Oahu. The sand at Waimanalo Beach is characterized as coarse to medium-grained, well-sorted to poorly sorted. The largest component of the calcareous sand is derived from shells of marine rhizopods. Offshore areas contain large patches of sandy bottom. The offshore reef area is generally low in relief and irregular in shape; a broad sand-bottom channel crosses the northern part of the reef. $A$ topographic profile across the beach and nearshore coastal zone is presented in Fig. 12 (Moberly 1963).

Bellows Air Force Base Beach is heavily used by beachgoers and swimmers on weekends (access is restricted during the week for military activities). Recreational fishing, which includes the use of spears and nets, harvests reef fishes from the offshore waters.

\section{REEF COMMUNITY}

Coral reefs are unique ecosystems that support a diverse marine community. These sensitive ecosystems can be influenced by a variety of perturbations of both terrestrial and marine origin. Grigg (1983) determined that reef composition is remarkably consistent throughout the state of Hawaii. Reefs generally occur at depths ranging from a meter to as much as $\mathbf{2 0 ~ m}$ (3-60 ft), with the most vigorous growth between 2 and $10 \mathrm{~m}$ (6 to $30 \mathrm{ft}$ ) (Maragos 1977). Hawaiian coral fauna is, however, impoverished relative to other subtropical localities with fewer than 50 reef-building species present in Hawaii. The most significant factor determining the structure of the reef community is physical disturbance such as wave stress (Dollar 1982). The 


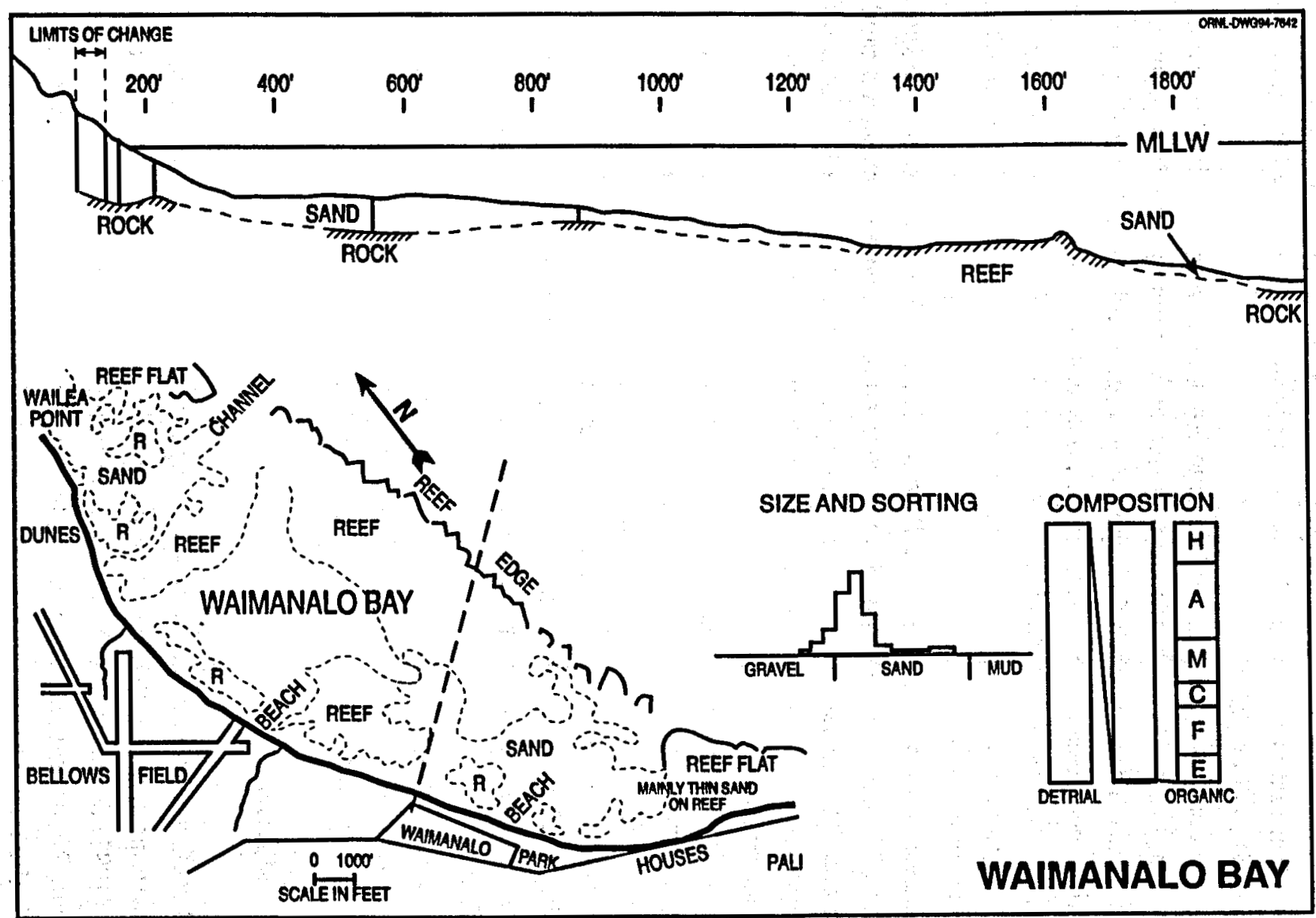

Fig. 12 Map and topographic profile of Waimanalo Bay. Source: Moberly 1963. 
highest reef diversity occurs at intermediate levels of physical stress or disturbance (Grigg and Maragos 1977; Connell 1978; Dollar 1982; Grigg 1983). The wave stress gradient results in a high diversity at an intermediate depth with lower diversity in rigorous shallower water and stable deeper water. The dominant coral species along the Kona coast of Hawaii are Porites compressa and $P$. lobata, which account for over $80 \%$ of the total bottom cover in some areas.

The study area includes reef communities at three locations - off Mahukona, in La Perousa Bay, and in Waimanalo Bay. Coral reefs are absent on the southern coast of Maui between Apole Point and Huakini Bay.

Off Mahukona, an area of high coral cover was delineated in a recent marine survey (unpublished data by PBR provided to Chalon International of Hawaii in 1990). Corals are the dominant component of the benthos in the nearshore area off Mahukona Harbor [ $<20 \mathrm{~m}$ ( $<65$ ft) depth], often exceeding $60 \%$ coverage, with the two principal species being Porites lobata and $P$. compressa. Other common Hawaiian corals were present in the survey. The coral community off Mahukona is similar to coral communities along the Kohala and Kona coast of the island of Hawaii. Fish communities identified in the survey were similar in composition and abundance to those reported from the western coast of the island of Hawaii (Hobson 1974).

The reefs off La Perousa Bay have not been surveyed, but are expected to be similar to reefs along the west coast of Maui. The coral reefs of Waimanalo Bay are well-developed and similar in composition to the more studied reefs of Kaneohe Bay.

Dredging and mechanical disturbance of reefs may impose chronic stress on the reef system. The stress would be the result of greater sediment loading (turbidity), reduced light penetration needed by autotrophic symbionts within the corals, and general decrease in water quality. However, Hawaiian reefs are quite tolerant of stresses (Kinsey 1987), and recovery such as has been seen with reefs at Kaneohe Bay after diversion of sewage is common (Smith et al. 1981).

\subsection{DEEPWATER COMMUNITY}

Deepwater habitats [200-1900 m (650-6000 ft) depths] harbor complex assemblages of microbes, meiofauna, macrofauna, and megafauna. The macroorganisms are dominated by depositfeeding and suspension-feeding polychaetes, crustaceans, echinoderms, and bivalves (Gage and Tyler 1991); foraminifera and bryozoans may also be abundant (Agegian et al. 1990). Because the marine study area traverses relatively high energy deep-sea habitats, the benthos are likely to be well adapted to water currents and mobile sediments. Commercially and recreationally exploited species living or feeding in deepwater habitats include the shrimp Heterocarpus laevigatus (King 1987; Tagami and Ralston 1988); only a small part of the study area in the Alenuihaha and Kaiwi Channels falls within the depth range of this shrimp [450-900 m (1475-2950 ft)] (King 1987). A variety of deepwater bottomfishes may inhabit or feed in these deep soft-sediment communities; 
however, only a small proportion of their total habitats lies within the study area. An insignificant portion of the commercially valuable fish species occur within the vicinity of the study area.

Several general characteristics of deep-sea benthos are particularly sensitive to environmental perturbations: deep-sea species typically have low metabolic, growth, and population recovery rates. These low rates are presumed to result primarily from low food inputs to deepwater habitats (e.g., Gage and Tyler 1991). In addition, because deep-sea benthos typically experience a very narrow range of environmental temperatures (Gage and Tyler 1991), they are likely to be very susceptible to thermal stress.

The only deepwater portion of the study area that has been surveyed for benthic resources is the Alenuihaha Channel. Auau Channel, Kolohi Channel, and crossing the Kaiwi Channel have not been surveyed, and no quantitative data are available to assess their deepwater communities. Based on dredge, photographic, and submersible studies of the deepwater benthic resources around the Hawaiian Islands, limited distributional and abundance information on selected macrofaunal groups are available. For fishes these sources include: Clarke (1972), Struhsaker (1973); for decapod crustaceans: Clarke (1972), and Titgen (1987); for gorgonians, Grigg and Bayer (1976); for megafauna; Chave and Jones (1991). The benthic megafauna in the Alenuihaha Channel are characterized by low abundance of organisms ( 0.09 individuals per square meter) with a patchy distribution pattern (Chave and Jones 1991). The species richness in the Alenuihaha Channel (75 reported species) is of the same order as species richness on other volcanic features such as seamounts in the north central Pacific, where about 128 species are reported (Wilson and Kaufmann 1987). A checklist of deepwater organisms from the Alenuihaha Channel is provided in Chave and Jones (1991). Calcareous organisms on mid-depth banks such as Penguin Bank off Molokai have been surveyed by Agegian and Mackenzie (1990).

Major beds of the precious black coral (Anthipathes dichotoma and A. grandis) occur in the Auau Channel at depths below $40 \mathrm{~m}$ (130 ft) (Grigg and Maragos 1974). Abundant colonies have also been observed off Kawaihae, Hawaii; Penguin Bank; and Koko Head, Oahu (Grigg and Bayre 1976). The Makapuu precious coral bed is located at a depth of about $400 \mathrm{~m}$ (1300 ft) off southeast Oahu and covers an area of approximately $2.6 \mathrm{~km}^{2}(1$ mile) with average densities of pink (Corallium secundum, $0.022 \pm 0.01$ colonies $/ \mathrm{m}^{2}$ ), gold (Gerardia sp., $0.0005 \pm 0.001$ colonies $/ \mathrm{m}^{2}$ ), and bamboo corals (Lepidisis olapa, $0.041 \pm 0.02$ colonies $/ \mathrm{m}^{2}$ ). These species occur on hard substratum swept free of sediment by strong bottom currents (Grigg 1988). At present only the black coral is harvested commercially from the main Hawaiian Islands (Grigg 1993).

\subsection{THREATENED AND ENDANGERED MARINE SPECIES}

\subsubsection{Marine Mammals}

Marine mammals reported from Hawaii are listed in Table 14. The Hawaiian monk seal, Monachus schauinslandi, and humpback whale, Megaptera novaeangliae, occur within the study 
Table 14. Species of marine mammals reported off Hawaii

\begin{tabular}{|c|c|c|}
\hline Species & Common name & Status ${ }^{a}$ \\
\hline \multicolumn{3}{|l|}{ Cetaceans } \\
\hline Balaenoptera physalus & Finback whale & $\mathbf{E}$ \\
\hline B. edenia & Bryde's whale & \\
\hline Beresa attenuata & Pygmy biller whale & . \\
\hline Globicephala & Pilot whale & \\
\hline \multicolumn{3}{|l|}{ macrorhynchus } \\
\hline Grampus griseus & Risso's whale & \\
\hline Kogia breviceps & Pygmy sperm whale & \\
\hline Megaptera novaeangliae & Humpback whale & $\mathbf{E}$ \\
\hline Mesoplodon desirostris & Densebeaked whale & \\
\hline Orcinus orca & Killer whale & \\
\hline Peponocephala electra & Melon-headed whale & \\
\hline Physeter catodon & Sperm whale & $\mathbf{E}$ \\
\hline Pseudorca crassidens & False killer whale & \\
\hline Stenella coenuleoalba & Stripped dolphin & \\
\hline S. attenuata & Spotted dolphin & \\
\hline S. longirostris & Spinner dolphin & \\
\hline Steno bredanensis & Rough-toothed dolphi & \\
\hline Tursiops gilli & Bottlenose dolphin & \\
\hline Ziphius carirostris & Goosebeaked whale & \\
\hline \multicolumn{3}{|l|}{ Pinnupeds } \\
\hline Monachus schauinslandi & Hawaiian monk seal & E \\
\hline
\end{tabular}

$$
\mathcal{E}=\text { endangered }
$$

The mont seal, Monachus schauinslandi, is endemic to Hawail. Breeding is restricted to the northwest Hawaiian Islands from Niboa Island to Kure Atol. Rare sightings of single individuals are possible in the study area (Van Torrenburg, Gilmartin, and Henderson 1993).

Sources: Payne 1981; Shallenberger 1981. 
area. Endangered cetaceans are rarely sighted in the vicinity of the major Hawaiian Islands with the exception of the humpback whale, Megaptera novaeangliae (Shallenberger 1977).

Humpback whales are annual migratory visitors to Hawaiian waters arriving in late November and remaining until May or June (Herman and Antinoja 1977; Baker and Herman 1981), with the major occurrence in Hawaiian waters between February and April (Herman 1993). Humpback whales migrate to the coastal areas of the Hawaiian Islands for calving, rearing, courtship, and feeding. In this area they appear to be limited to the 100-fathom [183-m (600-foot)] isobath and shallower waters. Tinney (1988) as cited in Nitta and Naughton (1989) concluded that whales in Hawaiian waters tend to favor depths of about 25 fathoms [ $46 \mathrm{~m}$ $(150 \mathrm{ft})]$; mothers and calves are frequently found at depths of 10 fathoms [18 $\mathrm{m}(60 \mathrm{ft})]$ or shallower. The area of greatest use in the Hawaiian waters is the four-island area of Maui, Molokai, Lanai, and Kahoolawe and the Penguin Bank, which extend approximately 25 nautical miles $(46 \mathrm{~km}$ ) to the southwest from western Molokai (Herman 1979; Nitta and Naughton 1989). The estimated size of the Hawaiian population of this species is $\mathbf{5 0 0}$ to $\mathbf{1 5 0 0}$ individuals (Darling, Gibson, and Silber 1983; Johnson and Wolman 1984; Darling and Morowitz 1986; Baker et al. 1986; Baker and Herman 1987). The island of Hawaii from Keahole Point north to Upolu Point is also heavily used. Documented sightings have occurred off Mahukona, Hawaii, and Pu'u Olai, Maui (near La Perouse Bay) (Maybaum 1989). There is no known incidence of humpback whales coming inshore at Mahukona, although humpbacks are known to pass the Mahukona area at some distance offshore (unpublished data by PBR provided to Chalon International of Hawaii in 1990). The area around the island of Oahu and the eastern and southwestern waters of the island of Hawaii receive substantially less usage (Nitta and Naughton 1989).

Cakving of humpback whales occurs between January and April. The estimated calving rate for the Hawaiian population is approximately 0.37 (Nitta and Naughton 1989). It is probable that mating occurs in or near the same waters as calving.

Humpback whales feed primarily on pelagic organisms of the coastal zone. These organisms include krill, along with schooling fishes such as herring, sand lance, capelin, juvenile salmonids, cod, walleye pollock, and anchovies. Whales feed from the surface down to about $150 \mathrm{~m}$ ( $90 \mathrm{ft}$ ) by skimming, lunge-feeding, and circular swimming and may feed as singular individuals or as cooperative groups. Humpback whales are believed not to feed to any significant extent during their residency in breeding waters (Dawbin 1966 as cited in Herman 1979).

Herman (1979) concluded that increased disturbance either by onshore construction activities, increased runoff and pollution, or possibly increased undersea ambient noise levels may cause cetaceans such as the humpback whale to relocate when disturbed. Use of the coastal habitats around the Hawaiian Islands by such activities as sea-bed mining, and oil and gas recovery, as well as nearshore pollution, ocean dumping, entanglement in fishing gear, and coastal-related development such as marinas, harbors, and resorts may increasingly subject humpback whales to disturbance. Habitat loss and modification can have a particularly acute impact in coastal wintering grounds associated with islands or island groups such as Hawaii, where 
preferred humpback whale habitat is limited and displacement into suboptimal areas may be forced by extensive human activities (Nitta and Naughton 1989).

Hawaiian monk seals are found primarily on the leeward or northwestern Hawaiian Islands. The numbers of this species decreased as the result of fur trade and human disturbance; the numbers of individuals continued to decrease starting with increased human presence on some of the leeward islands particularly the Midway Islands in the 1940s, and continued into the 1980s. During the late 1980s, the marked decline in births observed from 1981 to 1986 appears to have been reversed for the leeward islands, particularly for Kure Atoll (Van Toorenburg, Gilmartin, and Henderson 1993).

Hawaiian monk seals are very sensitive to human disturbance and generally disappear from areas frequented by humans, as is shown by the decreased numbers at Midway, Green Island, and Eastern Island (Kenyon 1981; Gerrodette and Gilmartin 1990). In response to disturbance, females may cease nursing pups, with a resulting high pup mortality. In addition to direct human disturbance, it is possible that monk seals are susceptible to ciguatoxin, which produces fish poisoning, or ciguatera, in man and other mammals. Ciguatera is thought to occur in the leeward Hawaiian Islands as the result of extensive harbor dredging and consequent reef destruction that takes place periodically at Midway (Kenyon 1981).

According to Eugene Nitta (personal communication with A. Jones, 1993), a few individual Hawaiian monk seals have taken up residence on Hawaii, Maui, Kauai, and Oahu. These individuals occur at regularly used sites, although their haul-out patterns can vary.

\subsubsection{Marine Reptiles}

Marine reptiles from Hawaii are listed in Table 15; all are either endangered or threatened. No nesting or basking of these marine turtles has been reported in the study areas on

Table 15. Species of endangered (E) or threatened $(T)$ marine reptiles reported off Hawaii

\begin{tabular}{lll}
\hline Species & Common name & Status \\
\hline Caretta caretta & Loggerhead sea turtle & $\mathbf{T}$ \\
Chelonia mydas & Green sea turtle & $\mathbf{E}$ \\
Dermochelys coriacea & Leatherback turtle & $\mathbf{E}$ \\
Eretmochelys imbricata & Hawksbill sea turtle & $\mathbf{E}$ \\
Lepidochelys olivacea & Olive ridley sea turtle & $\mathbf{T}$ \\
\hline
\end{tabular}


the islands of Hawaii, Maui, or Oahu. Because sea turtles use both the marine environment and the terrestrial environment, responsibility for their protection is shared by the National Marine Fisheries Service and the FWS. Both agencies were contacted for information on marine threatened and endangered species. Information on the sea turtles and recovery plans for the green and hawksbill turtles was provided by the National Marine Fisheries Service (NMFS 1992).

A small population of hawksbill turtles, Eretmochelys imbricata, occurs in the coastal waters of the eight main Hawaiian Islands. The leatherback turtle, Cermochelya coriacea, occurs in small numbers in the offshore waters, but it does not breed in the vicinity of the Hawaiian Islands. The olive ridley turtle, Lepidochelys olivacea, and the loggerhead turtle, Caretta ceretta, have been recorded, but only as rare visitors to Hawaiian waters (Balazs 1980).

The green turtle, Chelonia mydas, is the most abundant of the five turtle species occurring in the Hawaiian waters. The green turtle breeds almost exclusively in the uninhabited northwest Hawaiian Islands (Balazs 1980). During the nonbreeding season, green turtles occupy established foraging areas such as the ones off Mahukona, Hawaii, and Waimanalo, Oahu (Sinay-Friedman 1979) (Fig. 13). Sightings of the green turtle off Ahihi Bay, Maui, were made during a reconnaissance site investigation by A Jones during August 1993. The leatherback, Dermochellys coriacea, and olive ridley, Lepidochelys olivacea, both occur in Hawaiian waters but nest elsewhere.

Information from the green turtle recovery plan (NMFS 1992) states that this species may be found throughout the main Hawaiian Islands, usually associated with areas of abundant intertidal and subtidal macroalgae. At least $90 \%$ of all reproduction by green turtles in the Hawaiian Islands occurs at French Frigate Shoals in the northwestern Hawaiian Islands, with most of the remaining reproduction occurring on Laysan, Lisianski, and Pearl and Hermes reefs, in the northwestern Hawaiian Islands. In recent years, a very low level of nesting has occurred in the main Hawaiian Islands. The breeding season is from May through September although individuals may deposit their eggs and remain in the breeding area for only a few months. Female green turtles breed approximately every 2 years.

Green turtles reside in the nearshore habitat of the eight main, inhabited islands of Hawaii including Maui, Molokai, Oahu, and Hawaii. The nearshore habitat of these islands provides abundant algae and seagrass, which are the preferred food of this species, and favorable oceanic currents for transporting young turtles to the main islands for recruitment into coastal habitat. The nearshore benthic feeding areas of the main islands have depths of less than $10 \mathrm{~m}$ (30 ft), and frequently less than $3 \mathrm{~m}$ (10 ft) (Forsyth and Balazs 1989); the ocean increases greatly in depth a few kilometers from shore.

The primary threats to the conservation and recovery of the Hawaiian green turtle include loss of foraging habitat to nearshore development (e.g.., marina construction, artificial beach development, siltation from agricultural runoff, contamination of forage areas by toxic spills, resort development, and increased vessel traffic), ingestion of marine debris, incidental take in sport and 


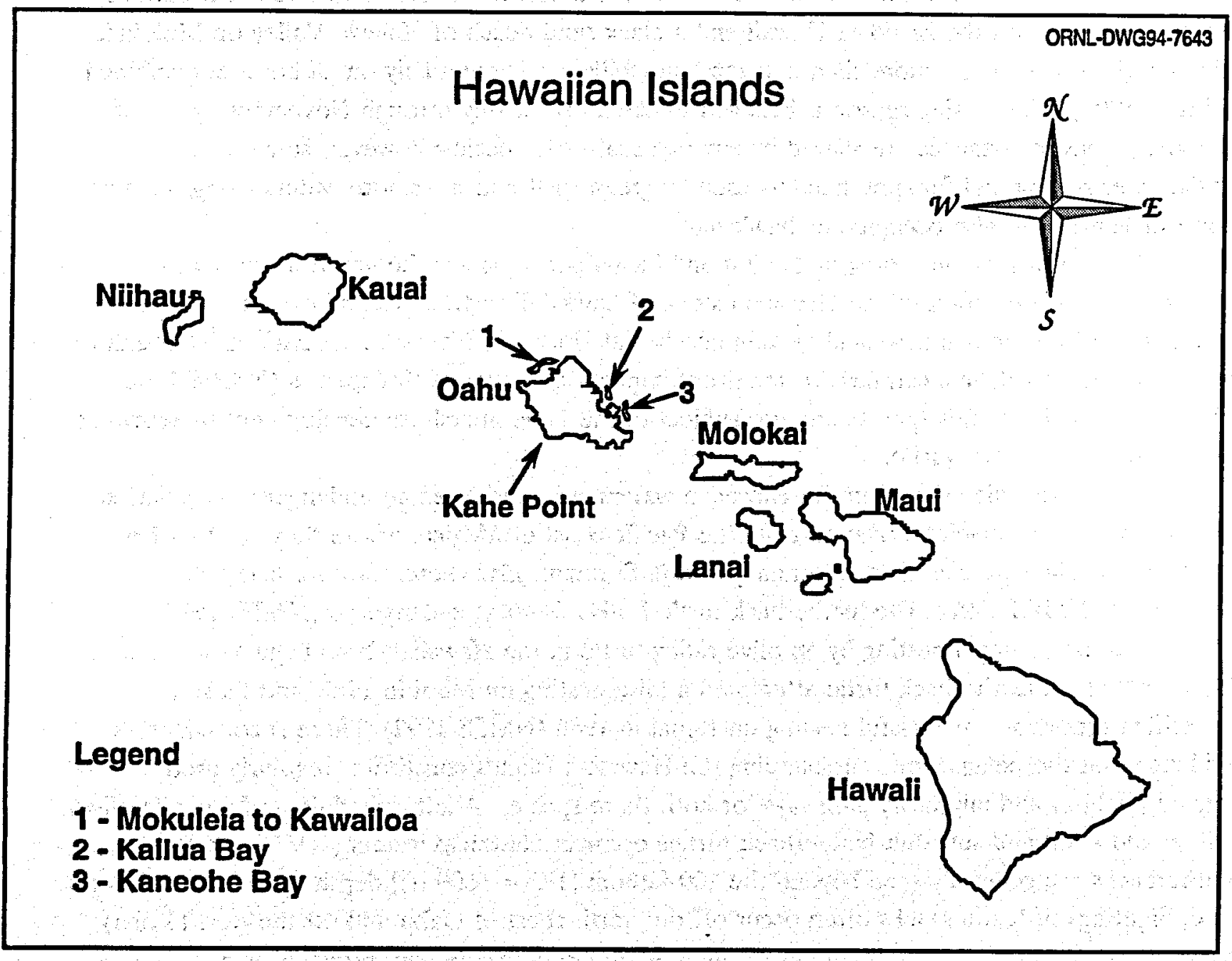

Fig. 13. Map of important foraging and basking areas for the Hawaiian green sea turtle, Chelonia mydas. Source: Sinay-Friedman 1979. 
commercial fisheries, poaching, and proliferation of fibropapillomas (tumors) of unknown cause (Forsyth and Balazs 1989).

The distribution of the hawksbill turtle, Eretmochelys imbricata, is limited to several nesting sites on Hawaii and Molokai. The primary nesting sites are on several small sand beaches along the east coast of island of Hawaii. Two of these sites (Halape and Apua Point) are at a remote location in the Hawaii Volcanoes National Park. The most consistently used sites are at Kamehame Point on the island of Hawaii and a black sand beach of Halawa Valley on Molokai. Overall, there may be no more than a dozen hawksbills nesting annually on all beaches combined (NMFS 1992). The nesting season is believed to extend from July through November. None of the known nesting beaches are shared by any two sea turtle species; however, some of the underwater resting and foraging habitats used by green turtles in nearshore waters along the east coast of Hawaii are also occupied by hawksbills.

Loss of nesting and foraging habitat and illegal poaching are the greatest threats to recovery and conservation of the Hawaiian stock of hawksbill turtles. Natural events, such as the loss of one of the known hawksbill nesting beaches at Harry $\mathrm{K}$. Brown Beach Park in Kalapana to a lava flow from Kilauea, can have a significant impact on habitat of this species (NMFS 1992). Foraging habitats for this species are also subject to the same nearshore development pressures as discussed for the green turtle.

The olive ridley turtles in the Hawaiian waters are considered an endangered population because of their probable derivation from the Pacific coast of Mexico, where they are listed as endangered. They are also listed as endangered in Surinam. Elsewhere, they are listed as threatened (NMFS 1992). The leatherback turtle is also listed as endangered (NMFS 1992).

The only known nesting by an olive ridley turtle in the Hawaiian Island chain occurred on Maui in 1985. A leatherback turtle attempted a false nesting on Maui in 1982, and there is an unverified report of a successful nesting on Kauai in 1986 (NMFS 1992). There is considerable evidence that the pelagic zone surrounding the Hawaiian Islands constitutes regularly used foraging habitat and migratory pathways for both these species. Adult, subadult, and juvenile olive ridleys and adult and subadult leatherback turtles occur in Hawaiian waters (NMFS 1992). The leatherbacks are generally seen beyond the 100-fathom [183-m (600-ft)] depth but within sight of land. Sightings of leatherbacks often occur off the north coast of Oahu and off the west (Kona) coast of the island of Hawaii. Sightings of olive ridleys are less common, probably as a consequence of their smaller size.

There are no federally listed benthic species inhabiting shallow-water soft-sediment communities or hard-bottom reef communities within the study area. In addition, no species of deepwater benthos have been identified as endangered or threatened. 


\section{REFERENCES}

Agegian, C., and F. Mackenzie. 1990. "Calcareous Organisms and Sedimént Mineralogy on a MidDepth Bank in the Hawaiian Archipelago," Pacific Science 43, 56-66.

Alongi, D. M. 1989a. "Benthic Processes Across Mixed Terrigenous-Carbonate Sedimentary Facies on the Central Great Barrier Reef Continental Shelf," Continental Shelf Research 9, 629-663.

Alongi, D. M. 1989b. "Ecology of Tropical Soft-Bottom Benthos: A Review with Emphasis on Emerging Concepts," Revista de Biologia Tropical 37, 85-100.

Alongi, D. M. 1990. "The Ecology of Tropical Soft-Bottom Benthic Ecosystems," Oceanography Marine Biology Annual Review 28, 381-496.

AOU (American Ornithologists' Union). 1983. Checklist of North American Birds, 6th ed., Allen Press, Lawrence, Kan.

Archer, K. M. 1983. Leaf litter decomposition in Hawaïan streams, M.S. Thesis, University of Hawaii, Manoa.

Atkinson, I A E 1970. "Successional Trends in the Coastal and Lowland Forest of Mauna Loa and Kilauea Volcanoes, Hawaii." Pacific Science 24, 387-400.

Baker, C., and L Herman. 1981. Migration and Local Movement of Humpback Whales (Megaptera novaeangliae) Through Hawaiian Waters," Canadian Journal of Zoology 59, $460-469$.

Baker, C. L., Herman, G. Kaufman, H. Winn, and J. Hall. 1986. Migratory Movement and Population Structure of Humpback Whales (Megaptera novaeangliae) in the Central and Eastern North Pacific," Marine Ecology Progress Series 31, 105-19.

Baker, C., and L. Herman. 1987. "Alternative Population Estimates of Humpback Whale (Megaptera novaeangliae) in Hawaiian Water," Canadian Journal of Zoology 65, 2818-21.

Balazs, G. H. 1980. Synopsis of Biological Data on the Green Turtle in the Hawaiian Islands. NOAA-TM-NMFS-SWFC-7, U.S. Department of Commerce National Oceanic and Atmospheric Administration Technical Memorandum, National Marine Fisheries Service.

Balder, A. P. 1992. Marine Atlas of the Hawaiian Islands, National Ocean Service. 
Berger, A. J., S. Conant, F. J. Radowsky, D. Mueller-Dombois, and F. G. Howarth. 1981. "Introduction: Community Structure and Niche Differentiation," pp. 213-30 in MuellerDombois, Bridges, and Carson.

Bostwick, J. M. 1982. Habitat loss and hybridization: The dual threat to the Koloa, Senior Honors Thesis, University of Hawaii, Honolulu.

Brock, R. 1990. Predevelopment Reconnaissance of the Marine Macrobiota and Water Quality Conditions Affronting the Proposed Development at Mahukona, North Kohala, Hawaï, prepared for Chalon International of Hawaii, Honolulu.

Brock, R. 1993. University of Hawaii, personal communication to V. R. Tolbert, Oak Ridge National Laboratory, October 2.

Brock, J., and R. Brock. 1974. The Marine Fauna of the Coast of Northern Kona, Hawaï. Sea Grant Advisory Report UNIHI-SEAGRANT-AR-74-02.

Brock, R. E., and J. E Norris. 1988. The Waikoloa Anchialine Pond Program second status report. Second Annual Report. Waikoloa Anchialine Pond Management Program.

Brown, B., M. Le Tissier, T. Scoffin, and A. Tudhope. 1990. "Evaluation of the Environmental Impact of Dredging on Intertidaly Coral Reefs at Ko Phuket, Thailand, Using Ecological and physiological parameters," Marine Ecology Progress Series 65, 273-81.

Byrd, G. V., R. A. Coleman, R. J. Shallenberger, and C. S. Arume. 1985. "Notes on the Breeding Biology of the Hawaiian Race of the American Coot," Elepaio 45(7), 57-63.

Campbell, J. F. 1983. Hawaï Deep-Water Cable Program, Phase II: At-Sea Route Surveys, Hawaii Institute of Geophysics 83-4, University of Hawaii, Honolulu.

Carpenter, F. L., and R. E MacMillen. 1973. Interactions Between Hawaïan Honeycreepers and Metrosideros Collina on the Island of Hawaii. Technical Report 33, Island Ecosystems IRP, U.S. International Biological Program.

Chai, D. K, L. W. Cuddihy, and C. P. Stone. 1989. An inventory and assessment of anchialine pools in Hawaï Volcanoes National Park from Waha'Ula to Ka'Aha, Puna and Ka'u, Hawaii, University of Hawaii at Maona, Honolulu.

Chave, E, and A. Jones. 1991. "Deep-Water Megafauna of the Kohala and Haleakala Slopes, Alenuihaha Channel, Hawaii," Deep-Sea Research 38, 781-803. 
Clark, J. 1985. Beaches of the Big Island. University of Hawaii Press, Honolulu.

Clarke, T. 1972. "Collections and Submarine Observations on Deep Benthic Fishes and Decapod Crustacea in Hawaii," Pacific Science 26, 310-17.

COE (U.S. Army Corps of Engineers). 1987. Corps of Engineers Wetlands Delineation Manual, Technical Report Y-87-1, Environmental Laboratory, U.S. Army Engineers Waterways Experiment Station, Vicksburg, Miss.

Coleman, R. A 1981. The Reproductive Biology of the Hawaiian Subspecies of the Black-Necked Stilt, Himantopus Mexicanus Knudseni, Ph.D. Thesis, Pennsylvania State University.

Conant, S. 1981. A Survey of the Waterbirds of Kawainui Marsh, prepared for Hawaii Department of Land and Natural Resources, Honolulu.

Connell, J. 1978. "Diversity in Tropical Rain Forests and Coral Reefs," Science 199, 1302-10.

Couret, C. L, Jr. 1976. The biology and taxonomy of a freshwater shrimp, Atya bisulcata Randall, endemic to the Hawaiian Islands, M.S. Thesis, Zoology Department, University of Hawaii at Manoa, Honolulu.

Cuddihy, L. W. 1989. "Vegetation Zones of the Hawaiian Islands," Pp. 27-37 in C. P. Stone and D. B. Stone, eds., Conservation Biology in Hawaii, Cooperative National Park Resources Studies Unit, University of Hawaii, Manoa.

Cuddihy, L. W., and C. P. Stone. 1990. Alteration of Native Hawaïan Vegetation, Cooperative National Park Resources Studies Unit, University of Hawaii, Manoa.

Darling, J., K Gibson, and G. Silber. 1983. "Observations on the Abundance and Behavior of Humpback Whales (Megaptera novaeangliae) off West Maui, Hawaii," pp. 201-22 in Communication and Behavior of Whales, AAAS Selected Symposium, ed. R. Payne, Westview Press, Colo.

Darling, J., and H. Morowitz 1986. "Census of 'Hawaiian' Humpback Whales (Megaptera novaeangliae) by Individual Identification," Canadian Journal of Zoology 64, 105-11.

Deacon, J. E, G. Kobetich, J. D. Williams, and S. Contreras. 1979. "Fishes of North America endangered, threatened, or of special concern." Fisheries 4:29-44. 
Devick, W. W. 1991. "Patterns of introductions of aquatic organisms to Hawaiian freshwater habitats," pp. 189-213 in New Directions in Research, Management, and Conservation of Hawaiian Stream Ecosystems, Proceedings 1990 Symposium on Freshwater Stream Biology and Fisheries Management, Honolulu.

DLNR (Hawaii Department of Land Natural Resources, Division of Forestry and Wildlife). 1993. State Waterbird Survey Data for Specific Wetland Sites on Maui and O'ahu, 1974-1993.

Dodd, C. K., Jr., G. E. Drewry, R. M. Nowak, J. M. Sheppard, and J. D. Williams. 1985. "Endangered and threatened wildlife and plants; review of vertebrate wildlife." Fed. Reg. 50:37957-37967.

Dollar, S. 1982. "Wave Stress and Coral Community Structure in Hawaii," Coral Reefs 1, 71-81.

Drake, D. R., and D. Mueller-Dombois. 1993. "Population Development of Rain Forest Trees on a Chronosequence of Hawaiian Lava Flows," Ecology 74, 1012-19.

Elliott, M. E., and E. M. Hall. 1977. Wetlands and Wetland Vegetation of Hawaï, U.S. Army Corps of Engineers, Pacific Ocean Division, Fort Shafter, Hawaii.

Engilis, A, Jr. 1988. Surveys and Inventories of Waterbirds in the State of Hawaii: A Ten-Year Trend Analysis, Pitt. Rob. Report W-18-R-12, R-III-A.

Engilis, A., Jr. and T. K Pratt. 1993. "Status and Population Trends of Hawaii's Native Waterbirds, 1977-1987," Wilson Bulletin 105(1), 142-58.

Evans, K, D. Woodside, and M. Bruegmann. 1994. A Survey of Endangered Waterbirds on Maui and O'ahu and Assessment of Potential Impacts to Waterbirds from the Proposed Hawai'i Geothermal Project Transmission Corridor. U.S. Fish and Wildife Service, Pacific Islands Office, Ecological Services, Honolulu (August).

Fisher, W. A., D. A. Davis, T. M. Sousa. 1966. Fresh-water springs of Hawaii from infrared images. U.S. Geological Survey Hydrologic Investigations Atlas HA-218.

Forsyth, R. G., and G. H. Balazs. 1989. Species Profiles: Life Histories and Environmental Requirements of Coastal Vertebrates and Invertebrates. Pacific Ocean Region. Report 1. Green Turtle, Chelonia mydas, National Marine Fisheries Service, Honolulu.

Franklin, J. F., and R. T. T. Forman. 1987. "Creating Landscape Patterns by Forest Cutting: Ecological Consequences and Principles," Landscape Ecology 1, 5-18. 
FWS (U.S. Fish and Wildlife Service). 1984. Hawaïan Hawk Recovery Plan, U.S. Fish and Wildlife Service, Portland, Ore.

FWS (U.S. Fish and Wildlife Service). 1985. Hawaiian Waterbirds Recovery Plan, U.S. Fish and Wildlife Service, Portland, Ore.

FWS (U.S. Fish and Wildlife Service). 1990a. Wetlands Losses in the United States, 1780s to 1980s, letter to T. E Dahl, March 21.

FWS (U.S. Fish and Wildlife Service). 1990b. Preliminary Project Proposal: Hawaïan Waterbirds Acquisition Program, U.S. Fish and Wildlife Service, Honolulu.

FWS (U.S. Fish and Wildlife Service). 1993. Revised Hawaïan Waterbirds Recovery Plan. unpublished draft.

Gage, J. D. and P. A. Tyler. 1991. Deep-Sea Biology: A Natural History of Organisms at the DeepSea Floor. Cambridge University Press, Cambridge.

Gagne, W. C., and C. C. Christensen. 1985. "Conservation Status of Native Terrestrial Invertebrates in Hawaii," pp. 105-26 in C. P. Stone and J. M. Scott, Hawaii's Terrestrial Ecosystems: Preservation and Management, Cooperative National Park Resources Study Unit, University of Hawaii at Manoa.

Gerrodette, T., and W. G. Gilmartin. 1989. Demographic Consequences of Changed Pupping and Hauling Sites on the Hawaiian Monk Seal," Conservation Biology 4, 423-29.

Grigg, R. 1983. "Community Structure, Succession and Development of Coral Reefs in Hawaii," Marine Ecology Progress Series 11, 1-14.

Grigg, R. 1988. "Recruitment limitation of a deep benthic hardbottom octocoral population in the Hawaiian Islands," Marine Ecology Progress Series 45, 121-26.

Grigg, R. 1993. "Precious coral fisheries of Hawaii and the U.S. Pacific Islands," Marine Fisheries Review 55, 47-57.

Grigg, R, and F. Bayre. 1976. "Present Knowledge of the Systematics and Zoogeography of the Order Gorgonacea in Hawaii," Pacific Science 30, 167-75.

Grigg, R., and J. Maragos. 1974. "Recolonization of Hermatypic Corals on Submerged Lava Flows in Hawaii," Ecology 55, 387-95. 
Hatcher, B. G., R. E. Johannes and A. I. Robertson. 1989. "Review of Research Relevant to the Conservation of Shallow Tropical Marine Ecosystems," Oceanography Marine Biology Annual Review 27, 337-414.

Herman, L, and R. Antinoja. 1977. "Humpback Whales in the Hawaiian Breeding Waters: Population and Pod Characteristics," Science Report of the Whales Research Institute 29, 59-85.

Herman, L. 1979. "Humpback Whales in Hawaiian Waters: A Study in Historical Ecology," Pacific Science 33, 1-15.

Herman, L. 1993. University of Hawaii, personal communication to A. Jones, September.

Hobson, E S. 1974. "Feeding Relationships of Teleostean Fishes on Coral Reefs in Kona, Hawaii," Fisheries Bulletin 72, 915-1001.

Hodges, C. S., T. Adee, J. D. Stein, H. B. Wood, and R. D. Doty. 1986. Decline of Ohia (Metrosideros polymorpha) in Hawaii: A Review, Exp. Sta., Gen. Tech. Rep. PSW-86U.S, Department of Agriculture, Forest Service Pacific Southwest Forest Rangers.

Howarth, F. G. 1981. "Community Structure and Niche Differentiation in Hawaiian Lava Tubes," pp. 318-36 in D. Mueller-Dombois, Bridges, and Carson.

Howarth, F. G., and W. P. Mull. 1992. Hawaiian Insects and Their Kin, University of Hawaii Press, Honolulu.

Huenneke, L. F, and P. M. Vitousek. 1992 "Seedling and Clonal Recruitment on the Invasive Tree Psidium cattleianum: Implications for Management of Native Hawaiian Forests," Biology Conservation 53, 199-211.

Ingebritsen, S. E., and M. A. Scholl. 1993. "Annotated Bibliography: Hydrogeology of Kilauea Volcano, Hawaii," U.S. Geological Survey Open-File Report 93-551-D, Menlo Park, California.

Jacobi, J. D. 1989. Vegetation Maps of the Upland Plant Communities on the Islands of Hawaii, Maui Moloka'i and Lana'i. Technical Report 68, Cooperative National Park Resources Studies Unit, University of Hawaii, Manoa. 
Jacobi, J. D. 1990. Distribution Maps, Ecological Relationships, and Status of Native Plant Communities on the Island of Hawai'i, Ph.D. Dissertation, University of Hawaii at Manoa, Honolulu.

Jacobi, J. D., M. Reynolds, G. Ritchotte, B. Nielsen, A. Viggiano, and J. Dwyer. 1994. Surveys of Forest Bird Populations Found in the Vicinity of Proposed Geothermal Project Subzones in the District of Puna, Hawai'i. U.S. Fish and Wildife Service Report, Hawai'i Research Station, Hawai'i National Park, Hawaii.

Jacobi, J. D., et al. 1994. Vegetation Component of Geothermal EIS Studies: Introduced Plants, Ecosystem Stability, and Geothermal Development. U.S. Fish and Wildlife Service, Pacific Islands Office, Ecological Services, Honolulu.

Johnson, J., and A. Wolman. 1984. "The Humpback Whale, Megaptera novaeangliae," Marine Fishery Reviews 46, 30-37.

Kay, E., L. Lau, E. Stroup, S. Dollar, D. Fellows, and R. Young. 1977. Hydrologic and Ecologic Inventories of the Coastal Waters of West Hawaï, Technical Report 105, Water Resources Research Center, University of Hawaii, Honolulu.

Kenyon, K W. 1981. "The Hawaiian Monk Seal; An Endangered Marine Mammal," Water Spectrum, Spring, 1-6.

Kimura, B. Y., and K. M. Nagata. 1980. Hawaï's Vanishing Flora, Oriental Publishing Co., Honolulu, 1980.

King, M. 1987. "Distribution and Ecology of Deep-Water Caridean Shrimps (Crustacea; Natantia) Near Tropical Pacific Islands," Bulletin of Marine Science 41, 192-203.

Kinsey, D. W. 1987. "Effects of Run-Off, Siltation and Sewage," pp. 1-10 in Fringing Reef Workshop: Science Industry and Management, Great Barrier Reef Marine Park Authority, Workshop Series 9.

Kinzie, R. A III. 1988. "Habitat utilization by Hawaiian stream fishes with reference to community structure in oceanic island streams." Environ. Biol. Fish 22:179-92.

Kinzie, R. A III. 1990. Species profiles: Life histories and environmental requirements of coastal vertebrates and invertebrates, Pacific Ocean Region; Report 3. Amphidromous macrofauna of island streams. Technical Report EL-89-10, U.S. Army Engineer Waterways Experiment Station, Vicksburg, Mississippi. 
Kirch, P. V. 1982. "The Impact of Prehistoric Polynesians on the Hawaiian Ecosystem," Pacific Science $36(1), 1-4$.

Kjargaard, M. S. 1991. An Avifaunal Survey of the Proposed Water Pipeline South Hilo to South Kahala and Hamakua Districts, Hawaii Island, Hawaii. Appendix F in Water Resource Development and Across-Island Transmission, Island of Hawaii, Hawaii Department of Land and Natural Resources, State of Hawaii, Honolulu.

Krasnick, G., and J. Mansur. 1987. Hawaï Deep Water Cable Program, Phase II-C, Task 1 Environmental Assessment, prepared for Hawaiian Electric Company, Inc., and the State of Hawaii, Honolulu.

Lamoureux, C. H., W. P. Char, A. J. Berger, L. W. Cuddihy, M. S. Kjargaard, R. L. Stemmermann, and W. A. Whistler. 1985. Puna Geothermal Area Biotic Assessment: Puna District, County of Hawaii, Department of Botany, University of Hawaii at Manoa, Honolulu.

Little, E. L., Jr., and R. G. Skolman. 1989. Common Forest Trees of Hawaï, Agriculture Handbook 679, U.S. Department of Agriculture, Forest Service, Washington, D.C.

Maciolek, J. A. 1972. "Macrobrachium lar as a culture prawn in the tropical insular." Pacific. Proc. West. Assn. Game Fish Commrs. 52:550-58.

Maciolek, J. A. 1983. "Distribution and biology of Indo-Pacific insular hypogeal shrimps." Bull. Mar. Sci 33:606-18.

Maciolek, J. A. 1986. "Environmental Features and Biota of Anchialine Pools on Cape Kona'u, Maui, Hawaii," Stygologia 2(112), 119-29.

Makai Ocean Engineering, Inc., E. K. Noda and Associates, Inc., and Evans Hamilton, Inc. 1990. Hawaï Deep Water Cable Program: At-Sea Test Report, report prepared for Hawaiian Dredging and Construction Co.

Maragos, J. E. 1977: "Order Scleractinia" pp. 158-241 in Reef and Shore Fauna of Hawaii Section 1: Protoza through Ctenophore, ed. D. M. Devaney and L. G. Eldredge, B. P. Bishop Museum Special Publication 64(1).

Maybaum, H. 1989. Effects of a 3.3-kHz Sonar System on Humpback Whales, Megaptera novaeangliae, in Hawaiian Waters, M.S. Thesis, University of Hawaii, Honolulu. 
McEldowney, H.; and F. D. Stone. 1991. Survey of Lava Tubes in the Former Puna Forest Reserve and on Adjacent State of Hawaii Lands, State Historic Preservation Division, Department of Land and Natural Resources, State of Hawaii, Honolulu.

Medeiros, A C., Jr., L. L. Loope, and R. A. Holt. 1986. Status of Native Flowering Plant Species on the South Slope of Haleakala, East Maui, Hawaii, Technical Report 59, Cooperative National Park Resources Studies Unit, Hawaii.

Moberly, R., Jr. 1963. Coastal Geology of Hawaii, HIG Technical Report 41, Hawaii Institute of Geophysics, Honolulu.

Mueller-Dombois, D. 1986. "Perspectives for an Etiology of Stand-Level Dieback, Annual Review of Ecology and Systematics 17, 221-43.

Mueller-Dombois, D. 1990. "Forest Decline and Soil Nutritional Problems in Pacific Areas," Water, Air, and Soil Pollution 54, 195-207.

Mueller-Dombois, D., K. W. Bridges, and H. L. Carson, (eds). 1981. Island Ecosystems, Hutchinson Ross Pub., Stroudsburg.

Mueller-Dombois, D., R. G. Gooray, J. E. Maka, G. Spatz, W. C. Gagne, F. G. Howarth, J. L. Gressitt, G. A. Samuelson, S. Conant, and P. Q. Tomich. 1981. "Structural Variation of Organism Groups Studied in the Kilauea Forest," pp. 231-317 in Mueller-Dombois, Bridges, and Carson.

Munro, G. C. 1960. Birds of Hawaii, Charles E. Tuttle Co., Rutland, Vt.

Nitta, E. T. 1993. National Marine Fisheries Service, Long Beach, Calif, personal communication to J. C. Stroud, U.S. Department of Energy, Oak Ridge, Tenn., October 5.

Nitta, E T., and J. J. Naughton. 1989. "Species Profile: Life histories and environmental requirements of coastal vertebrates and invertebrates," Pacific Ocean Region, Report 2. "Humpback Whale, Megaptera novaeangliae" Southwest region, National Marine Fisheries Service, National Oceanic and Atmospheric Administration, Honolulu.

NMFS (National Marine Fisheries Service). 1992. Interim Recoveny Plan for Hawaiian Sea Turtles, The Hawaiian Sea Turtle Recovery team, Southwest Fisheries Science Center, NOAA, Honolulu. 
Okahara and Associates, Inc. 1992. Water Resource Development and Across-Island Transmission, Island of Hawaï, revised draft environmental impact statement, prepared for Department of Land and Natural Resources, State of Hawaii, Honolulu.

Olson, S. L. and H. F. James. 1982. "Prodromus of the Fossil Avifauna of the Hawaiian Islands," Smithsonian Contributions to Zoology 365, 1-59.

O'Neill, R. V., J. R. Krummel, R. H. Gardner, S. Sugihara, B. Jackson, D. L. Angelis, B. T. Milne, M. G. Turner, B. Zygmunt, S. W. Christensen, V. H. Dale, and R. L. Graham. 1988. "Indices of Landscape Pattern," Landscape Ecology 1, 153-62.

Paton, P. W. C. 1981. "The Koloa (Hawaiian Duck) on the Island of Hawaii," Elepai 41(12), 131-33.

Payne, S. F., and E O. Hartwig. 1981. The Ecology of Hawaïan Marine Mammals Emphasizing the Impact of Ocean Thermal Energy Conversion (OTEC) on Endangered Species, LBL14555, Lawrence Berkeley Laboratory, University of California, Berkeley.

Reed, M., and L. Oring. 1994. "Status of the Hawaiian Stilt," Proceedings of Western Section of the Wilderness Society, in press.

Reynolds, M., G. Ritchotte, A. Viggiono, J. Dwyer, B. Nielson, and J. D. Jacobi. 1994a. Surveys of the Distribution of Seabirds Found in the Vicinity of Proposed Geothermal Projects Subzones in the District of Puna, Hawaï, U.S. Fish and Wildlife Service, Hawaii National Park, Hawaii.

Reynolds, M., G. Ritchotte, A. Viggiano, J. Dwyer, B. Nielsen, and J. D. Jacobi. 1994b. Surveys of Distribution and Abundance of the Hawaiian Hawk within the Vicinity of Proposed Geothermal Project Subzones in the District of Puna, Hawai'i. U.S. Fish and Wildife Service, Pacific Islands Office, Ecological Services, Honolulu.

Reynolds, M., G. Ritchotte, J. Dwyer, A. Viggiano, B. Nielsen, and J. D. Jacobi. 1994c. Surveys on the Distribution and Abundance of the Hawaiian Hoary Bat (Lasiurus cinereus semotus) in the Vicinity of Proposed Geothermal Project Subzones in the District of Puna, Hawai'i. U. S. Fish and Wildlife Service, Pacific Islands Office, Ecological services, Honolulu.

Ripperton, J. C., and E. Y. Hosaka. 1942. Vegetation Zones of Hawä̈, University of Hawaii Agricultural Experiment Station Bulletin 89, University of Hawaii, Manoa. 
Roberts, D. 1994. Hawaii Heritage Program, Honolulu, personal communication to V. R. Tolbert, Oak Ridge National Laboratory, March 23.

Rock, J. F. 1913. The Indigenous Trees of Hawai'i, privately published, Honolulu.

Schwartz, C. W., and E. R. Schwartz. 1949. The Game Birds in Hawaï, Division of Fish and Game and Board Commission of Agriculture and Forestry, Honolulu.

Scott, J. M., S. Mountainspring, F. L. Ramsey, and C. B. Kepler. 1986. Forest Bird Communities of the Hawaiian Islands: Their Dynamics, Ecology, and Conservation, Studies in Avian Biology No. 9, Cooper Ornithological Society, Department of Biology, University of California, Los Angeles.

Shallenberger, R. J. 1977. An Omithological Survey of Hawaiian Wetlands. Ahuimanu Productions Contract DACW 87-77-C-0036, U.S. Army Engineering District, Honolulu.

Sinay-Friedman, L 1979. Supplement to the Draft Environmental Impact Assessment, Ocean Thermal Energy Conversion (OTEC) Preoperational Ocean Test Platform. Prepared for U.S. Department of Energy (Contract No. 55-00601).

Smith, S. V., W. J. Kimmerer, E. A. Laws, R. E. Brock, and T. W. Walsh. 1981. "Kaneohe Bay Sewage Diversion Experiment: Prespectives on Ecosystem Responses to Nutritional Perturbation," Pacific Science 35, 279-395.

Sorey, M. L and Colvard, E. M. 1994. Potential for Impacts from the Hawaï Geothermal Project on Ground-Water Resources on the Island of Hawaii," USGS-WRI-943-4028, U.S. Geological Survey, Menlo park, California.

Staub, W. P. 1994. Environmental Resources of Selected Areas of Hawaii: Groundwater in the Puna District of the Island of Hawaii, ORNL/TM-12858, Oak Ridge National Laboratory, Oak Ridge, Tenn.

Stone, C. P. 1992. "Hilo to Waimea Pipeline Environmental Impact Study: Lava Tubes" Appendix $E$ in Okahara and Associates.

Stone, C. P., and J. M. Scott 1985. Hawaï's Terrestrial Ecosystems: Preservation and Management, Cooperative National Park Resources Study Unit, University of Hawaii at Manoa, Honolulu. 
Stone, C. P., C. W. Smith, and J. T. Tunison. 1993. Alien Plant Invasions in Native Ecosystems of Hawaii: Management and Research, Cooperative National Park Resources Studies Unit, University of Hawaii, Manoa.

Stone, C. P., and D. B. Stone, eds. 1989. Conservation Biology in Hawaï, Cooperative National Park Resources Studies Unit, University of Hawaii, Manoa.

Struhsaker, P. A. 1973. Contribution to the Systematics and Ecology of Hawaiian Bathyal Fishes, Ph.D. Dissertation, University of Hawaii, Honolulu.

Tagami, D. T., and S. V. Ralston. 1988. An Assessment of Exploitable Biomass and Projection of Maximum Sustainable Yield for Heterocarpus Laevigatus in the Hawaiian Islands, H-88-14, Southwest Fisheries Center, National Marine Fisheries Service, National Oceanic and Atmospheric Administration, Honolulu.

Takasaki, K. J. 1993. "Ground Water in Kilauea Volcano and Adjacent Areas of Mauna Loa Volcano, Island of Hawaii," U.S. Geological Survey Open-File Report 93-82, U.S. Geological Survey, Honolulu.

Titgen, R. 1987. "New Decapod Records from the Hawaiian Islands," Pacific Science 41, $141-47$.

TNCH (The Nature Conservancy of Hawaii). 1987. Biological Overview of Hawaï's Natural Area Reserves System. Hawaii Heritage Program, prepared for Hawaii Department of Land National Resources, Honolulu.

TNCH (The Nature Conservancy of Hawaii). 1989a. State of Hawaii, Natural Area Reserves System Biological Resources and Management Priorities: Appendices. Hawaii Heritage Program, The Nature Conservancy of Hawaii, Honolulu.

TNCH (The Nature Conservancy of Hawaii). 1989b. Sensitive Biological Resources Element Occurrence Reconds, Hawaii, Maui, The Nature Conservancy of Hawaii, Honolulu.

TNCH (The Nature Conservancy of Hawaii). 1989c. Natural Community Description, The Nature Conservancy of Hawaii, Honolulu.

TNCH (The Nature Conservancy of Hawaii). 1991. "Ecosystem Loss in Hawaii: Maps Depicting Native Ecosystems before and After 1500 Years of Human Habitat," unpublished map series for Hawaii, Maui, Lana'i, Moloka'i, O’ahu, and Kaua'i, Hawaii Heritage Program, The Nature Conservancy of Hawaii, Honolulu. 
TNCH (The Nature Conservancy of Hawaii). 1993a. Occurrence Record for Hawaiian Stilts at Ahihi-Kona'u Natural Area Reserve. Hawaii Heritage Program, The Nature Conservancy of Hawaii, Honolulu.

TNCH (The Nature Conservancy of Hawaii). 1993b. "Key to Map Reference Numbers for Kaup, Luala'ilua Hills, and Măkena," USGS 7.5-minute topographic quadrangle maps, Hawaii Heritage Program, The Nature Conservancy of Hawaii, Honolulu.

USAF (U.S. Air Force). 1975a. Fish and Wildife Plan for Bellows Air Force Station, Oahu, Hawaï, Bellows Air Force Station, Oahu.

USAF (U.S. Air Force). 1975b. Environmental Assessment for Fish and Wildlife Management Plan (1975-1980), Bellows Air Force Station, Oahu.

Van Riper, S. G., and C. Van Riper III. 1982. A Field Guide to the Mammal in Hawaii. Oriental Publishing Co., Honolulu.

Van Torrenburg, R. A, W. G. Gilmartin, and J. R. Henderson. 1993. "Composition of the Hawaiian Monk Seal Population at Kure Atoll, 1990," Pacific Science 47, 211-14.

Vitousek, P. M. 1986. "Biological Invasions and Ecosystem Properties: Can Species Make a Difference?" pp. 163-78 in Ecology of Biological Invasions of North America and Hawaii, Springer-Verlag, New York.

Wagner, W. L., D. R. Herbst, and R. S. N. Yee. 1985. "Status of the Native Flowering Plants of the Hawaiian Islands," pp. 23-74 in C. P. Stone and J. M. Scott, Hawaii's Terrestrial Ecosystems: Preservation and Management, Cooperative National Park Resources Study Unit, University of Hawaii at Manoa, Honolulu.

Wakeley, J. S., S. W. Sprecher, and R. Lichvar. 1994. Results of Preliminary Reconnaissance Trip to Determine the Presence of Wetlands in Wet Forest Habitats on the Island of Hawaii as part of the Hawaii Geothermal Project, October 1993. CEWES-ER-W, U.S. Army Engineer District, Honolulu (May).

Wenner, A.M., R. Ricard, and J. Dugan. 1987. "Hippid Crab Population Structure and Food Availability on Pacific Shorelines," Bulletin of Marine Research 41, 221-33. 
Wester, L. 1993. "Origin and Distribution of Adventive Alien Flowering Plants in Hawaii," pp. 99-154 in C. P. Stone, C. W. Smith, and J. T. Tunison, Alien Plant Invasions in Native Ecosystems of Hawaï: Management and Research, Cooperative National Park Resources Studies Unit, University of Hawaii, Manoa.

Wilson, S. B., and A. H. Evans. 1990. Aves Hawaüiensis: The Birds of the Sandwich Islands, R. H. Porter, London.

Wilson, R., Jr., and R. Kaufman. 1987. "Seamount Biota and Biogeography," pp. 355-77 in B. Keating, P. Fryer, R. Batzia, and G. Boehlert, American Geophysical Union Monograph.

Wong, D. C. L. 1975. Algae of the Anchialine Pools at Cape Kana'u, Maui, and Aspects of the Trophic Ecology of Halocaridina nubra Holthuis (Decapoda, Atyidae), M.S. Thesis, University of Hawaii at Manoa, Honolulu. 


\section{LIST OF PREPARERS}

Oak Ridge National Laboratory

Robert M. Reed, Research Staff, Energy Division

Contribution: Project management and review

Education: Ph.D. Plant Ecology, 1969, Washington State University

Virginia R. Tolbert, Research Staff, Environmental Sciences Division

Contribution: Aquatic ecology

Education: Ph.D., Ecology, 1978, University of Tennessee-Knoxville

Carl C. Trettin, Research Staff, Environmental Sciences Division*

Contribution: Terrestrial ecology

Education: Ph.D. Ecology, 1991, North Carolina State University

Private Consultants

The following people prepared contributions as indicated under individual subcontracts with Oak Ridge National Laboratory:

Anthony $T$. Jones

Technical contribution: Marine resources of deep ocean

Education: Ph.D. Oceanography, 1993, University of Hawaii at Manoa

Professional affiliation: Oceanus Flotation Technologies, Inc., Vancouver, British Columbia

Adrianus J. Kalmijn

Technical contribution: Electromagnetic effects on marine mammals

Education: Ph.D., Biology and Physics, 1963, University of Utrecht, The Netherlands

Professional affiliation: Scripts Institute of Oceanography, University of California, San Diego

Craig R. Smith

Technical contribution: Marine resources of the coastal zone and review of marine resources materials

Education: Ph.D., Biological Oceanography, 1983, University of California, San Diego, Scripts Institution of Oceanography

Professional affiliation: Department of Oceanography, University of Hawail at Manoa, Honolulu, Hawaii

*Current Address:

U. S. Forest Service

Center for Forested Wetlands Research

Southeastern Forest Experiment Station

Charleston, South Carolina 

ORNL/TM-12863

\section{INTERNAL DISTRIBUTION}

$\begin{array}{ll}\text { 1. } & \text { T. J. Blasing } \\ \text { 2. } & \text { G. E. Courville } \\ \text { 3. } & \text { C. E. Easterly } \\ \text { 4. } & \text { F. M. Glenn } \\ \text { 5. } & \text { D. A. Lombardi } \\ \text { 6. } & \text { C. H. Petrich } \\ \text { 7. } & \text { H. D. Quarles, III } \\ \text { 8-17. } & \text { R. M. Reed } \\ \text { 18. } & \text { D. E. Reichle } \\ \text { 19. } & \text { J. W. Saulsbury } \\ \text { 20. } & \text { A. C. Schaffhauser }\end{array}$

\author{
21. S. M. Schexnayder \\ 22. R. B. Shelton \\ 23. B. M. Sorensen \\ 24. W. P. Staub \\ 25. V. R. Tolbert \\ 26. A. K. Wolfe \\ 27-28. Laboratory Records \\ 29. Laboratory Records-RC \\ 30. Document Reference Section \\ 31. Central Research Library \\ 32. ORNL Patent Section
}

\section{EXTERNAL DISTRIBUTION}

33. Office of the Assistant Manager for Energy Research and Development, Department of Energy, Oak Ridge Operations, P. O. Box 2001, Oak Ridge, TN 37831

34. Andrea Campbell, Department of Energy, Oak Ridge Operations, Bldg. 2714-J, SE-311, Oak Ridge, TN 37831-8739

35. Virginia H. Goldstein, Director, Hawaii County Planning Commission, 25 Aupuni Street, Room 109, Hilo, HI 96721

36. Hugo Huntzinger, Superintendent, Hawaii Volcanoes National Park, P. O. Box 52, Hawaii Volcanoes National Park, HI 96718-0052

37. Maurice H. Kaya, Energy Program Administrator, Department of Business, Economic Development \& Tourism, 335 Merchant Street, Suite 108, Honolulu, HI 96813

38. Allan J. Jelacic, Office of Renewable Energy Conversion (EE-12), U.S. Department of Energy, Forrestal Building, 1000 Independence Ave. SW, Washington, DC 20585

39. Anthony T. Jones, 1000 Pope Road, Honolulu, Hawaii $96822-2336$

40. Adrianus J. Kalmijn, 1064 California Street, Encinitas, CA 92024

41-45. Roland R. Kessler, Director, Office of Renewable Energy Conversion (EE-12), U.S. Department of Energy, Forrestal Building, 1000 Independence Ave. SW, Washington, DC 20585

46. Mike Lee, Chief, Operations Division, Honolulu Engineer District, Building 230, Fort Shafter, HI 96858-5440

47. John Naughton, Pacific Area Office, National Marine Fisheries Service, National Oceanic and Atmospheric Administration, 2570 Dole Street, Honolulu, HI $96822-2396$

48. Manuel Nathenson, U.S. Geological Survey, Geologic Division, Branch of Volcanic and Geothermal Processes, 345 Middlefield Road, M/S 910, Menlo Park, CA 94025

49. Craig Smith, 1271 Ulunahele Street, Kailna, Hawaii 96734

50. Robert Smith, Director, Pacific Island Office, U.S. Fish and Wildlife Service, Prince Kuhio Building, Room 6307, 300 Ala Moana Boulevard, Honolulu, HI 96850

51-55. Judith C. Stroud, ER-10, Department of Energy, Oak Ridge Operations Office, P. O. Box 2001, Oak Ridge, TN 37831-6600

56. Carl C. Trettin, Center for Forested Wetland Research, Southeastern Forest Experiment Station, 2730 Savannah Highway, Charleston, SC 29414

57. Lillian D. Trettin, 712 Wakendaw Blvd., Mount Pleasant, South Carolina 29464

58-59. Office of Scientific and Technical Information, P. O. Box 62, Oak Ridge, TN 37831 